UNIVERSIDADE DE SÃO PAULO

INSTITUTO DE PSICOLOGIA

Stella Pereira de Almeida

\title{
PRIMEIRO PERFIL DO USUÁRIO DE “ÊXTASE” (MDMA) EM SÃO PAULO
}

Dissertacao apresentada ao Instituto de Psicologia da Universidade de São Paulo como parte dos requisitos para a obtenção do título de Mestre em Psicologia.

Área de Concentração: Psicologia Experimental.

Orientadora: Maria Teresa Araujo Silva

São Paulo

2000 
Ficha Catalográfica preparada pelo Serviço de Biblioteca e Documentação do Instituto de Psicologia da USP

Almeida, S. P. de.

Primeiro perfil do usuário de "Êxtase” (MDMA) em São Paulo / Stella Pereira de Almeida;. --São Paulo, 2000. - 80 p.

Dissertaçao (Mestrado) - Instituto de Psicologia da Universidade de São Paulo. Departamento de Psicologia Experimental.

Orientador: Maria Teresa Araujo Silva

1. Êxtase 2. Drogas 3. Serotonina 4. Sistema Nervoso Central 5. Redução de dano 6. Inventário de Depressão de Beck 7. Inventário de Ansiedade Traço-Estado I. Título. 
PRIMEIRO PERFIL DO USUÁRIO DE “ÊXTASE” (MDMA) EM SÃO PAULO

Candidata: Stella Pereira de Almeida

Orientadora: Maria Teresa Araújo Silva

BANCA EXAMINADORA:

Nome e assinatura

Nome e assinatura

Nome e assinatura

Nome e assinatura

Nome e assinatura

Dissertação defendida e aprovada em : 
Para Beto, Matheus e Joana. 


\section{AGRADECIMENTOS}

À Teresa por ter acreditado no projeto e por sua orientação em todas as etapas.

À Raquel por estar sempre perto e disponível, ate quando morava na Itália.

Aos meus pais, Lorenzo e Carmita, por ajudarem sempre e de tantas formas.

À Paula por suas contribuições e indicações.

Ao Dr. Hermano Tavares por sugerir e ceder a escala de avaliação de Impulsividade.

À Dra. Clarice Gorentein por sugestões relativas as escalas empregadas e no exame de qualificação.

À Dra. Emma Otta pelas sugestões no exame de qualificação.

À todos do laboratório, Cilene, Mirian, Lugui, Fabio, Juliana, Edi, que me esclareceram duvidas sempre que precisei.

Ao CNPq e à CAPES pelo apoio financeiro. 
“ Na pista a massa dança em comunhão ao ritmo de uma única batida, uma única música, uma droga, uma única alma coletiva. O DJ é o novo messias; amusica a palavra de Deus. O vinho dos cristãos foi substituído pelo ecstasy e a iconografia dos vitrais pelos monitores de televisão.”

In Amor, curiosidade, Prozac e dúvidas. Lucia Etxebarría, 1997.

“NOITE. Todo estado que suscita no sujeito a metáfora da obscuridade (afetiva, intelectual, existencial) na qual ele se debate ou se acalma.”

In Fragmentos de um discurso amoroso Roland Barthes, 1977. 


\section{SUMÁRIO}

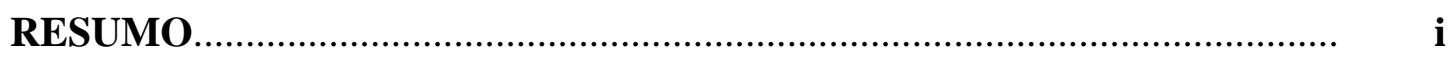

ABSTRACT

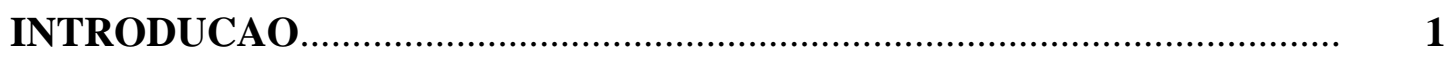

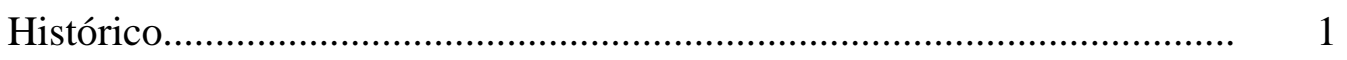

Uso no Brasil..................................................................................... 5

Classificação e composição química............................................................ 6

Efeitos psicológicos e somáticos.............................................................. 9

Toxicidade e complicações clínicas......................................................... 10

Mecanismo de ação no Sistema Nervoso Central..................................... 14

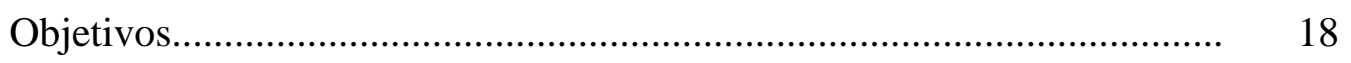

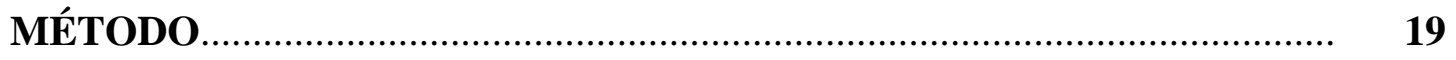

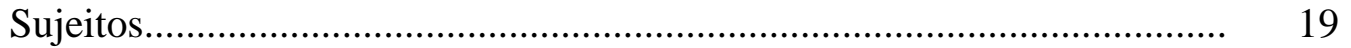

Instrumento....................................................................................... 21

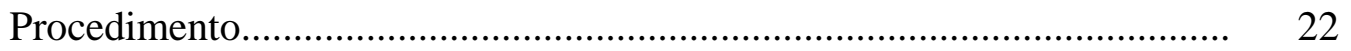

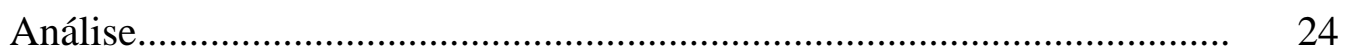

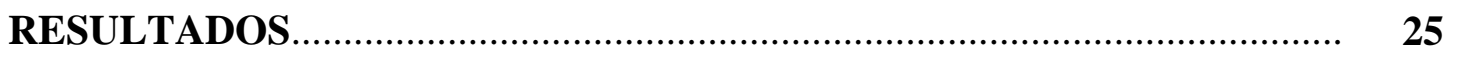

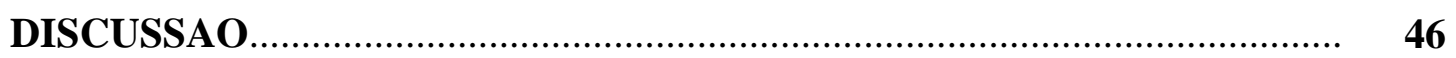

REFERÊNCIAS BIBLIOGRÁFICAS ................................................... 62

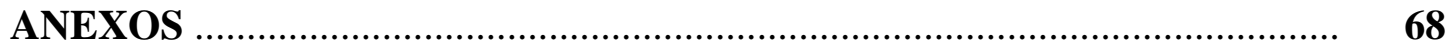

A. Folha de rosto da pesquisa............................................................ 68

B. 1 Questionário parte I.................................................................... 69

B. 2 Questionário parte II (apenas para usuários em versão feminina)...... 72

B. 3 Escalas Psicológicas......................................................................... 75

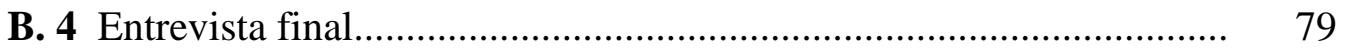




\section{RESUMO}

ALMEIDA, Stella Pereira de. Primeiro perfil do usuário de "êxtase”(MDMA) em São Paulo. São Paulo, 2000, 80p. Dissertação (Mestrado). Instituto de Psicologia, Universidade de São Paulo.

O presente estudo teve como objetivo identificar os padrões de uso de “êxtase”na cidade de São Paulo. Os usuários foram recrutados através da técnica de amostragem snowball, também utilizada para o recrutamento do grupo controle, composto de indivíduos com estilo de vida semelhante aos primeiros mas que nunca haviam experimentado "êxtase”(não usuários). Usuários (52) e não usuários (52) foram entrevistados quanto às características sóciodemográficas e quanto ao uso de drogas psicotrópicas, usuários também responderam questões sobre circunstâncias de uso e efeitos do "ecstasy". Através da Escala de Impulsividade de Barratt e dos Inventários de Depressão de Beck e de Ansiedade TraçoEstado (IDATE-traço) foram medidas impulsividade, depressão e ansiedade de ambos os grupos. Os dois grupos apresentaram características sócio-demográficas semelhantes: a maioria pertencia à classe média, era jovem, heterossexual, solteira e com nível superior. Entre os usuários o consumo de outras drogas psicotrópicas foi expressivamente superior. Outras características mais freqüentes no grupo de usuários foram a presença de tatuagens e piercings, a frequência a "raves" e a preferência pela música eletrônica. No Inventário de Depressão de Beck os usuários apresentaram pontuação significativamente menor quanto à depressão. Os resultados das escalas de impulsividade e ansiedade não apresentaram diferenças significativas entre os dois grupos. Os padrões de uso de “êxtase”dos usuários entrevistados são semelhantes aos padrões descritos por pesquisas realizadas na Europa e em Sidney: a maioria dos usuários consome um ou dois comprimidos a cada episódio de uso, apenas nos finais de semana ou férias, mais freqüentemente na companhia de várias pessoas, em ambientes ligados ao lazer noturno, como lugares para dançar, "raves" e festas. Os comprimidos são geralmente adquiridos de amigos ou conhecidos nesses locais. A maioria dos usuários associa “êxtase”a outras drogas psicotrópicas, particularmente maconha. As características sócio-demográficas dos usuários entrevistados e seus padrões de aquisição e consumo de "êxtase”indicam um caráter pouco marginal do uso. São sugeridas estratégias de Redução de Dano caso o uso de “êxtase”se difunda em São Paulo. 


\section{ABSTRACT}

ALMEIDA, Stella Pereira de. Primeiro perfil do usuário de "ecstasy" (MDMA) em São Paulo. São Paulo, 2000, 80p. Dissertação (Mestrado). Instituto de Psicologia, Universidade de São Paulo.

The present study was aimed at identifying patterns of ecstasy (MDMA) use in the city of São Paulo. Ecstasy users were recruited through the snowball technique. Using the same technique, a control group of subjects that had never tried the drug (non users) was recruited among individuals sharing with users a similar life style. Users $(\mathrm{N}=52)$ and non users $(\mathrm{N}=52)$ were interviewed in order to obtain socio-demographic data and data of user of psychoactive drugs; users were also questionned as to the circumstances surrounding their use of the drug. Besides, levels of anxiety, depression and impulsiveness were assessed through Spielberger's IDATE Trace Inventory, Beck's Depression Inventory and Barratt Impulsiveness Scale. Both users and non users revealed similar socio-demographic characteristics: most subjects were middle class young heterosexual single men and women who had a college degree. Multiple drug using was more frequent among users than among non users. Other features that were significantly more accentuated among users than among non users were the presence of tattoos and piercings, the frequency to raves and the preference for electronic music. Beck Inventory results pointed to significantly lower depression scores among users. No differences were observed between groups in anxiety and impulsiveness scores. Ecstasy consumption patterns among users are similar to those reported in Europe and Australia: most subjects take one or two pillsper episode, during weekends or vacations, usually with company and in social gatherings such as dancings, raves and parties. The drug is predominantly acquired from friends or acquaintances in these same spots. Most users reported consuming ecstasy in combination with other psychoactive drugs, particularly marihuana. The socio-demographic features of users as well as the way they buy and consume the drug suggest that the present pattern of use is not connected to illegal or marginal activities. Harm reduction strategies are suggested in case of ecstasy's use increases and spreads among the young population of the city. 


\section{INTRODUÇÃO}

O uso de drogas psicotrópicas é universal; primitivo e moderno; prejudicial, inócuo ou benéfico; singular, mas comum às mais diferentes culturas humanas em todos os tempos. Em nossa cultura as drogas de abuso, em particular as ilegais, são uma grande preocupação social. Entretanto, as ações que visam conter seu consumo por vezes exageram e por vezes negligenciam seu perigo físico e social.

Neste trabalho é relatada uma pesquisa sobre o uso de "êxtase" (3-4 metilenodioximetanfetamina, ou MDMA), droga psicotrópica ilegal produzida em laboratórios clandestinos, comercializada na forma de comprimidos ou cápsulas que custam atualmente entre R\$ 25,00 e 45,00 em São Paulo. Nos Estados Unidos e Europa seu uso é bastante difundido, sendo conhecida como Ecstasy, Adam (referência a Adão: a inocência no paraíso antes do aparecimento da culpa e da vergonha), XTC ou simplesmente E. Sua via de administração mais comum é a oral, mas ela também pode ser usada por via anal, ou pode ser macerada e aspirada. Vale ressaltar que a facilidade na forma de consumo do "êxtase" pode ser um fator importante para sua popularização. Enquanto as outras drogas ilegais tradicionais (com exceção do LSD) exigem um lugar reservado e por vezes um kit para confecção e consumo, o "êxtase" pode ser consumido com muita discrição em qualquer lugar e não exige nenhuma preparação. Além disso, em quantidade de uso individual, o risco de ser identificado e apreendido pela polícia é mínimo.

\section{Histórico}

Há divergências quanto à data de síntese da MDMA: para alguns ela foi sintetizada em 1912 (Milroy, 1999; Rochester \& Kirchner, 1999), para outros em 1914 (Larangeira, Dunn, Rassi, \& Fernandes, 1996; Schwartz \& Miller, 1997). De qualquer forma, foi patenteada em 1914 pelo laboratório Merck, na Alemanha. A MDMA foi testada inicialmente como moderador de apetite, mas devido a seus efeitos colaterais foi muito pouco utilizada e nunca comercializada, ficando esquecida e sem uso por décadas. Em 1965, o bioquímico americano Alexander 
Shulgin relata ter produzido e consumido MDMA em seu laboratório, sendo o efeito de "uma leveza de espírito bastante prazerosa”. Mas ele só voltou a se interessar pela droga no começo dos anos 70, quando tomou conhecimento de relatos de outros pesquisadores muito entusiasmados com o uso terapêutico da MDMA (Saunders, 1996). A comunidade científica só veio a ser formalmente informada sobre a MDMA com uma publicação de Shulgin e Nichols em 1978, a qual sugere que ela poderia ser utilizada como auxiliar psicoterapêutico (Larangeira et al., 1996). Atualmente, o uso de drogas psicotrópicas alucinógenas como um auxiliar psicoterapêutico é um episódio quase esquecido na história da psiquiatria e da psicologia. Hoje as drogas são utilizadas exclusivamente como tratamento químico: aliviam ou curam sintomas. Entretanto, nas décadas de 50 e 60 foram descritas inúmeras experiências bem sucedidas tendo o alucinógeno LSD (ácido lisérgico) como um catalisador do processo terapêutico (Panke, Kurland, Unger, Savage, \& Grof, 1970), experiências impedidas de prosseguir após essa droga ter sido considerada ilegal. Quando um novo tipo de tratamento medicamentoso é introduzido, é comum um grande entusiasmo e alarde de sucessos, seguidos de desilusão advinda dos insucessos; a experiência de Freud com a cocaína (Cesarotto, 1989) é um exemplo clássico. Entretanto, o ápice e o declínio das psicoterapias com uso de drogas alucinógenas têm algo de incomum na medida em que parecem ter sido banidas antes que insucessos ou prejuízos tivessem sido comprovados pela comunidade científica. O LSD cumpriu esse percurso e a MDMA o sucedeu. No início dos anos 70, a MDMA começou a ser utilizada em contexto terapêutico, como um facilitador do tratamento. Apresentava vantagens sobre seu antecessor, o LSD, pois não provocava mudanças perceptuais e emocionais tão intensas, seus efeitos tinham duração mais curta e não haviam sido relatados flashbacks, "más viagens” ou reações psicóticas, em doses terapêuticas e em contextos controlados. Era utilizada como favorecedora da aliança terapêutica com o profissional na medida em que aumentava a empatia, a confiança no terapeuta e a auto confiança, convidando à auto-análise e favorecendo insights. Os primeiros psicoterapeutas a utilizar a MDMA sabiam do risco que ela corria de seguir os passos do LSD, ou seja, perceberam sua potencialidade de uso com funções recreativas e consequente possibilidade de abuso e ilegalidade. Fizeram então o acordo de desenvolver pesquisas informais sem chamar a atenção do público para a droga. Conseguiram fazê-lo durante um certo tempo, e o período entre 1977 e 1984 é considerado a “época de ouro” da pesquisa terapêutica com a MDMA (Saunders, 1996). 
Em 1984, final da “época de ouro”, a MDMA não só era utilizada como auxiliar terapêutico mas também estava sendo amplamente utilizada pelos jovens norte-americanos como droga recreativa. Pesquisa realizada em 1986 na Universidade de Tulane, EUA, constatou que 15,5\% dos estudantes haviam experimentado “êxtase” pelo menos uma vez na vida (Cuomo, Dyment, \& Gammino, 1994). Em outra pesquisa realizada também em 1986 na Universidade de Stanford, também nos EUA, 39\% dos estudantes declararam ter consumido "êxtase” pelo menos uma vez na vida (Peroutka, 1987). Nessa época a MDMA já era denominada "êxtase", valendo ressaltar o forte apelo mercadológico do nome, e era vendida livremente, a U\$20,00, em bares que aceitavam cartões de crédito (Cloud, 2000; Saunders, 1996). Esse uso público, livre e crescente chamou a atenção da imprensa que em 1985 publicou matérias de capa em várias revistas, como Newsweek, Time e Life. A visibilidade na mídia atraiu mais adeptos e disseminou o uso antes restrito a determinadas cidades norte americanas (Beck \& Morgan, 1986). Além disso, também em 1985, foi divulgado que o uso de uma outra droga sintética chamada White China, sintetizada com o intuito de esquivar-se do controle legal e substituir a heroína, causara graves danos cerebrais em usuários. Comentando o fato, os veículos de comunicação sugeriram que o “êxtase” seria uma droga similar à White China, o que o transformou em neurotóxico potencial e portanto em problema de saúde pública. Por fim, foi publicado um relatório no qual eram apresentadas evidências de danos cerebrais causados pela MDA, droga análoga à MDMA, em ratos (Saunders, 1996). Assim, a popularização do uso de MDMA, a publicidade nos meios de comunicação, o incidente White China e a publicação de artigo sobre o potencial neurotóxico de seu análogo MDA encerraram a fase de uso legal de “êxtase”. Em maio de 1985 a agência Drug Enforcement Administration (DEA) nos EUA convocou uma comissão de emergência para colocar a MDMA na Categoria 1 de substâncias controladas, categoria definida por: (a) alto potencial de abuso, (b) ausência de uso terapêutico/médico e (c) insegurança do uso mesmo com supervisão médica (McClain \& Sapienza, 1989). Em junho de 1986 foram realizadas audiências, e foi mantida sua permanência na ilegalidade e na Categoria 1, ainda que psicólogos e psiquiatras tenham testemunhado a favor do uso da MDMA como auxiliar do processo psicoterapêutico (Grinspoon \& Bakalar, 1986). Até hoje há grupos que defendem a legalização da MDMA. Recentemente foi aprovado o primeiro estudo sobre seu uso terapêutico após ter sido classificada como droga ilegal, em pesquisa que será desenvolvida na Espanha (Cloud, 2000). 
Na Europa o consumo da MDMA sempre foi ilegal, tendo sido introduzido por discípulos de Bhagwan Rajneesh em meados da década de 80 com fins espirituais. Mas é a partir de um evento musical acontecido em Ibiza entre 1987 e 1988, no qual muitos participantes experimentaram MDMA, que surgem as festas conhecidas como raves e com elas o uso de “êxtase” se populariza na Europa. Terminado tal evento os jovens voltaram para seus países com desejo de perpetuar o que tinha se passado. Alguns empreendedores ingleses perceberam que recriar a atmosfera Ibiza seria muito bem aceito. Começaram a organizar festas em armazéns portuários londrinos onde centenas de pessoas pagavam um ingresso e dançavam a noite inteira com música eletrônica ininterrupta, usando “êxtase” ou, na sua falta, LSD. Logo essas festas ganharam cada vez mais adeptos e começaram a acontecer em locais maiores, fora do perímetro urbano mas perto de Londres. Logicamente, festas que reuniam centenas ou milhares de jovens dançando a noite inteira e usando drogas atraíram a atenção da polícia e, em 1990, foi aprovada na Grã-Bretanha uma lei que previa pena de até seis meses de detenção e confisco de todo o lucro dos organizadores de festas-rave. Com isso, os empreendedores desistiram de organizá-las e os ravers se deslocam para os clubes noturnos. Daí para frente o “êxtase” vai fazer parte da cultura dance-clubber (Saunders, 1996). Nos EUA as raves apareceram no início dos anos 90, e assim como na Europa, o uso de "êxtase” faz parte da festa (Schwartz \& Miller, 1997). Ao longo desses dez anos as raves vêm se espalhando pelos EUA. São festas pelas quais é cobrado um ingresso e geralmente são realizadas em algum lugar do deserto, com música eletrônica ininterrupta, centenas ou milhares de participantes e alto consumo de drogas, em especial "êxtase”, LSD e mescalina.

Podemos observar que a ilegalidade da MDMA não parece ter conseguido diminuir o número de usuários recreativos que ao contrário só tem aumentado, como demonstram vários levantamentos realizados tanto na Europa como nos Estados Unidos (Brown, Jarvie, \& Simpson, 1995; Cuomo et al., 1994; Gore, 1999). Além disso, embora a ilegalidade tenha encerrado o uso terapêutico da MDMA, ainda se afirma que seriam necessárias mais pesquisas para descartar seu uso na medicina psiquiátrica (Holland, 1999). 


\section{Uso no Brasil}

Há uma absoluta falta de dados epidemiológicos brasileiros sobre o consumo de “êxtase” e não há publicações sobre seu padrão de uso em nenhuma cidade do Brasil até o presente momento. Nos quatro levantamentos nacionais sobre consumo de drogas, realizados em 1987, 1989, 1995 e 1997, não consta nenhuma questão sobre o "êxtase” como uma das drogas já utilizadas na vida (Carlini, Carlini-Cotrim, Silva-Filho, \& Barbosa, 1990; Carlini-Cotrim, Carlini, Silva-Filho, \& Barbosa, 1989; Galduróz, D'Almeida, Carvalho, \& Carlini, 1994; Galduróz, Noto, \& Carlini, 1997).

Diferentemente da Europa e Estados Unidos onde o uso de “êxtase” é bastante disseminado, no Brasil seu consumo é por enquanto restrito a determinado grupo e desconhecido para a maior parte da população. Entretanto, esse consumo vem provavelmente aumentando, podendo acabar por seguir a tendência americana e européia. Na falta de dados epidemiológicos nos resta a análise pouco sistemática de que no prazo de dois meses foram entrevistados para a presente pesquisa mais de 100 sujeitos que já tinham usado “êxtase” pelo menos uma vez na vida, sendo que 52 deles mais de 10 vezes e alguns mais de 50 vezes.

Segundo o Departamento de Inteligência e Apoio à Polícia (DIAP), divisão do Departamento de Narcóticos de São Paulo (DENARC), foram apreendidos em São Paulo 1140 comprimidos de “êxtase” em 1998, nove comprimidos em 1999 e 613 até junho de 2000. As apreensões de "êxtase" podem não estar diretamente relacionadas ao consumo. É possível que a estratificação social do uso de "êxtase" e seu desconhecimento pela maioria da população determine pouco interesse seja da sociedade seja do governo para uma repressão mais efetiva. Assim, à medida que cresce o interesse e a veiculação de reportagens sobre o assunto é de se supor que também sejam realizadas maiores apreensões.

Na mídia brasileira a visibilidade do "êxtase” vem aumentando. Até 1999 o “êxtase” era citado poucas vezes, grafado em inglês (ecstasy), quase sempre nos cadernos de cultura em matérias ligadas à moda ou comportamento como um signo de grupos ou tendências de vanguarda, sem informações sobre a droga. Vale citar que, em junho de 1999, a revista VejaSão Paulo publicou uma matéria de capa sobre raves na qual curiosamente o “êxtase” não é 
citado. Atualmente observamos cada vez mais citações que começam a ocupar também as páginas policiais, noticiando um crescente número de prisões e apreensões.

As primeiras remessas significativas de "êxtase” chegam a São Paulo em 1994, vindas principalmente de Amsterdã. Nesse momento ainda não havia traficantes de "êxtase", algumas pessoas traziam os comprimidos e os revendiam seletivamente a amigos em clubes noturnos (Palomino, 1999). Se na Europa o consumo de "êxtase” começou nas raves e depois foi para os clubs, em São Paulo seu percurso é inverso. As raves apareceram em 1995, organizadas a princípio por DJs brasileiros vindos de Londres. Nessa época essas festas eram realizadas a cada dois ou três meses com um público menor e menos heterogêneo que hoje. Atualmente em São Paulo há festas-rave todos os finais de semana em lugares amplos e ao ar livre, tais como praias, sítios ou parques aquáticos. Reúnem de três a cinco mil pessoas e duram de catorze a dezoito horas. A música eletrônica é ininterrupta, panos fluorescentes com motivos tântricos ou alienígenas decoram o ambiente e a iluminação é feita com luzes negras, coloridas, estroboscópicas, laser e globos de espelhos. As várias pistas de dança são comandadas por DJs que ocupam o lugar de maior status nas festas, posto que o motivo que une todas essas pessoas é ouvir música e dançar. Os participantes ou ravers se vestem em geral com roupas coloridas, usam adereços fluorescentes, valorizam moda e bodyart, que inclui tatuagens e piercings (aplicação de adereços no corpo). É inegável a presença de "êxtase" nas raves e grande parte de seus usuários estão ali concentrados. Outra parte dos usuários (por vezes sobreposta aos ravers) são portanto os clubbers: indivíduos que frequentam casas noturnas onde também se dança a noite inteira com música eletrônica ininterrupta comandada por $D J s$. A moda é também extremamente valorizada, mas aqui menos colorida e psicodélica, mais geométrica e tecnológica. Tatuagens e piercings também fazem parte da cultura-clubber. Ambos os grupos pertencem na sua maioria à classe alta e média alta e têm bom nível educacional, até porque esse estilo de vida não é barato.

\section{Classificação e composição química}

De acordo com o efeito provocado no sistema nervoso central, as drogas psicotrópicas podem ser classificadas como estimulantes, depressores ou perturbadores de seu funcionamento. As 
drogas perturbadoras são também chamadas de alucinógenas. Com relação a seu efeito a MDMA é uma das poucas drogas com dupla classificação: situa-se entre os estimulantes e os alucinógenos, sendo por vezes classificada como uma anfetamina alucinógena (Larangeira et al., 1996).

A MDMA é frequentemente classificada como droga de desenho, termo com dois significados: (a) qualquer substância fabricada para produzir efeitos específicos, definição pouco elucidativa e muito geral, na qual cabem inúmeras substâncias, ou (b) drogas análogas a substâncias ilegais e com efeitos psicológicos semelhantes, produzidas através de processo de engenharia química, com o objetivo de esquivar-se do controle legal. Por ser análoga à anfetamina e metanfetamina a MDMA é às vezes considerada droga de desenho; entretanto ela foi patenteada em 1914 sem fins determinados e muito antes de tornar-se ilegal nos EUA em 1985. Assim, embora alguns autores definam a MDMA como uma droga de desenho, essa classificação não está bem aplicada (Beck \& Morgan, 1986; Calafat et al., 1998; Cook, 1995).

Dada a dificuldade de enquadrar a MDMA na classificação habitual das drogas psicotrópicas e visando diferenciá-la de outros alucinógenos, foi proposto um termo bastante específico que descreveria os efeitos da MDMA e de seus análogos: Entactogen. O termo é usado para drogas cujos efeitos são aumento de contato consigo mesmo e da introspeção, aumento da empatia e da comunicação com outras pessoas, indução a estado positivo de humor, sentimentos de intimidade e tranquilidade (Schwartz \& Miller, 1997). Esse termo não vingou, mesmo porque estava ligado às experiências terapêuticas com a MDMA encerradas com sua proibição.

A MDMA é produzida sinteticamente em laboratório a partir de metanfetamina. Porém há precursores químicos naturais contidos em óleos de plantas, como noz moscada, endro, cálamo, açafrão, canela e semente de salsa (Elk, 1996). Sua composição química é apresentada na Figura 1. 


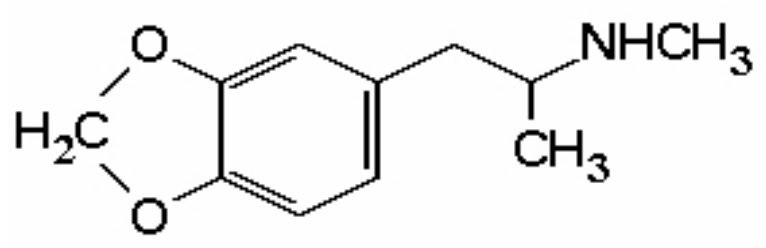

Figura 1. Estrutura química do "êxtase" (3,4 metilenodioximetanfetamina).

Dada sua ilegalidade, sabe-se que nem todos os comprimidos vendidos e consumidos como “êxtase” necessariamente contém MDMA. O êxtase é uma droga sem nenhum controle farmacêutico. Ninguém sabe exatamente o que está consumindo e o "controle” é feito por usuários que já tomaram determinado tipo e aprovaram ou não seus efeitos. Os tipos de "êxtase" ganham apelidos conforme a cor e o desenho impresso nos comprimidos e sua popularidade e preço variam de acordo com os efeitos produzidos. No Brasil, os tipos vão mudando conforme chegam “importações”. Segundo relatos informais de usuários grande parte do "êxtase” consumido no Brasil vem da Europa, e em julho de 1999 em São Paulo os tipos mais comuns eram o JB amarelo, o mitsubishi e o verde RN.

Em 1995 foram realizadas análises nos comprimidos de "êxtase” mais consumidos no Reino Unido. Os resultados mostraram que a maioria contém uma mistura de MDMA com uma ou mais drogas em proporções variadas, e alguns nem sequer contêm MDMA. As outras drogas mais frequentemente associadas à MDMA nos comprimidos de "êxtase" foram: MDEA (análogo sintético da MDMA), metanfetamina, anfetamina, paracetamol, cafeína ou ketamina (Wolff, Hay, Sherlock, \& Conner, 1995). Na Alemanha a análise de comprimidos apreendidos verificou que apenas 47,5\% deles continham MDMA (Sondermann \& Kovar, 1999). Entretanto, há outras pesquisas que averiguaram pouca adulteração nos comprimidos de "êxtase" na Austrália e na Europa, sendo que quando não é puro contém uma mistura de MDMA com seu análogo MDA (Solowij, Hall, \& Lee, 1992). Embora esses dados justifiquem a consonância dos efeitos relatados por usuários de "êxtase” de diversos países, é importante salientar que essas pesquisas foram realizadas ainda na década de 80 e que portanto esse quadro pode ter se alterado, e nesse caso a pesquisa realizada por Wolff e 
colaboradores em 1995 talvez traduza melhor o quadro da composição dos comprimidos hoje em dia. De qualquer forma, o fato é que só uma análise em amostras comercializadas atualmente nos diria se o que é usado como "êxtase” é de fato MDMA. Enquanto isso, o conteúdo dos comprimidos consumidos no Brasil é duvidoso e desconhecido.

\section{Efeitos psicológicos e somáticos}

Os efeitos da MDMA se fazem sentir aproximadamente 20 minutos após a ingestão do comprimido e permanecem por quatro a oito horas (Cook, 1995). Os vários estudos sobre os efeitos provocados pelo “êxtase” apresentam resultados muito semelhantes (Cohen, 1995; Ferigolo, Medeiros, \& Barros, 1998; Solowij et al., 1992; Vollenweider, Gamma, Liechti, \& Huber, 1998). Os efeitos imediatos são descritos na maioria das vezes como prazerosos, embora também sejam apontados efeitos desagradáveis, quase sempre físicos. Já os efeitos 24 horas após a ingestão são descritos como mais negativos, tanto física quanto psicologicamente. A depressão dois dias após o uso de "êxtase" é um efeito descrito por vários pesquisadores (Curran \& Travill, 1997; Parrott \& Lasky, 1998). Os dados descritos pelos pesquisadores citados acima estão reunidos na Tabela 1. 
Tabela 1: Efeitos imediatos e tardios do "êxtase" (MDMA) de acordo com as pesquisas mencionadas no texto.

\begin{tabular}{cll}
\hline EFEITOS & \multicolumn{1}{c}{ IMEDIATOS (4-8 horas) } & \multicolumn{1}{c}{ TARDIOS (24 horas) } \\
\hline P & Loquacidade & \\
S & Abertura mental & \\
I & Proximidade de outras pessoas & Depressão \\
C & Felicidade & Despersonalização \\
O & Bom humor & Flashbacks \\
L & Sensualidade & Preocupação \\
Ó & Euforia & Insônia \\
G & Aumento da autoconfiança & Dificuldade de concentração \\
I & Despreocupação & \\
C & Aumento de energia & \\
O & Excitabilidade sexual & \\
S & Leve sensação de desrealização & \\
& Inapetência & \\
S & Boca seca & Inapetência \\
O & Agitação & Sede \\
M & Aceleração do batimento cardíaco & Falta de energia \\
A & Bruxismo/trismo & Fadiga \\
T & Insônia & Tontura \\
I & Fluxos de frio e calor & Dores musculares \\
C & Sudorese & \\
O & Dificuldade de concentração & \\
S & Vontade de urinar & \\
& Midríase & Náusea \\
& Ataxia (descoordenação motora) & \\
\hline
\end{tabular}

\section{Toxicidade e complicações do uso de MDMA}

Embora a MDMA tenha reputação de droga segura, ou seja, que não apresenta perigo físico (Schwartz \& Miller, 1997), há inúmeros relatos de reações adversas e mortes relacionados à sua ingestão (Lind, Oyefeso, Polland, Baldacchino, \& Ghodse, 1999; McGuire, Cope, \& Fahy, 1994; O' Connor, 1994). Para alguns autores, ainda não há provas de que a MDMA deixe sequelas severas em seres humanos e, embora existam relatos de efeitos adversos agudos, o números de casos é surpreendentemente pequeno em relação ao número de usuários (Bailly, 1999; Creighton, Black, \& Hyde, 1991; Grob, Poland, Chang, \& Ernst, 1996). Parece que reações severas ou fatais ao "êxtase" são idiossincráticas e multifatoriais. Assim como já se observou casos de morte após a ingestão de apenas um comprimido, há um caso no qual 
tendo ingerido 40 comprimidos o indivíduo não apresentava alterações de pressão ou temperatura, embora com concentrações séricas de MDMA muito altas (Finechi, Centini, Mazzeo, \& Turillazzi, 1999; Regenthal, Kruger, Rudolph, Trauer, \& Preiss, 1999).

Há dois problemas relativos à segurança e ao perigo da MDMA: um deles é a incerteza da composição dos comprimidos, e o outro seria a mistura que frequentemente usuários fazem com outras drogas, como estimulantes, opiáceos e álcool. Não há dúvida de que essas duas questões estão diretamente relacionadas ao aumento do potencial de perigo, toxicidade e risco de efeitos adversos agudos relacionados à MDMA. Também é importante salientar que a toxicidade de qualquer droga é dependente da dose, da frequência de uso, da vulnerabilidade individual e das condições externas ambientais (Huether, Zhou, \& Ruther, 1997). Nos últimos anos, os padrões de uso de "êxtase" mudaram muito. Da utilização em isolamento ou em pequenos grupos de amigos passou a ser usado em clubs ou raves. Como já foi observado, esses locais são espaços para se dançar horas seguidas, ao som de música eletrônica muito alta e ininterrupta, lugares com centenas de pessoas, com temperatura elevada, nem sempre com a ventilação adequada. Pode-se bem supor que essa mudança no ambiente de uso de "êxtase" esteja associada ao aumento no número de casos de mortes e intoxicações. De fato, foi demonstrado em ratos o fenômeno da toxicidade anfetamínica de agrupamento, que significa que tanto os efeitos comportamentais quanto os efeitos tóxicos da anfetamina aumentam quando os animais são agrupados em relação a quando estão isolados. Mesmo quando a área total por animal é a mesma, observou-se um aumento da toxicidade anfetamínica em condições de agrupamento e temperaturas mais altas. Além disso também se observou que para animais colocados em caixas individuais a toxicidade é diretamente proporcional à temperatura ambiente, ruído externo e pouca hidratação. Essas constatações podem ser relevantes para o estudo da toxicidade da MDMA, já que seu uso em raves e clubs apresenta as características de propensão a maior toxicidade, ao menos por analogia à anfetamina (Green, Cross, \& Goodwin, 1995).

Dentre as complicações clínicas, a hipertermia é a ocorrência mais frequente associada à MDMA, quadro no qual os usuários podem chegar a temperaturas corporais de $42^{\circ} \mathrm{C}$. A razão pela qual a MDMA afeta a termoregulação corporal não é clara, mas parece estar relacionada com o aumento de liberação de serotonina. As condições externas habitualmente associadas 
ao uso de "êxtase”, ou seja, exercício físico intenso em ambiente quente e falta de hidratação, aumentam consideravelmente o risco de hipertermia. Ela pode causar desidratação, rabdomiólise, o que desencadeia coagulação intravascular disseminada (DIC), provocando convulsões e morte. Até 1994 haviam sido relatados vinte e seis casos de hipertermia na Inglaterra, dos quais nove letais (O' Connor, 1994). Para combater o risco amplamente divulgado de desidratação os usuários costumam beber grandes quantidades de água (está descrito um caso de morte após ingestão de 13 litros), cujos efeitos podem ser hipotermia (Box, Prescott, \& Freestone, 1997) e edema cerebral (Matthai, Davidson, Sills, \& Alexandrou, 1996). Também estão documentados vários casos de problemas hepáticos relacionados ao uso de MDMA, desde icterícia até falência renal aguda com necessidade de transplante ( $\mathrm{O}^{\prime}$ Connor, 1994). O mecanismo pelo qual a MDMA ocasiona problemas hepáticos ainda não está claramente definido, mas parece ser uma reação idiossincrática, pois independe da dose e da frequência de uso e pode ocorrer tanto após o primeiro quanto após vários episódios de uso de MDMA (Finechi et al., 1999; Schwab, Seyringer, Brauer, Hellinger, \& Griese, 1999). Foi registrado um caso de retenção urinária após o uso de grande quantidade de MDMA (15 comprimidos em 36 horas), efeito provavelmente devido à ação agonista alfa adrenérgica da MDMA (Bryden, Rothwell, \& PH, 1995).

Em relação a problemas psiquiátricos ainda é pouco conhecida a morbidade psiquiátrica associada ao uso de “êxtase”. Entretanto há casos de psicoses documentados: psicose crônica atípica, psicose atípica e mais frequentemente psicoses paranóicas. Na grande maioria dos casos o estado clínico do paciente responde bem aos neurolépticos, psicofármaco classicamente utilizado em distúrbios psicóticos (Bailly, 1999; Creighton et al., 1991; McGuire et al., 1994). Foram também descritos nove casos de ataque de pânico consequentes ao uso de "êxtase”. Esses quadros tiveram uma duração limitada aos efeitos do "êxtase", alguns tiveram recidivas em novos episódios de uso outros não. Há relato de um caso que evoluiu para um distúrbio de pânico. Quando medicados, respondem bem aos tratamentos farmacológicos clássicos (Bailly, 1999; Whitaker-Azmitia \& Aronson, 1989). Há casos em que o uso de “êxtase” está associado à ideação suicida e ao suicídio. Embora esteja comprovado que há uma correlação entre baixos níveis de ácido 5-hidroxi-indolacético (5HIAA) cérebro-espinhal e suicídio, e que a MDMA causa esgotamento cerebral de serotonina (5-HT) e de 5-HIAA, não se pode concluir que a MDMA seja a única responsável por essa 
associação (Cohen, 1996). Embora a MDMA seja geralmente descrita como uma droga não adictiva, ou seja, que não causa dependência, foram descritos casos clínicos que preenchem os critérios de síndrome de dependência ao "êxtase" (Jansen, 1999). Experimento realizado com babuínos mostrou que a MDMA age como reforçador, resultado que sugere potencial de abuso (Lamb \& Griffiths, 1987).

O desenvolvimento da tolerância decorrente do uso frequente de MDMA não se dá de forma homogênea para todos os sintomas. Com o uso habitual, a intensidade dos efeitos colaterais indesejáveis tais como inapetência, trismo, náusea, dores musculares, ataxia, sudorese, taquicardia, fadiga e insônia aumentam, enquanto diminuem os efeitos subjetivos prazerosos, como melhora do humor e alucinações (Solowij et al., 1992). Por isso, é comum os usuários fazerem pausas abstinentes retomando o uso após algumas semanas, a fim de recuperar os efeitos positivos anteriores ao estabelecimento de tolerância.

Em relação às funções cognitivas, estudos realizados com usuários crônicos de "êxtase" encontrou prejuízos de memória e atenção quando comparados a controles não usuários (Krystal, Price, Opsahl, Ricaurte, \& Heninger, 1992). Outro pesquisador também detectou prejuízos de atenção e memória diretamente relacionados à dose, à frequência e ao tempo de uso de "êxtase" (McCann, Mertl, Eligulashvili, \& Ricaurte, 1999). Em ratos, embora a MDMA tenha causado redução dos níveis de 5-HT cerebral, a memória não foi afetada (Ricaurte et al., 1993). Mas, segundo o NIDA (National Institute on Drug Abuse), um estudo comparativo entre não usuários e usuários habituais indicou que esses apresentavam prejuízos significativos de memória verbal e visual. Os prejuízos são diretamente proporcionais à dose e permanecem no mínimo duas semanas após o uso ser interrompido. Isso parece estar relacionado a danos causados aos neurônios serotonérgicos (NIDA, 1998). Ainda com relação à memória, foi descrito um caso de síndrome amnésica em decorrência da ingestão de "êxtase". Após nove meses a paciente ainda apresentava pequeno prejuízo de memória (Spatt, Glawar, \& Mamoli, 1997).

Também foi observado que o uso de "êxtase" afeta o sono dos usuários. Foram comparados os tempos totais de sono de usuários (com mais de 25 episódios de uso) e de indivíduos que nunca haviam utilizado “êxtase”. Os sujeitos de ambos os grupos não usavam drogas 
psicotrópicas há duas semanas. Constatou-se que os usuários têm menos tempo total de sono do que não usuários, e que essa diferença se deve a um menor tempo de sono não-REM entre os usuários (Allen, McCann, \& Ricaurte, 1993). Também são relatados outros efeitos sobre o sono de usuários de “êxtase”: insônia, inversão do ritmo vigília/sono, pesadelos, alucinações hipnagógicas e bruxismo (Bailly, 1999).

Foi demonstrado que usuários de "êxtase" apresentam desgaste dos dentes significativamente maior do que não usuários. Esse desgaste é atribuído ao bruxismo provocado pela droga. O desgaste dentário é ainda exacerbado quando o "êxtase” é associado à ingestão de bebidas gasosas, o que ocorre frequentemente (Redfearn, Agrawal, \& Mair, 1998). São ainda relatados problemas dermatológicos e emagrecimento em usuários habituais de "êxtase".

O uso de "êxtase" por gestantes está associado a um aumento de má formações congênitas, predominantemente anomalias cardiovasculares e músculo-esqueléticas (McElhatton, Bateman, Evans, Pughe, \& Thomas, 1999).

Por último parece que a MDMA deprime o sistema imunológico, em especial quando associada ao álcool. Entretanto essa observação foi feita em pesquisa realizada com um pequeno número de sujeitos, o que significa que amostras maiores seriam necessárias para comprovar essa ação (Pacifici et al., 1999).

\section{Mecanismo de ação no sistema nervoso central}

A administração de MDMA em animais desencadeia uma resposta bifásica que pode ser dividida em efeitos de curto prazo (primeiras 24 horas) e de longo prazo (que permanecem após 24 horas, podendo durar até mais de 12 meses). Os efeitos psicológicos e comportamentais de curto prazo parecem estar mais diretamente ligados à estimulação serotonérgica, enquanto os efeitos de longo prazo estão mais relacionados ao desenvolvimento de neurotoxicidade serotonérgica (McKenna \& Peroutka, 1990). 
(a) Efeitos de curto prazo

Ação sobre a 5-HT e 5-HIAA

A MDMA promove a liberação de 5-HT, sendo um agonista serotonérgico indireto. A MDMA atravessa rapidamente a membrana pré-sináptica; ainda não se sabe se isso se dá passivamente ou através de um transportador. Após atravessar a membrana do neurônio a MDMA causa efluxo de 5-HT da vesícula onde fica armazenada para o citoplasma. A liberação de 5-HT ocasionada pela MDMA parece ser cálcio-independente o que é uma evidência de que é proveniente do citoplasma e não diretamente das vesículas sinápticas, posto que a liberação de 5-HT vesicular é cálcio-dependente (Rattray, 1991). Corrobora essa hipótese a afirmação de que a liberação de 5-HT promovida pela MDMA é sódio-dependente (Huether et al., 1997). Do citoplasma da célula nervosa a 5-HT é rapidamente liberada para o espaço extracelular através de transportadores serotonérgicos. A liberação de 5-HT induzida pela MDMA pode ser bloqueada por inibidores de recaptação de serotonina, como por exemplo a fluoxetina (Huether et al., 1997; Rattray, 1991). Essa observação sugere duas hipóteses: a primeira é de que a MDMA é transportada passivamente para dentro da célula nervosa desencadeando a liberação de 5-HT vesicular para o citoplasma; nesse caso, a fluoxetina bloquearia os transportadores impedindo a liberação de 5-HT citoplasmática na fenda. Uma segunda hipótese seria de que a passagem da MDMA através da membrana necessita de um transportador e nesse caso a fluoxetina, bloqueando o transportador, impediria que a MDMA atravessasse a membrana e promovesse a liberação de 5-HT da vesícula para o citoplasma (Rattray, 1991).

Além de promover a liberação de 5-HT, estudos in vitro mostraram que a MDMA tem capacidade de inibir sua recaptação pelos terminais nervosos. In vivo, parece que a MDMA também tem ação inibitória sobre os transportadores responsáveis pela recaptação de 5-HT. O bloqueio de recaptação de 5-HT prolongaria as ações pré e pós-sinápticas da liberação de 5HT, aumentando efetivamente sua concentração na fenda sináptica (Rattray, 1991). A MDMA também provoca decréscimo na atividade da enzima triptofano-hidroxilase (TPH), enzima responsável pela síntese de 5-HT (McKenna \& Peroutka, 1990). O mecanismo preciso através do qual a MDMA interfere na atividade da TPH é desconhecido. Uma hipótese é de que, direta ou indiretamente, a MDMA tenha um efeito oxidativo nos terminais nervosos, o que pode inativar a TPH (Rattray, 1991). A liberação maciça de 5-HT, somada ao bloqueio de sua 
recaptação e à inativação da TPH, resulta no esgotamento intraneuronal de 5-HT e do 5HIAA. Após uma única dose de MDMA o esgotamento de 5-HT é rápido, ocorrendo entre uma e três horas após sua administração. Em ratos, reduções na concentração de 5-HT e 5HIAA chegam a 80\% em três horas (McKenna \& Peroutka, 1990).

Cabe notar ainda que a MDMA tem grande afinidade pelo sub-receptor serotonérgico 5- $\mathrm{HT}_{2}$, o qual é considerado responsável pelos os efeitos alucinógenos causados pelo LSD. Isso sugere que a ligação da MDMA a esse receptor module os efeitos alucinógenos atribuídos a ela.

\section{Ação da MDMA sobre a dopamina (DA) e noradrenalina (NA)}

Embora a anfetamina e a metanfetamina sejam potentes agentes liberadores de DA, a MDMA é muito seletiva no esgotamento de 5-HT, in vivo e in vitro (Gazzara, 1989; Rattray, 1991) Em contraste com a acentuada redução intracelular de 5-HT e de 5-HIAA consequentes à administração de MDMA, não foram observadas mudanças similares nos níveis de DA ou NA (McKenna \& Peroutka, 1990). In vitro, demonstrou-se que a MDMA bloqueia a recaptação de DA e NA, embora tenha baixa afinidade pelo transportador dopaminérgico. In vivo, há poucas evidências sugerindo que a MDMA cause, diretamente, liberação de DA na maioria das regiões cerebrais (Rattray, 1991). Pesquisa mais recente descreve que a MDMA estimula a liberação de DA em sinapses dopaminérgicas (Huether et al., 1997). Segundo seus autores, parece que a MDMA ultrapassa a membrana pré-sináptica através de um processo passivo, causando a liberação de DA vesicular através de um mecanismo similar ao que ocorre nos neurônios serotonérgicos. O transporte da DA citoplasmática livre para a fenda sináptica é mediado por transportadores dopaminérgicos da membrana. Ainda segundo esses autores a ativação dos receptores $5 \mathrm{HT}_{2 \mathrm{~A}}$, através da liberação de 5-HT, parece facilitar a liberação de DA induzida pela anfetamina, enquanto a administração de antagonistas de 5- $\mathrm{HT}_{2 \mathrm{~A}}$ atenua os efeitos de análogos anfetamínicos (como por exemplo a MDMA) na liberação de DA. É bem possível que a MDMA ocasione a liberação de NA em terminais noradrenégicos através de um mecanismo similar ao da liberação de DA, mas esse efeito ainda não foi investigado.

A interação com o receptor alfa-2 adrenérgico deve ser relevante para os efeitos cardiovasculares, ou seja, aumento do batimento cardíaco, hipertensão e arritmias. Além da 
afinidade da MDMA pelo transportador de 5-HT e pelo receptor alfa-2 adrenérgico , a MDMA também tem afinidade pelo receptor de acetilcolina, receptor muscarínico M1, e receptor histamínico H1 (Rattray, 1991). Não se sabe, porém, o papel funcional dessas ligações.

(b) Efeitos de longo prazo

Níveis cerebrais de 5-HT e 5-HIAA

Vários pesquisadores descreveram que a MDMA é responsável por reduções duradouras nos níveis cerebrais de 5-HT e 5-HIAA, em alguns casos persistindo por mais de 12 meses (Green et al., 1995; McKenna \& Peroutka, 1990; Rattray, 1991). Também a diminuição da atividade da TPH em consequência da administração de MDMA é duradoura, sua atividade cortical permanece significativamente reduzida uma semana após sua administração. Isso indica a irreversibilidade da inativação da TPH pela MDMA, de forma que seu restabelecimento depende da síntese de nova enzima (Green et al., 1995). Estudos in vitro e in vivo constataram que a administração crônica de MDMA causa diminuição na densidade de receptores 5-HT, em ratos. Em seres humanos também foi observada diminuição na densidade de receptores 5HT em usuários crônicos de MDMA (McCann, Szabo, Scheffel, Dannals, \& Ricaurte, 1998). Entretanto há várias críticas a essa pesquisa humana no que diz respeito ao método, tanto em relação à amostra quanto à técnica empregada (Jansen \& Forrest, 1999; Morgan, 1999; Reed, Winstock, Cleare, \& McGuire, 1999). Tais críticas sugerem que ainda não há dados conclusivos no que se refere a essa questão.

Assim, embora haja indicações de que a MDMA seja potencialmente neurotóxica ainda são desconhecidos os mecanismos através dos quais se dá sua toxicidade. 


\section{Objetivos desta pesquisa}

Esta pesquisa visa delinear um primeiro perfil do usuário de “êxtase” na cidade de São Paulo. Se o consumo de "êxtase” no Brasil seguir a tendência americana e européia, teremos em muito pouco tempo um uso disseminado, popular e em moda, sem que os profissionais da saúde estejam preparados para sua compreensão.

Os objetivos desta pesquisa são portanto:

1. Descrever a população de usuários habituais de "êxtase" que compõe a amostra ,

2. Descrever os padrões de uso de "êxtase" da população entrevistada,

3. Listar os efeitos atribuídos ao "êxtase" relatados pelos sujeitos, e compará-los com dados de pesquisas internacionais,

4. Comparar, por meio da aplicação de escalas padronizadas, usuários habituais de "êxtase" e não usuários quanto as seguintes características: impulsividade, ansiedade e depressão. 


\section{MÉTODO}

\section{Sujeitos}

Foram entrevistados 184 indivíduos dos quais 76 nunca tinham experimentado “êxtase” e 108 já o tinham utilizado pelo menos uma vez na vida.

Classificação da população pesquisada quanto ao padrão de uso de "êxtase". Na literatura não há uniformidade na classificação de usuários de "êxtase”: pesquisadores diferentes usam categorias diferentes. Parrott divide os sujeitos em dois grupos de acordo com o número de episódios de uso: usuários regulares, que usaram dez ou mais vezes, e novatos, que usaram até nove vezes (Parrott \& Lasky, 1998). Já Calafat categoriza usuários europeus em cinco grupos conforme a frequência atual de uso: usuários ocasionais são os que usam “êxtase” uma ou menos de uma vez por mês; usuários habituais são os que usam mais de uma vez por mês e no máximo uma vez por semana; compulsivos são os que usam mais de uma vez por semana, e ex-usuários são definidos como um grupo heterogêneo que inclui indivíduos que usaram a droga uma ou duas vezes e não continuaram a usá-la (Calafat et al., 1998). Por sua vez, Solowij classifica os usuários australianos pesquisados em dois grupos: usuários experimentais são aqueles que utilizaram "êxtase" de uma a três vezes, e os que usaram mais de três vezes são subdivididos conforme sua frequência atual em nove padrões diferentes (Solowij et al., 1992).

As classificações acima descritas são muito amplas ou muito específicas. Uma vez que não há um padrão estabelecido para a classificação de usuários de “êxtase” e que o uso no Brasil não é tão comum quanto nos países em que foram realizadas tais pesquisas, pareceu mais adequado agrupar a população entrevistada segundo outro parâmetro. Assim, tendo como referência os autores citados e como intuito a adequação aos padrões de uso dos sujeitos entrevistados, as seguintes categorias foram definidas: 
0. Não usuários: Indivíduos que nunca experimentaram “êxtase”.

1. Usuários habituais: Indivíduos que usaram êxtase mais de 10 vezes na vida e pelo menos uma vez no último mês.

2. Usuários experimentais: Indivíduos que usaram êxtase de uma a três vezes na vida.

3. Usuários esporádicos: indivíduos que usaram êxtase mais de 10 vezes na vida mas não usavam há pelo menos dois meses, referindo frequência inferior à bimestral.

4. Ex-usuários: indivíduos que usaram êxtase mais de 10 vezes na vida mas não o utilizam há um ano ou mais.

5. Outros usuários: Indivíduos que usaram êxtase entre cinco e oito vezes na vida.

A Tabela 1 indica o número de entrevistados conforme sua categoria de uso.

Tabela 1. Número de entrevistados conforme sua categoria de uso.

\begin{tabular}{lc}
\hline \multicolumn{1}{c}{ CATEGORIA } & N \\
\hline $\mathbf{0}$ - Não Usuário & 76 \\
$\mathbf{1}$ - Usuário Habitual & 52 \\
$\mathbf{2}$ - Usuário Experimental & 33 \\
$\mathbf{3}$ - Usuário Esporádico & 7 \\
$\mathbf{4}$ - Ex-usuário & 6 \\
$\mathbf{5}$ - Outros usuários & 10 \\
\hline TOTAL & $\mathbf{1 8 4}$ \\
\hline
\end{tabular}

Critérios de exclusão/inclusão. Com o objetivo de tornar a amostra de não usuários o mais semelhante possível da amostra de usuários foram excluídos da análise os questionários de não usuários que responderam que nenhum amigo usava "êxtase” (questão $21=1$ ). Também foi adotado como critério de exclusão questionários com mais de uma escala inválida. Por essas razões foram excluídos da análise 24 questionários de não usuários. Como a amostra de usuários foi bastante heterogênea em relação à frequência de uso, foi adotado como critério de inclusão na análise ser categorizado como usuário habitual. Portanto, nos resultados são 
analisados dois grupos de sujeitos: usuários habituais, daqui em diante denominados apenas usuários, e não usuários, que constituíram o grupo controle.

\section{Instrumentos.}

Foram utilizados três instrumentos. O primeiro foi um questionário de auto preenchimento elaborado pela pesquisadora com base em dois outros questionários aplicados em pesquisas sobre o uso de “êxtase” na Europa e na Austrália (Calafat et al., 1998; Solowij et al., 1992). O questionário foi elaborado em três versões diferentes, para: (a) usuários do sexo masculino, (b) usuárias do sexo feminino, e (c) não usuários de ambos os sexos. Cada questionário era composto de duas partes: (1) questões sobre dados sócio-demográficos, uso de drogas na vida e no mês antecedente à entrevista (questionários a, b e c), e (2) questões sobre frequência, padrões de uso e efeitos do "êxtase” (questionários a e b, somente para usuários). O segundo instrumento utilizado foram três escalas de auto preenchimento: (A) Inventário de Ansiedade Traço-Estado (IDATE-Traço) (Spielberger, Gorsuch, \& Lushene, 1979), (B) Inventário de Depressão de Beck traduzido e validado por Gorenstein (Gorenstein \& Andrade, 1998), e (C) Barrat Impulsivity Scale (Patton, Stanford, \& Barrat, 1995) traduzido por Hermano Tavares. O terceiro instrumento utilizado foi uma entrevista dirigida final, cujas respostas foram anotadas pela entrevistadora. Todos os instrumentos são apresentados no Anexo B.

Escolha das características e escalas a serem pesquisadas. Segundo Nardi (1998), a ansiedade “(...) é um sentimento útil. Sem ela estaríamos vulneráveis aos perigos e ao desconhecido. É algo que está presente no desenvolvimento normal, nas mudanças e nas experiências inéditas” (Nardi, 1998). Assim, o nível de ansiedade poderia diferenciar usuários de não usuários na medida em que indivíduos mais ansiosos teriam mais resistência a experimentar uma droga nova e desconhecida. A característica depressão foi escolhida porque a MDMA provoca um esgotamento nos níveis de 5-HT e 5-HIAA a curto prazo, para alguns autores também a longo prazo, e sabe-se que a diminuição nos níveis de 5-HT está diretamente relacionada à patogênese da depressão (Graeff, 1989). Já a característica impulsividade foi escolhida porque há um estudo no qual é relatada sua relação direta com o uso de êxtase (Morgan, 1998). Escolhidas as características a serem pesquisadas, as escalas 
selecionadas precisavam ser de auto preenchimento, ter um tempo de aplicação de aproximadamente 10 minutos, ter versão em português, e estarem entre as mais utilizadas.

\section{Procedimento}

Recrutamento de sujeitos. Foi adotada a técnica snowball, em português bola de neve, por ser particularmente adequada ao estudo de fenômenos sociais em áreas da ilegalidade, sendo igualmente importante sua utilidade na exploração de populações pouco conhecidas (Kaplan,1987). Posto que o uso de “êxtase” é uma atividade social, ilegal e que até o momento é muito pouco conhecida no Brasil, a técnica de recrutamento de sujeitos snowball pareceu ser a mais adequada à presente pesquisa. Os sujeitos foram então recrutados através dessa técnica de amostragem, a qual foi primeiramente descrita e formalizada por Goodman em 1961. Consiste em uma corrente ascendente de sub-amostras, compostas a partir de um grupo inicial de $k$ indivíduos selecionados em virtude de sua disponibilidade e características específicas conforme o que se intente estudar. Esses sujeitos iniciais compõem a primeira subamostra ou Estágio 0 e são convidados a indicar outros $k$ indivíduos, que formarão o Estágio 1 e que também são convidados a indicar outros $k$ indivíduos que por sua vez formarão o Estágio 2, e assim por diante até que se atinja o número de sujeitos necessários à amostra (Goodman, 1961).

Aplicação dos questionários. A aplicação foi feita sempre pela mesma entrevistadora. Primeiramente foi feito contato com os sujeitos iniciais (Estágio 0). Foram selecionados seis indivíduos conhecidos da entrevistadora com as seguintes características: "pessoas que participem de uma atmosfera onde o uso de "êxtase" não seja estranho ou incomum”. Esses sujeitos foram contatados pessoalmente ou por telefone, e convidados a participar de pesquisa sobre uso de drogas. A cada sujeito era solicitada indicação de outras pessoas com as mesmas características que os tornaram sujeitos, ou seja, era solicitada a indicação de "pessoas que façam parte de seu círculo de amizades, tenham ou não feito uso de "êxtase", mas que frequentem casas noturnas, raves, ou festas onde o uso de êxtase não seja desconhecido ou incomum”. O contato inicial com os sujeitos dos estágios seguintes foi feito de duas formas diferentes: por telefone ou através de indicações de conhecidos em locais públicos. Aos 
sujeitos contatados por telefone a entrevistadora se apresentava como psicóloga fazendo uma pesquisa sobre uso de drogas e dizia quem havia dado seu contato. Havendo concordância em responder ao questionário, a entrevistadora informava o tempo aproximado da entrevista e solicitava que o sujeito escolhesse horário e local que mais lhe conviesse, sendo requerido que fosse um lugar calmo, com o mínimo de interferência possível e que o sujeito não tivesse consumido nenhum tipo de psicotrópico (exceto tabaco) por pelo menos 12 horas. Eram também oferecidos dois locais para entrevista: no campus da USP ou em um escritório comercial no bairro do Itaim Bibi. Os sujeitos contatados em locais públicos foram indicados por sujeitos já entrevistados que se ofereceram para acompanhar a pesquisadora a locais onde conheciam usuários e/ou pessoas que tivessem perfil para responder ao questionário. Nesses locais apresentavam seus amigos ou conhecidos à pesquisadora, e a esses era informado que se tratava de uma pesquisa sobre drogas e era solicitada a leitura da folha de rosto da pesquisa (Anexo A). Caso concordasse em participar, perguntava-se ao sujeito se ele havia consumido algum tipo de droga psicotrópica (exceto tabaco) nas últimas 12 horas e em caso afirmativo explicava-se que ele não poderia responder ao questionário naquele momento. Caso o sujeito dissesse não haver consumido nenhuma droga nas últimas 12 horas, perguntava-se se já havia usado "êxtase" alguma vez na vida para que fosse entregue o questionário correspondente. Os locais visitados foram: uma galeria comercial $(\mathrm{G})$, três casas noturnas ou bares (CB1, CB2, CB3), um bar de universidade (B) e uma universidade (U). O número de sujeitos entrevistados em cada local encontra-se na Tabela 2.

Tabela 2. Distribuição da amostra conforme o local de realização da entrevista

\begin{tabular}{lc}
\hline \multicolumn{1}{c}{ LOCAL } & N \\
\hline Local escolhido pelo sujeito & 23 \\
G & 114 \\
B & 15 \\
CB1/CB2/CB3 & 15 \\
U & 17 \\
\hline \multicolumn{1}{r}{ TOTAL } & $\mathbf{1 8 4}$
\end{tabular}


Análise. Os dados foram armazenados em banco de dados do Programa SPSS 7.5, também utilizado para a análise estatística. Para a comparação das respostas de usuários e não usuários quanto à variável idade foi usado o teste $t$, para renda e gasto semanal para sair foi utilizado o teste $U$ de Mann-Whitney, e para a análise das outras questões sobre dados sóciodemográficos e sobre uso de drogas foi realizado o teste do qui-quadrado (Pearson). As questões 22 a 38, que são questões sobre os padrões de uso e comportamento em relação ao “êxtase” respondidas apenas pelo grupo de usuários, são apresentadas em termos de frequência. Para cada uma das escalas psicológicas foi calculado o coeficiente $\alpha$ de Cronbach e foi realizado o teste $t$ ou teste do qui-quadrado para comparar as diferenças entre os dois grupos. 


\section{RESULTADOS}

\section{Distribuição da amostra conforme os estágios de recrutamento}

Com relação ao recrutamento dos sujeitos, o estágio zero foi composto por seis indivíduos e a partir dele diferentes estágios foram atingidos. Assim, um dos sujeitos do estágio zero, sujeito número cinco, não desencadeou mais entrevistas enquanto outro, o sujeito número três, desencadeou entrevistas que chegaram ao $5^{\circ}$ estágio, conforme mostra a Tabela 3.

Tabela 3. Distribuição da amostra conforme estágios de recrutamento

\begin{tabular}{|c|c|c|c|c|c|c|}
\hline $\begin{array}{c}\text { ESTÁGIO } \\
0\end{array}$ & $\begin{array}{c}\text { ESTÁGIO } 1 \\
\mathrm{~N}\end{array}$ & $\begin{array}{c}\text { ESTÁGIO } 2 \\
\mathrm{~N}\end{array}$ & $\begin{array}{c}\text { ESTÁGIO } 3 \\
\mathrm{~N}\end{array}$ & $\begin{array}{c}\text { ESTÁGIO } 4 \\
\mathrm{~N}\end{array}$ & $\begin{array}{c}\text { ESTÁGIO } 5 \\
\mathrm{~N}\end{array}$ & TOTAL \\
\hline Sujeito 1 & 3 & 5 & 8 & 11 & - & 28 \\
\hline Sujeito 2 & 6 & - & - & - & - & 7 \\
\hline Sujeito 3 & 2 & 6 & 20 & 13 & 93 & 135 \\
\hline Sujeito 4 & 6 & - & - & - & - & 7 \\
\hline Sujeito 5 & - & - & - & - & - & 1 \\
\hline Sujeito 6 & 5 & - & - & - & - & 6 \\
\hline TOTAL & 22 & 11 & 28 & 24 & 93 & 184 \\
\hline
\end{tabular}

\section{Recusas}

O número de pessoas que se recusaram a responder o questionário foi surpreendentemente pequeno; ao todo foram cinco recusas. Um indivíduo convidado por sujeito do Estágio 0 disse não querer dar entrevista sobre o assunto porque não se sentia um bom representante do grupo que usava “êxtase”, mas indicou outra pessoa para ser entrevistada. Dois indivíduos contatados em local público se recusaram a responder, um deles após ler a folha de rosto do 
questionário e outro antes mesmo de fazê-lo. Nenhum dos dois quis explicitar o motivo da recusa. Outros dois indivíduos alegaram não ter tempo para responder, sendo que um deles solicitou o questionário e disse que o devolveria pelo correio, mas a pesquisadora não aceitou.

Com relação ao veto da pesquisadora, três indivíduos foram impedidos de responder, dois porque tinham consumido álcool, e um por ter fumado maconha. Todos os outros sujeitos negaram ter feito uso de psicotrópicos (exceto tabaco) pelo menos 12 horas antes da entrevista.

\section{Dados sócio-demográficos da amostra de usuários e não usuários}

A Tabela 4 mostra a idade e a Tabela 5 mostra outros dados sócio-demográficos dos 104 questionários analisados, compreendendo 52 questionários de cada grupo. Nota-se que usuários e não usuários apresentam grande semelhança em relação a essas características, apresentando predominantemente maior concentração de indivíduos jovens, heterossexuais, solteiros, de nível superior e de classe média. Para a variável idade, as médias e os desvios padrão são muito próximos para ambos os grupos, não havendo diferenças significativas entre eles. Entretanto quando se categoriza as idades conforme faixas etárias estabelecidas pela Organização Mundial de Saúde (OMS) (Baleeiro, Siqueira, Cavalcanti, \& Sousa, 1999) observa-se que as diferenças são significativas. Há diferenças entre os dois grupos quanto à opção sexual, pois a proporção de bissexuais é maior na amostra de usuários (19,6\%) do que na de não usuários $(8,0 \%)$, enquanto que a proporção de heterossexuais é maior entre não usuários $(78,0 \%)$ do que entre usuários (66.7\%). Entretanto essa diferença não foi estatisticamente significativa. A variável que mais diferencia os dois grupos é a ocupação, onde a amostra de não usuários tende a apresentar maior concentração de estudantes (63,5\%), enquanto o grupo de usuários parece estar mais segmentado entre "trabalho fixo", "free lancer/bicos" e "estudo". 
Tabela 4. Idade dos usuários e não usuários

\begin{tabular}{ccccc}
\hline & USUÁRIOS & NÃO USUÁRIOS & $t=$ & $\boldsymbol{p}$ \\
\hline IDADE (anos) & 15 & 15 & 1,463 & NS \\
Mínima & 37 & 40 & & \\
Máxima & $24 \pm 5$ & $22,4 \pm 6$ & & \\
Media + desvio padrão & & & \\
\hline
\end{tabular}

Tabela 5. Características sócio-demográficas dos usuários e dos não usuários

\begin{tabular}{|c|c|c|c|c|c|c|}
\hline & \multicolumn{2}{|c|}{ USUÁRIOS } & \multicolumn{2}{|c|}{ NÃO USUÁRIOS } & \multirow[b]{2}{*}{$\chi^{2}=$} & \multirow[b]{2}{*}{$p$} \\
\hline & $\mathrm{N}$ & $\%$ & $\mathrm{~N}$ & $\%$ & & \\
\hline \multicolumn{7}{|l|}{ FAIXA ETÁRIA } \\
\hline Adolescente (12-19 anos) & 8 & 15,7 & 18 & 34,6 & 5,859 & $=0,05$ \\
\hline Jovem Adulto (19-21 anos) & 23 & 45,1 & 22 & 42,3 & & \\
\hline Adulto (+ de 21 anos) & 20 & 39,2 & 12 & 23,1 & & \\
\hline \multicolumn{7}{|l|}{ SEXO } \\
\hline Masculino & 32 & 61,5 & 27 & 51,9 & 0,979 & NS \\
\hline Feminino & 20 & 38,5 & 25 & 48,1 & & \\
\hline \multicolumn{7}{|l|}{ OPÇÃO SEXUAL } \\
\hline Heterossexual & 34 & 66,7 & 39 & 78,0 & & \\
\hline Homossexual & 7 & 13,7 & 7 & 14,0 & 2,904 & NS \\
\hline Bissexual & 10 & 19,6 & 4 & $\mathbf{8 , 0}$ & & \\
\hline \multicolumn{7}{|l|}{ ESTADO CIVIL } \\
\hline Solteiro & 45 & 86,5 & 45 & 86,5 & & \\
\hline Casado & 5 & 9,6 & 4 & 7,7 & 0,311 & NS \\
\hline Separado & 2 & 3,8 & 3 & 5,8 & & \\
\hline \multicolumn{7}{|l|}{ ESCOLARIDADE } \\
\hline Primário/ginásio & 19 & 5,8 & 18 & 7,7 & & \\
\hline Colegial & 2 & 34,6 & 4 & 34,6 & 0,159 & NS \\
\hline Universitário & 31 & 59,6 & 30 & 57,7 & & \\
\hline \multicolumn{7}{|l|}{ OCUPAÇÃO ** } \\
\hline Trabalho fixo & 25 & 48,1 & 24 & 46,2 & 0,039 & NS \\
\hline Free lancer/bicos & 24 & 46,2 & 14 & 26,9 & 4,147 & $<0,05$ \\
\hline Estudante & 22 & 42,3 & 33 & 63,5 & 4,669 & $<0,05$ \\
\hline Desempregado & 4 & 7,7 & 8 & 15,4 & 1,507 & NS \\
\hline \multicolumn{7}{|l|}{ CLASSE SÓCIO-ECONÔMICA } \\
\hline Alta ou média/alta & 13 & 25,5 & 9 & 23,5 & & \\
\hline Média & 26 & 51,0 & 30 & 58,8 & 3,356 & NS \\
\hline Média/baixa ou baixa & 12 & 23,5 & 12 & 17,6 & & \\
\hline
\end{tabular}

* $\mathrm{N}$ e \% não incluem respostas em branco ** Era possível assinalar mais de uma alternativa 
Na Tabela 6 são apresentados os dados com relação à renda mensal e ao gasto semanal "para sair". Observa-se que no grupo dos usuários as medianas de ambas as variáveis foram o dobro das medianas obtidas no grupo de não usuários, embora os dois grupos tenham apresentado mínimas e máximas semelhantes. Assim, a renda e o gasto semanal "para sair" entre os usuários são significativamente superiores aos dos não usuários. As respostas de ambas as questões foram segmentadas em quartis, os quais quando comparados, resultam em diferenças também significativas para as duas variáveis.

Tabela 6. Renda mensal e gasto semanal "para sair" de usuários e de não usuários

\begin{tabular}{|c|c|c|c|c|c|}
\hline & & USUÁRIOS & NÃO USUÁRIOS & ESTATÍSTICA & $p$ \\
\hline RENDA & MENSAL (R\$) & (\%) & (\%) & \multirow{5}{*}{$\chi^{2}=7,677$} & \multirow{5}{*}{$=0,05$} \\
\hline & 0 a 300 & 14,6 & 39,0 & & \\
\hline & 301 a 800 & 24,4 & 24,4 & & \\
\hline & 801 а 1500 & 36,6 & 17,1 & & \\
\hline & acima de 1500 & 24,4 & 19,5 & & \\
\hline & Mínima & 0,00 & 40,00 & \multirow{3}{*}{$U=631,00$} & \multirow{3}{*}{$<0,05$} \\
\hline & Máxima & 6000,00 & 6000,00 & & \\
\hline & Mediana & 1000,00 & 500,00 & & \\
\hline GASTO & SEMANAL & $(\%)$ & $(\%)$ & \multirow{6}{*}{$\chi^{2}=10,974$} & \multirow{6}{*}{$<0,05$} \\
\hline "PARA & SAIR" (R\$) & & & & \\
\hline & 0 a 40 & 14,6 & 39,6 & & \\
\hline & 41 а 50 & 22,9 & 27,1 & & \\
\hline & 51 a 100 & 37,5 & 14,6 & & \\
\hline & acima de 100 & 25,0 & 18,8 & & \\
\hline & Mínima & 0 & 10,00 & \multirow{3}{*}{$U=790,00$} & \multirow{3}{*}{$<0,01$} \\
\hline & Máxima & 300,00 & 400,00 & & \\
\hline & Mediana & 100,00 & 50,00 & & \\
\hline
\end{tabular}

\section{Outras características de usuários e de não usuários}

A Tabela 7 mostra outras características peculiares a usuários e não usuários: relacionamento com os pais, religião e importância da religião na vida. Em relação a relacionamento com os pais, a maioria dos entrevistados de ambos os grupos o avalia como "bom ou muito bom" entretanto, 5,8\% dos usuários habituais julgam o relacionamento com seus pais "ruim ou muito ruim", alternativa que não foi assinalada por nenhum sujeito dos não usuários. Essa 
diferença, porém, não foi significativa. Em relação à religião, o grupo controle afirma com maior frequência ter religião, diferença estatisticamente significativa, e também a considera mais importante do que o grupo de usuários, diferença que não foi significativa.

Tabela 7. Relacionamento dos usuários e não usuários com os pais e com a religião.

\begin{tabular}{lcccccc}
\hline & USUÁRIOS & NÃO USUÁRIOS & & \\
& $\mathrm{N}$ & $\mathbf{\%}$ & $\mathrm{N}$ & $\mathbf{\%}$ & $\chi^{2}=$ & $\boldsymbol{p}$ \\
\hline RELACIONAMENTO C/ OS PAIS & & & & & & \\
$\quad$ Bom ou muito bom & 33 & $\mathbf{6 3 , 5}$ & 39 & $\mathbf{7 5 , 0}$ & & \\
$\quad$ Mais ou menos & 16 & $\mathbf{3 0 , 8}$ & 13 & $\mathbf{2 5 , 0}$ & 3,810 & NS \\
$\quad$ Ruim ou muito ruim & 3 & $\mathbf{5 , 8}$ & 0 & $\mathbf{0}$ & & \\
\hline RELIGĨ̃O & & & & & & \\
$\quad$ Não tem & 29 & $\mathbf{5 5 , 8}$ & 16 & $\mathbf{3 0 , 8}$ & 6,620 & \multirow{2}{*}{$\mathbf{0 , 0 1}$} \\
$\quad$ Tem & 23 & $\mathbf{4 4 , 2}$ & 36 & $\mathbf{6 9 , 2}$ & & \\
\hline IMPORTÂNCIA DA RELIGIÃO & & & & & & \\
$\quad$ Pouco ou nada importante & 27 & $\mathbf{5 2 , 9}$ & 19 & $\mathbf{3 6 , 6}$ & 2,940 & NS \\
$\quad$ Muito importante ou importante & 24 & $\mathbf{4 7 , 0}$ & 33 & $\mathbf{6 3 , 4}$ & & \\
\hline
\end{tabular}

Na Tabela 8, é apresentada a frequência absoluta e percentual de tatuagens e piercings e a preferência em relação ao estilo musical de usuários e não usuários. Verifica-se que os usuários possuem mais tatuagens e mais piercings do que não usuários, resultados que foram estatisticamente significativos. Também foi significativa a diferença em relação à preferência musical, os usuários preferem música techno (também denominada música eletrônica, aqui englobando drum'n'bass, trance, techno trance) 
Tabela 8. Frequência absoluta e percentual de tatuagens e piercings e preferência em relação ao estilo musical no grupo de usuários e de não usuários.

\begin{tabular}{|c|c|c|c|c|c|c|}
\hline & \multicolumn{2}{|c|}{ USUÁRIOS } & \multicolumn{2}{|c|}{ NÃO USUÁRIOS } & \multirow[b]{2}{*}{$\chi^{2}=$} & \multirow[b]{2}{*}{$p$} \\
\hline & $\mathrm{N}$ & $\%$ & $\mathrm{~N}$ & $\%$ & & \\
\hline \multicolumn{7}{|l|}{ TATUAGEM } \\
\hline Não tem & 16 & 31,4 & 37 & 72,5 & 17,321 & $<\mathbf{0 , 0 1}$ \\
\hline Tem & 35 & 68,6 & 14 & 27,5 & & \\
\hline \multicolumn{7}{|l|}{ PIERCING } \\
\hline Não tem & 20 & 39,2 & 31 & 59,6 & 4,286 & $<0,05$ \\
\hline Tem ou já teve & 31 & 60,8 & 21 & 40,4 & & \\
\hline \multicolumn{7}{|l|}{ PREFERÊNCIA MUSICAL } \\
\hline Eclético/não tem preferências & 6 & 12,0 & 7 & 13,5 & & \\
\hline Prefere música techno & 29 & 58,0 & 12 & 23,1 & 22,831 & $<0,01$ \\
\hline Techno está entre as preferidas & 13 & 26,0 & 12 & 23,1 & & \\
\hline Techno não está entre as preferidas & 2 & 4,0 & 21 & 40,4 & & \\
\hline
\end{tabular}

A Figura 2 mostra os locais frequentados pelos dois grupos, dentre lugares para dançar, bares, festas, shows, exposições de arte e raves. Verifica-se que os usuários comparecem mais assiduamente a lugares para dançar, festas e raves do que os não usuários, e estes tendem a frequentar mais bares e shows do que os usuários. Em relação a exposições de arte e museus a frequência dos dois grupos é mais baixa e muito semelhante. A única diferença significativa $\left(\chi^{2}=25,009 ; p<0,01\right)$ aparece com relação às raves, e nesse caso a assiduidade dos usuários é expressivamente superior. 
Lugares para dançar

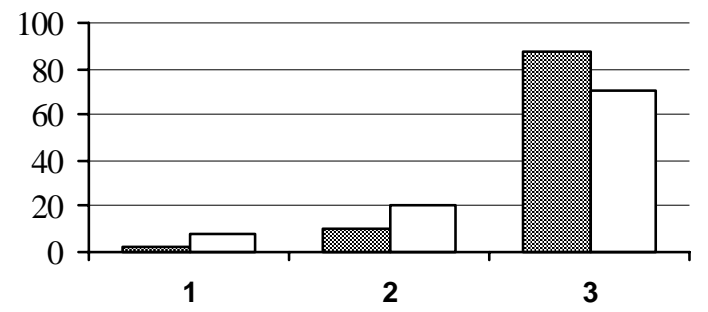

Festas
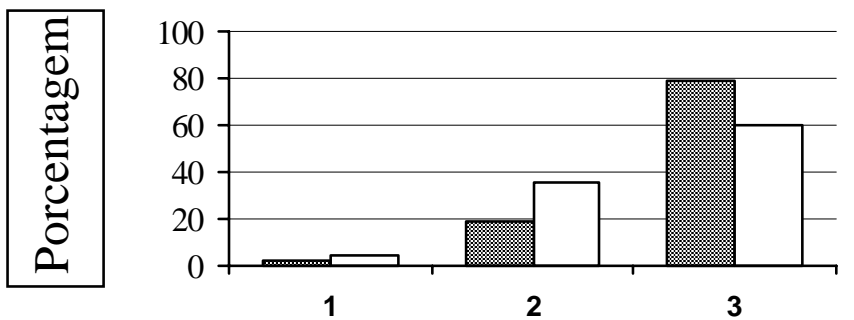

Shows

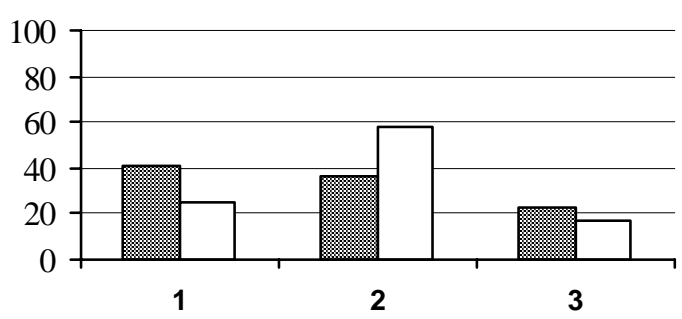

Bares

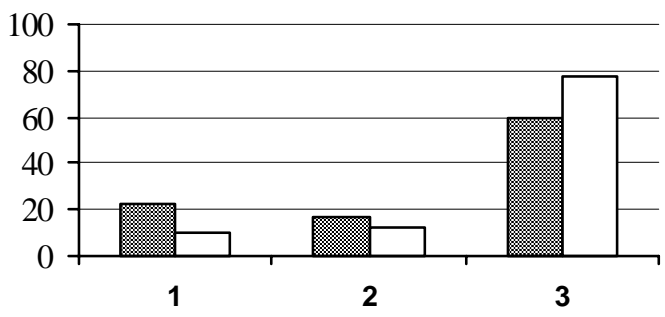

Raves

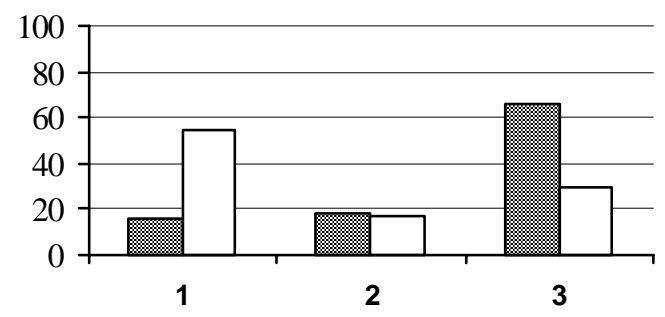

Exposições de arte/Museus

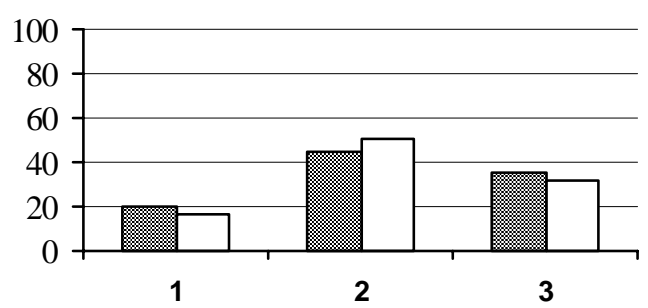

Frequência aos locais

\section{Usuários $\square$ Não usuários}

Figura 2. Frequência percentual de respostas à pergunta "Com que frequência você vai aos seguintes lugares?" (1= Raramente ou nunca; $\mathbf{2}=$ Mais ou menos uma vez por mês; $\mathbf{3}=$ Mais que uma vez por mês). 


\section{Dados da relação de usuários e de não usuários com drogas psicotrópicas}

Seguem os resultados descritivos para as respostas referentes às questões que identificam o consumo e os padrões de comportamento em relação a drogas psicotrópicas. A Tabela 9 mostra a frequência do relato ficar bêbado(a) no mês antecedente à entrevista. Em relação ao uso de álcool as maiores diferenças aparecem nas alternativas "ficar bêbado(a) nenhuma vez no último mês", opção assinalada por 45,1\% dos usuários e 34,6\% dos não usuários; e na alternativa "ficar bêbado(a) algumas vezes por mês" que é assinalada por 27,5\% dos usuários e por 40,4\% dos não usuários. Não há porém diferença estatisticamente significativa entre as populações de usuários e não usuários.

Tabela 9. Frequência absoluta e percentual de respostas à pergunta: "Aproximadamente quantas vezes você ficou bêbado(a) no último mês?”

\begin{tabular}{lcccccc}
\hline & \multicolumn{2}{c}{ USUÁRIOS } & NÃO USUÁRIOS & & \\
& $\mathrm{N}$ & $\mathbf{\%}$ & $\mathrm{N}$ & $\mathbf{\%}$ & $\chi^{2}$ & $\boldsymbol{p}$ \\
\hline Nenhuma vez & 23 & $\mathbf{4 5 , 1}$ & 18 & $\mathbf{3 4 , 6}$ & & \\
Uma vez & 9 & $\mathbf{1 7 , 6}$ & 7 & $\mathbf{1 3 , 5}$ & & \\
Algumas vezes & 14 & $\mathbf{2 7 , 5}$ & 21 & $\mathbf{4 0 , 4}$ & 2,393 & NS \\
Várias vezes/semana & 3 & $\mathbf{5 , 9}$ & 4 & $\mathbf{7 , 7}$ & & \\
Todos ou quase todos os dias & 2 & $\mathbf{3 , 9}$ & 2 & $\mathbf{3 , 8}$ & & \\
\hline
\end{tabular}

Em relação ao uso de substâncias psicotrópicas na vida (Figura 3), constata-se que a grande maioria dos entrevistados de ambos os grupos já teve contato com vários tipos de droga. Entretanto, a proporção de uso no grupo de usuários de "êxtase" é maior para todas as drogas relacionadas, além de que todas as diferenças de uso de drogas na vida entre usuários e não usuários são significativas, exceto para o álcool. 


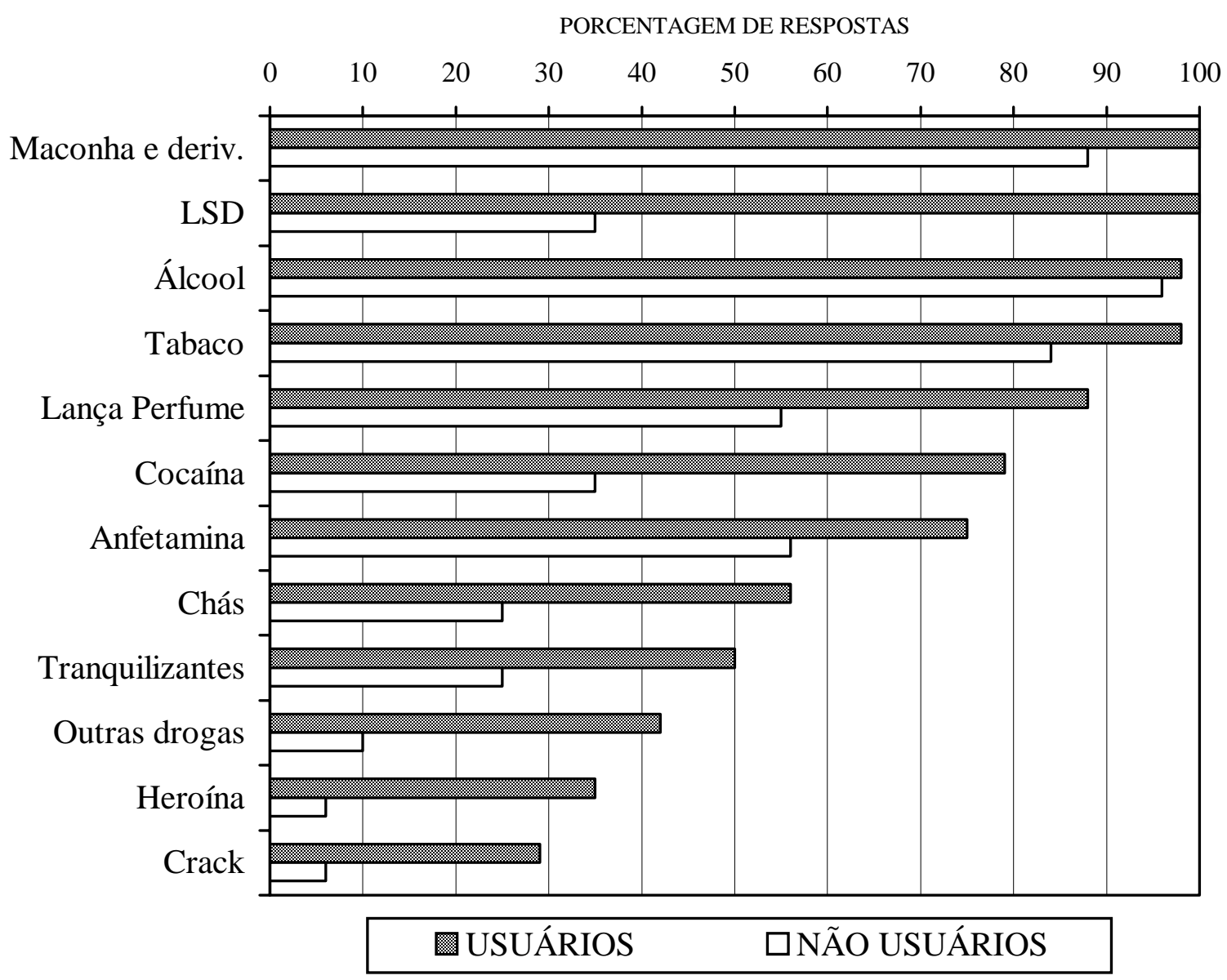

Figura 3. Frequência percentual de respostas à pergunta: "Quais substâncias da lista abaixo você usou pelo menos uma vez na vida?"

Também em relação ao uso de drogas no mês antecedente à entrevista há uma maior proporção de usuários para todas as drogas relacionadas exceto para o álcool: houve mais não usuários que declararam tê-lo consumido (Figura 4). As diferenças no consumo de drogas no último mês são significativas para: maconha e derivados, tabaco, LSD, cocaína, chás de lírio ou cogumelo e outras drogas. 
PORCENTAGEM DE RESPOSTAS

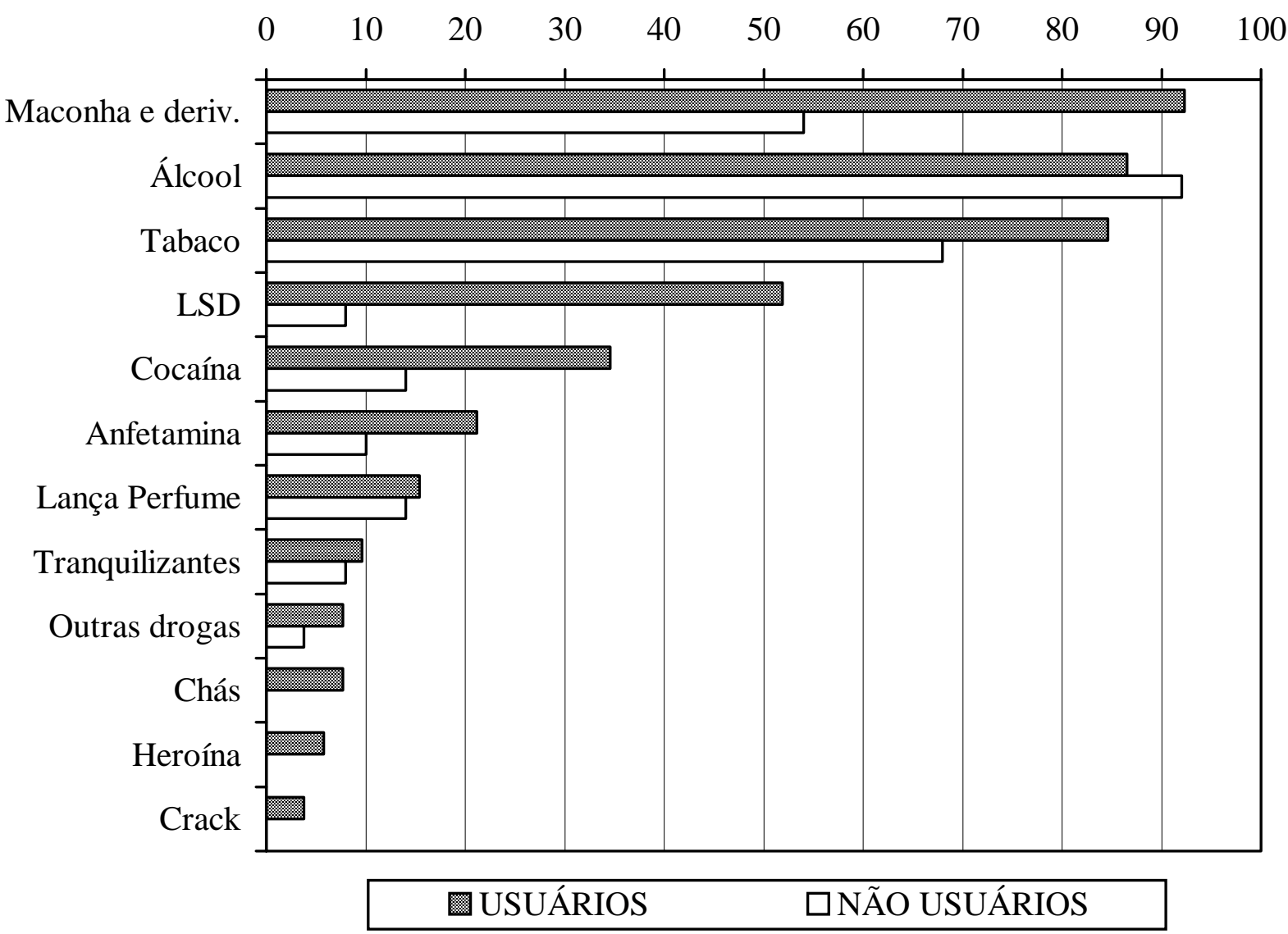

Figura 4. Frequência percentual de respostas à pergunta: "Quais substâncias da lista abaixo você usou pelo menos uma vez durante o último mês?"

Ainda em relação ao uso de substâncias psicoativas utilizadas no mês antecedente à entrevista, foi feita uma análise na qual os dados foram agrupados de acordo com o número de diferentes drogas utilizadas. O resultado apresentado na Figura 4 mostra que entre os usuários de êxtase 34\% usaram mais de cinco tipos de drogas psicoativas no último mês contra somente 6\% dos não usuários, enquanto 1,9\% dos usuários usaram apenas uma droga no último mês contra 18\% na amostra de não usuários. Essas diferenças são novamente significativas $\left(\chi^{2}=17,434 ; p<0,001\right)$. 


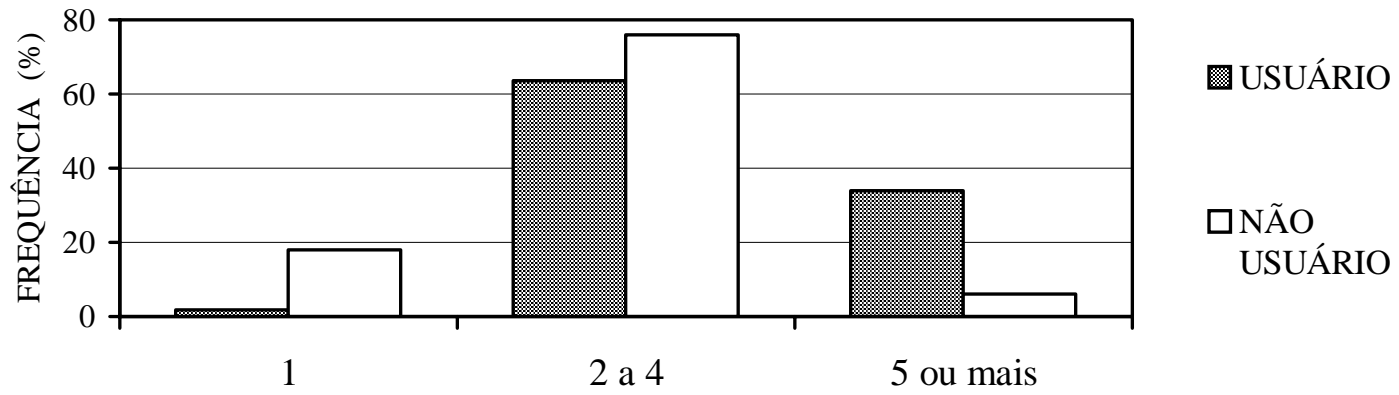

Figura 6. Frequência percentual de sujeitos de cada grupo em função do número de drogas utilizadas no último mês.

A Tabela 9 mostra a proporção de respostas de usuários e de não usuários às alternativas da questão "Você já pensou em parar de usar alguma droga?". Nota-se que 71,2\% dos usuários já pensaram em parar de usar alguma droga e 28,8\% nunca pensaram. Na amostra controle essas proporções foram de $56 \%$ e $18 \%$ respectivamente, sendo que os $26 \%$ complementares afirmam não usar drogas. A diferença entre os dois grupos é estatisticamente significativa. Entretanto, se na amostra controle considerarmos apenas as respostas de quem utiliza drogas, essas proporções seriam respectivamente $75,6 \%$ e $24,3 \%$, muito próximas das observadas entre os usuários e portanto não representando diferenças entre os dois grupos.

Tabela 9. "Você já pensou em parar de usar alguma droga?”

\begin{tabular}{lcccccc}
\hline & \multicolumn{2}{c}{ USUÁRIOS } & NÃO USUÁRIOS & & \\
& $\mathrm{N}$ & $\mathbf{\%}$ & $\mathrm{N}$ & $\mathbf{\%}$ & $\chi^{2}$ & $\boldsymbol{p}$ \\
\hline Não uso drogas & 0 & $\mathbf{0}$ & 13 & $\mathbf{2 6 , 0}$ & & \\
Nunca pensei & 15 & $\mathbf{2 8 , 8}$ & 9 & $\mathbf{1 8 , 0}$ & 15,713 & $<\mathbf{0 , 0 1}$ \\
Já pensei & 37 & $\mathbf{7 1 , 2}$ & 28 & $\mathbf{5 6 , 0}$ & & \\
\hline
\end{tabular}

Embora ambos os grupos apresentem proporções semelhantes em relação à quantidade de problemas que o uso de "êxtase" pode gerar, a ordem dos problemas apontados é diferente nos dois grupos (Tabela 10). Enquanto que o problema apontado com maior frequência pelo grupo de usuários é a possível adulteração do comprimido, os não usuários apontam com maior frequência os danos que o uso de "êxtase" pode fazer à saúde. 
Tabela 10: Frequência percentual de respostas à questão "Você acha que tomar "êxtase" pode trazer problemas para quem usa?"

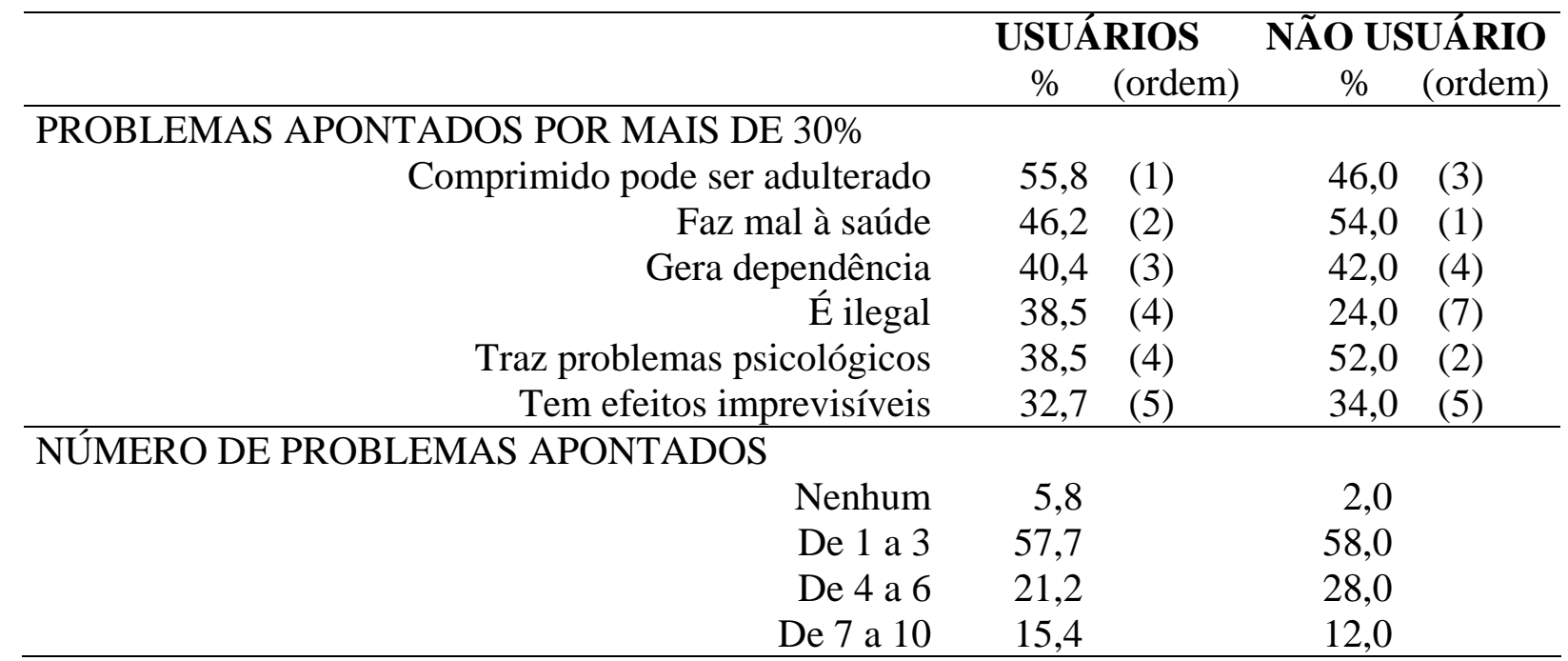

No grupo de usuários há uma nítida predominância de amigos que também usam "êxtase", enquanto que entre os não usuários a maioria dos entrevistados têm apenas alguns amigos que usam a droga. É importante ressaltar que não ter amigos que utilizassem "êxtase" foi um critério de exclusão de não usuários. A diferença entre os dois grupos é estatisticamente significativa (Tabela 11).

Tabela 11. Frequência percentual de respostas à questão "Quantos de seus amigos tomam "êxtase"?"

\begin{tabular}{lcccccc}
\hline & USUÁRIOS & NÃO USUÁRIOS & & \\
& $\mathrm{N}$ & $\mathbf{\%}$ & $\mathrm{N}$ & $\mathbf{\%}$ & $\chi^{2}=$ & $\boldsymbol{p}$ \\
\hline A maioria ou todos & 33 & $\mathbf{6 3 , 5}$ & 9 & $\mathbf{1 7 , 3}$ & & \\
Mais ou menos a metade & 13 & $\mathbf{2 5 , 0}$ & 6 & $\mathbf{1 1 , 5}$ & 38,642 & $<\mathbf{0 , 0 1}$ \\
Alguns & 6 & $\mathbf{1 1 , 5}$ & 37 & $\mathbf{7 1 , 2}$ & & \\
\hline
\end{tabular}

Aos não usuários foi perguntado porque eles nunca tinham experimentado "êxtase" e os três principais motivos apontados foram: "falta de oportunidade" (34,6\%), "falta de vontade ou curiosidade" (23,1\%) e "medo de experimentar" (15,4\%). 


\section{Análise descritiva dos padrões de uso de "êxtase" pelos usuários}

Em relação à idade em que o sujeito usou "êxtase” pela primeira vez verifica-se que 47,1\% dos usuários entrevistados experimentaram "êxtase" entre 18 e 22 anos, 27,5\% com menos de 18 anos e 25,5\% com 23 ou mais. A idade mínima de uso pela primeira vez foi de 14 anos e a idade máxima de 34 anos. Em relação ao tempo de uso 54\% usaram "êxtase" pela primeira vez entre dois e quatro anos antes da entrevista. Esses resultados são apresentados nas Figuras 6 e 7.

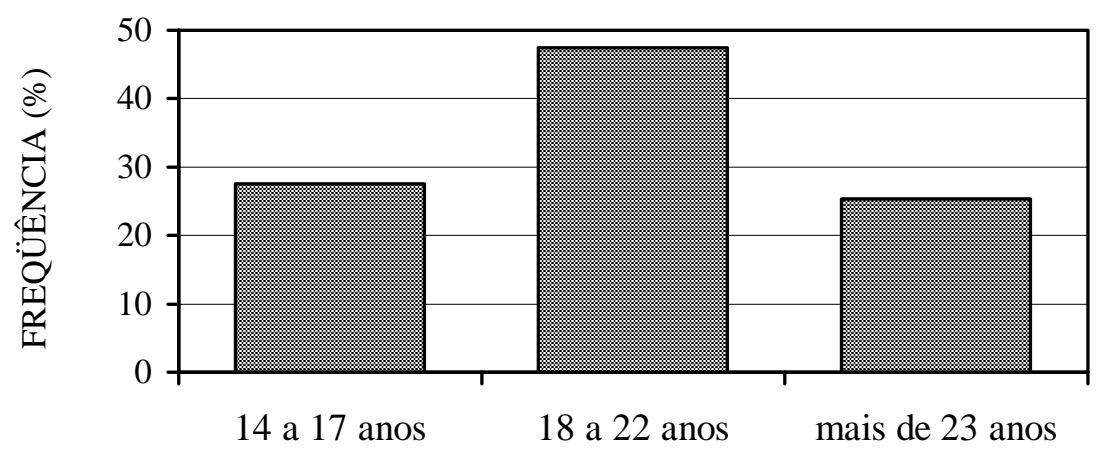

Figura 6. Frequência percentual de respostas à questão " Quantos anos você tinha quando usou "êxtase" pela $1^{\underline{a}}$ vez?".

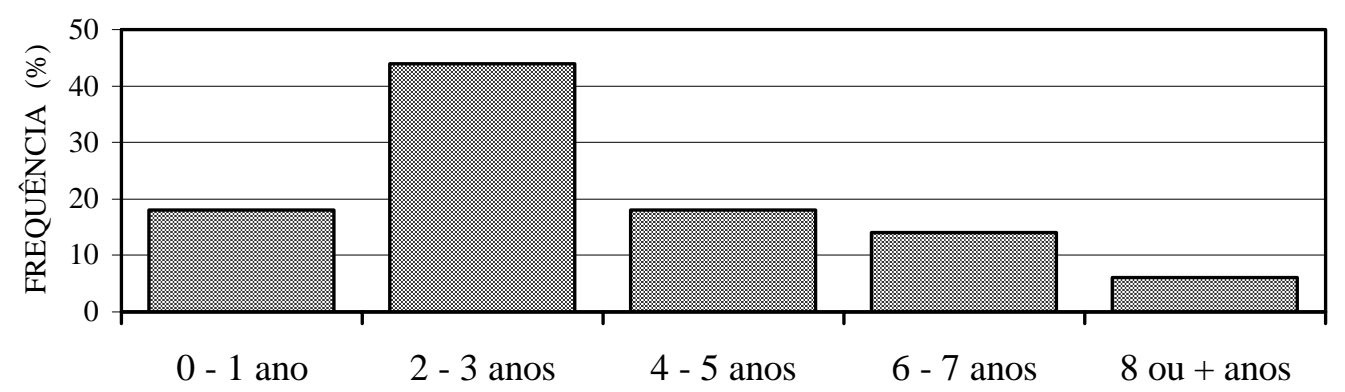

Figura 7: Diferença entre idade em que experimentou "êxtase" pela $1^{\mathrm{a}}$ vez e idade atual.

Em relação à composição do comprimido 78\% dos usuários preferem saber o que estão tomando, embora tomem o comprimido mesmo quando não o sabem, 14\% dizem preferir não tomar quando não sabem sua composição e $8 \%$ assinalaram que não é importante saber a composição do que tomam. Dos usuários entrevistados, $50 \%$ tomam geralmente um comprimido a cada episódio de uso, $46 \%$ tomam mais de um e $4 \%$ tomam menos de um 
comprimido. A frequência de uso de "êxtase" no último mês e nos últimos três meses encontra-se na Tabela 12.

Tabela 12. Frequência percentual de uso de "êxtase" durante o último mês e nos últimos três meses.

\begin{tabular}{lcc}
\hline & ÚLTIMO MÊS (\%) & ÚLTIMOS 3 MESES (\%) \\
\hline No máximo 1 vez/mês & 38,5 & 36,5 \\
No máximo 1 vez/semana & 38,5 & 42,3 \\
Mais de 1 vez/semana & 23,1 & 21,2 \\
\hline
\end{tabular}

Ainda em relação aos padrões de consumo a grande maioria afirma que normalmente toma "êxtase" apenas nos finais de semana ou férias (82,7\%) e mais frequentemente na companhia de várias pessoas (63,5\%). Em ordem decrescente os usuários costumam tomar a droga em raves $(78,8 \%)$, em lugares para dançar (69,2\%), em festas (53,8\%), em casa $(34,6 \%)$, em bares $(3,8 \%)$ e na rua $(1,9 \%)$.

A média do preço de um comprimido foi de $\mathrm{R}$ \$31,30, sendo que três sujeitos disseram não saber o preço. A maioria dos entrevistados, 53,1\%, compra a droga de amigos ou conhecidos, 20,4\% compra de amigos ou conhecidos e também de alguém que faz tráfico, e 18,4\% compra de alguém que faz tráfico. Em ordem decrescente os usuários compram "êxtase" em raves (59,2\%), em festas (44,9\%), em bares ou lugares para dançar (40,8\%), em outros lugares como por exemplo na casa de amigos ou do traficante (36,7\%), e por telefone (4\%).

Dos usuários entrevistados, 50\% disse já ter pensado em parar de usar "êxtase", 48,2\% disse nunca ter pensado nisso e um sujeito disse não usar mais "êxtase" embora tenha usado mais de dez vezes e o tenha feito há menos de um mês. Na Tabela 13 está indicada a porcentagem de respostas à pergunta sobre as razões para tomar "êxtase". Nota-se que dançar é de longe o principal motivo apontado pelos usuários. 
Tabela 13. Frequência percentual de respostas à questão "Quais são as principais razões para você usar "êxtase"?"

\begin{tabular}{lc}
\hline \multicolumn{1}{c}{ RAZÕES } & $\%(*)$ \\
\hline Dançar & 82,7 \\
Relaxar & 53,8 \\
Estimular os sentidos & 44,2 \\
Sentir-se mais feliz & 38,5 \\
Sentir-se melhor com os outros & 25,0 \\
Fugir da realidade ou esquecer problemas & 23,1 \\
Transar & 19,2 \\
Estimular a criatividade & 17,3 \\
Desinibir & 9,6 \\
\hline
\end{tabular}

(*) Era possível assinalar mais de uma alternativa

Apenas 7,7\% dos usuários entrevistados disseram que não costumam usar outras drogas enquanto o "êxtase" está fazendo efeito. Os outros costumam combiná-lo com outros psicotrópicos, especialmente maconha e similares, e tabaco, conforme mostra a Tabela 14.

Tabela 14. Frequência relativa de respostas sobre as diversas substâncias utilizadas enquanto o "êxtase" está fazendo efeito.

\begin{tabular}{ll}
\hline \multicolumn{1}{c}{ SUBSTÂNCIA } & $\mathbf{\% ( * )}$ \\
\hline Maconha e similares (special K/charras/haxixe) & 82,7 \\
Cigarro & 61,5 \\
LSD & 30,8 \\
Álcool & 26,9 \\
Cocaína ou craca & 17,3 \\
Anfetamina & 5,8 \\
Outras drogas (opiáceo/lança-perfume/cigarro de cravo) & 5,8 \\
\hline
\end{tabular}

(*) Era possível assinalar mais de uma alternativa

\section{Efeitos do "êxtase" assinalados pelos usuários}

Em relação aos efeitos, nenhum dos sujeitos pesquisados afirmou que os efeitos do "êxtase" eram na maior parte das vezes negativos, enquanto 32,7\% afirmaram que eram tanto positivos quanto negativos e 67,3\% disseram que os efeitos eram positivos. A tabela 15 mostra a 
porcentagem de sujeitos que assinalou cada item da questão "Da lista abaixo assinale como você se sente durante o efeito do êxtase".

Tabela 15. Frequência percentual e absoluta com que possíveis efeitos do "êxtase" foram assinalados

\begin{tabular}{|c|c|c|}
\hline EFEITO & $\mathrm{N}$ & $(\%)$ \\
\hline FELIZ & 47 & 92.2 \\
\hline COM ENERGIA & 43 & 84.3 \\
\hline AMOROSO & 42 & 82.4 \\
\hline MAIS PRÓXIMO DAS OUTRAS PESSOAS & 40 & 78.4 \\
\hline FICO À VONTADE & 40 & 78.4 \\
\hline EM PAZ & 38 & 74.5 \\
\hline COM TESÃO & 37 & 72.5 \\
\hline MENTE ABERTA & 36 & 70.6 \\
\hline DESPREOCUPADO & 35 & 68.6 \\
\hline CALMO & 34 & 66.7 \\
\hline ABERTO AO MEIO AMBIENTE & 32 & 62.7 \\
\hline COM A BOCA SECA & 32 & 62.7 \\
\hline SENSUAL & 30 & 58.8 \\
\hline COM ONDAS DE FRIO OU CALOR & 30 & 58.8 \\
\hline ÍNTIMO DAS PESSOAS & 29 & 56.9 \\
\hline SEM APETITE & 29 & 56.9 \\
\hline SEM SONO & 28 & 54.9 \\
\hline COM PUPILAS DILATADAS & 27 & 52.9 \\
\hline COM TENSÃO NO MAXILAR & 26 & 51.0 \\
\hline EUFÓRICO & 25 & 49.0 \\
\hline EMOTIVO & 25 & 49.0 \\
\hline COM TATO ESTIMULADO & 25 & 49.0 \\
\hline ESPIRITUAL & 24 & 47.1 \\
\hline RANGENDO OS DENTES & 23 & 45.1 \\
\hline COM O CORAÇÃO ACERELADO & 23 & 45.1 \\
\hline NOÇÃO DE TEMPO ALTERADO & 21 & 41.2 \\
\hline SEXUAL & 20 & 39.2 \\
\hline AGITADO & 20 & 39.2 \\
\hline AUTO CONFIANTE & 19 & 37.3 \\
\hline ILUMINADO & 18 & 35.3 \\
\hline SUANDO NAS PALMAS DAS MÃOS & 18 & 35.3 \\
\hline COM A AUTO ESTIMA AUMENTADA & 17 & 33.3 \\
\hline SEGURO & 17 & 33.3 \\
\hline COM VONTADE DE URINAR & 17 & 33.3 \\
\hline COM PENSAMENTO CLARO & 16 & 31.4 \\
\hline VOLTADO PARA O AQUI E AGORA & 16 & 31.4 \\
\hline TENHO ALUCINAÇÕES AUDITIVAS & 16 & 31.4 \\
\hline COM A PERSEPÇÃO AGUÇADA & 16 & 31.4 \\
\hline TENHO SUOR GENERALIZADO & 15 & 29.4 \\
\hline TENHO ALUCINAÇÕES VISUAIS & 15 & 29.4 \\
\hline FALANTE & 13 & 25.5 \\
\hline TENHO INSIGHTS & 13 & 25.5 \\
\hline DESCOORDENADO & 13 & 25.5 \\
\hline
\end{tabular}

\begin{tabular}{|c|c|c|}
\hline EFEITO & $\mathrm{N}$ & $(\%)$ \\
\hline ANSIOSO & 12 & 23.5 \\
\hline ALERTA & 11 & 21.6 \\
\hline COM DIFICULDADE DE CONCENTRAÇÃO & 11 & 21.6 \\
\hline ATENTO & 10 & 19.6 \\
\hline PENSO NO PASSADO OU FUTURO & 10 & 19.6 \\
\hline COM PENSAMENTOS ESTRANHOS & 9 & 17.6 \\
\hline PERCO A NOÇÃO DO REAL & 9 & 17.6 \\
\hline COM DORES MUSCULARES & 8 & 15.7 \\
\hline CONFUSO & 8 & 15.7 \\
\hline COM NÁUSEA & 7 & 13.7 \\
\hline TENHO VÔMITOS & 7 & 13.7 \\
\hline COM A VISÃO TURVA & 7 & 13.7 \\
\hline PREOCUPADO COM O QUE PENSAM DE MIM & 6 & 11.8 \\
\hline NERVOSO & 5 & 9.8 \\
\hline TENSO & 5 & 9.8 \\
\hline PARANÓICO & 5 & 9.8 \\
\hline SOLITÁRIO & 5 & 9.8 \\
\hline TENHO PALPITAÇÕES & 5 & 9.8 \\
\hline COM TREMORES & 5 & 9.8 \\
\hline COM FORMIGAMENTOS & 5 & 9.8 \\
\hline DESORIENTADO & 5 & 9.8 \\
\hline PREOCUPADO & 4 & 7.8 \\
\hline INSEGURO & 4 & 7.8 \\
\hline ISOLADO & 4 & 7.8 \\
\hline COM MEDO & 4 & 7.8 \\
\hline COM A CABEÇA LATEJANDO & 4 & 7.8 \\
\hline TRISTE & 3 & 5.9 \\
\hline SEM ENERGIA & 3 & 5.9 \\
\hline INFERIOR & 2 & 3.9 \\
\hline COM TONTURA & 2 & 3.9 \\
\hline EM PÂNICO & 2 & 3.9 \\
\hline MENTALMENTE INSTÁVEL & 2 & 3.9 \\
\hline IRRITÁVEL & 2 & 3.9 \\
\hline DEPRIMIDO & 2 & 3.9 \\
\hline APÁTICO & 2 & 3.9 \\
\hline COM RAIVA & 1 & 2.0 \\
\hline COM DORES DE CABEÇA & 1 & 2.0 \\
\hline TENHO ESPASMOS OU CONVULSÕES & 1 & 2.0 \\
\hline
\end{tabular}

Foi feita uma comparação entre os efeitos assinalados por usuários que afirmaram que os efeitos do "êxtase" eram exclusivamente positivos e os que afirmaram que os efeitos eram positivos e negativos. A comparação encontra-se na Tabela 16 e teve por objetivo verificar a confiabilidade da atribuição do caráter positivo ou negativo aos efeitos. 
Tabela 16: Efeitos mais frequentemente assinalados pelo conjunto de usuários que julgou os efeitos exclusivamente positivos e pelo conjunto de usuários que julgou os efeitos como positivos e negativos.

\begin{tabular}{ll}
\hline $\begin{array}{c}\text { Efeitos são positivos (N=35) } \\
(\%)\end{array}$ & $\begin{array}{c}\text { Efeitos são positivos e negativos (N=17) } \\
(\%)\end{array}$ \\
& Com energia $(94,1)$ \\
& Feliz $(88,2)$ \\
Feliz $(94,3)$ & Mais próximo dos outros $(88,2)$ \\
Fico à vontade $(85,7)$ & Com a boca seca $(88,2)$ \\
Amoroso $(80,0)$ & Amoroso $(88,2)$ \\
Com energia $(80,0)$ & Com tesão $(82,4)$ \\
Em paz $(80,0)$ & Mente aberta $(76,5)$ \\
Mais próximo dos outros $(74,3)$ & Com o coração acelerado $(76,5)$ \\
Calmo $(71,4)$ & Sem sono $(76,5)$ \\
& Sem apetite $(76,5)$ \\
& Alerta $(70,6)$ \\
& Despreocupado $(70,6)$ \\
& Com ondas de frio e calor $(70,6)$ \\
\hline
\end{tabular}

\section{Escalas psicológicas}

Entre as escalas utilizadas apenas o Inventário de Depressão de Beck diferenciou significativamente usuários de não usuários. A pontuação média e desvios padrão de cada grupo obtidos nessa escala é apresentada na Figura 8. Verifica-se que a média de pontos nesse inventário é mais alta entre os não usuários do que entre os usuários, diferença estatisticamente significativa $(t=2,151 ; p<0,05)$. Entretanto, nota-se que ambas as médias estão dentro do padrão de normalidade, na categoria baixa, isto é, são menores que 16 . A diferença percentual nas categorias baixa $(<16)$, média (16-21) e alta $(>21)$ são apresentadas na Figura 9, não sendo estatisticamente significativa entre os dois grupos $\left(\chi^{2}=4,797 ; p=\right.$ $0,091)$. 


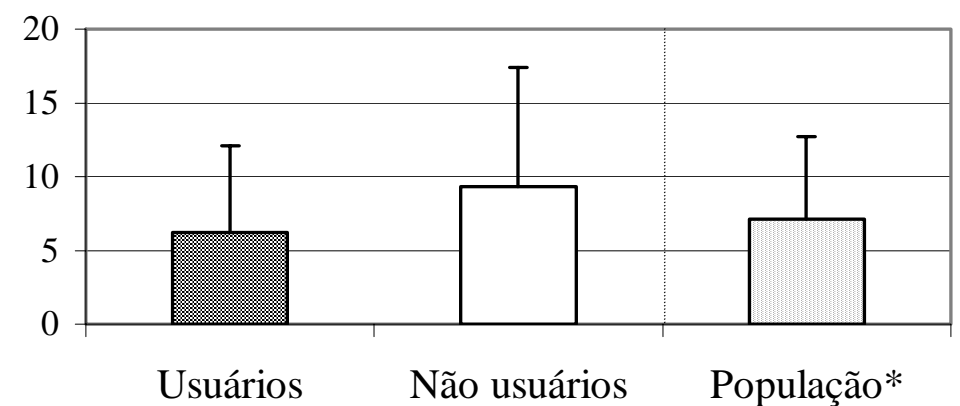

Figura 8. Média e desvio padrão da pontuação de usuários e não usuários no Inventário de Depressão de Beck. (*) A média e desvio padrão da população universitária testada por Gorenstein (Gorenstein, Pompéia, \& Andrade, 1995) é também apresentada.

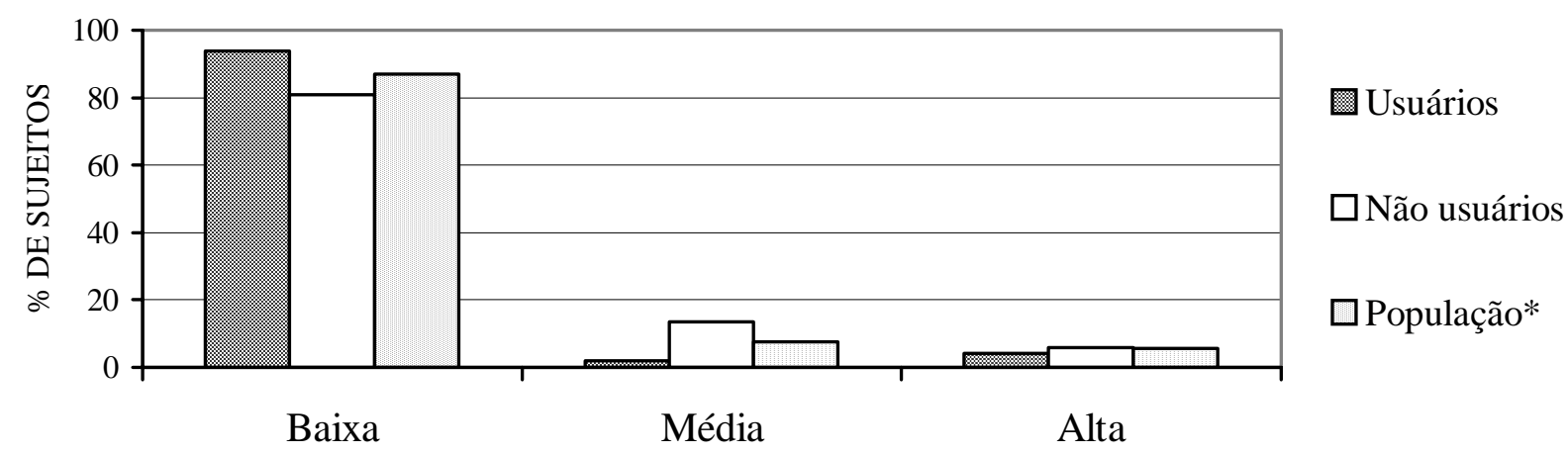

(*) População Universitária (Gorenstein et al., 1995)

Figura 9. Frequência percentual de usuários, não usuários e população universitária brasileira nas categorias Alta, Média e Baixa no Inventário de Depressão de Beck

Na Figura 10 encontram-se as médias e os desvios padrão obtidos na escala IDATE-Traço pelos dois grupos e por população universitária brasileira. As diferenças apresentadas não são significativas $(t=1,556 ; p=0,496)$. Verifica-se que os não usuários apresentaram média de pontos mais alta que os usuários; entretanto, o desvio padrão também é maior devido à presença de três resultados superiores a 60 pontos. A pontuação obtida foi classificada como baixa (<33), média (33-49) e alta (>49) (Gorenstein et al., 1995). As diferenças entre os dois grupos nessas categorias, apresentadas na Figura 11, não são significativas $\left(\chi^{2}=1,90\right.$; $p=0,387)$. 


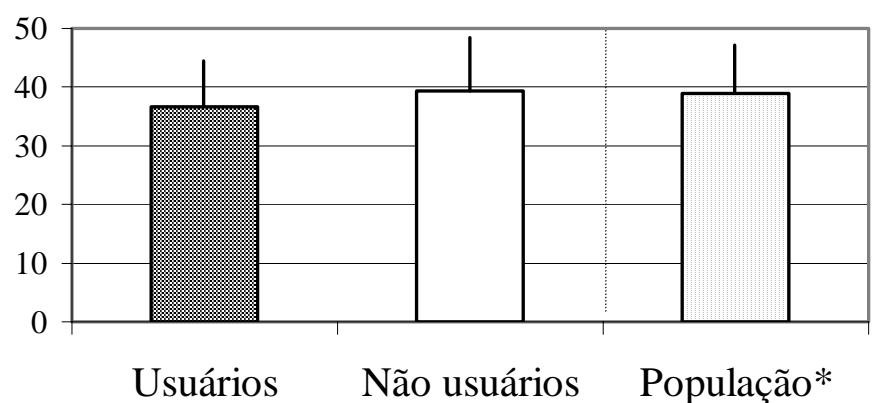

Figura 10. Média e desvio padrão da pontuação de usuários e não usuários na escala IDATETraço. (*) A média e desvio padrão da população universitária estudada por Gorenstein (Gorenstein et al., 1995) também é apresentada.

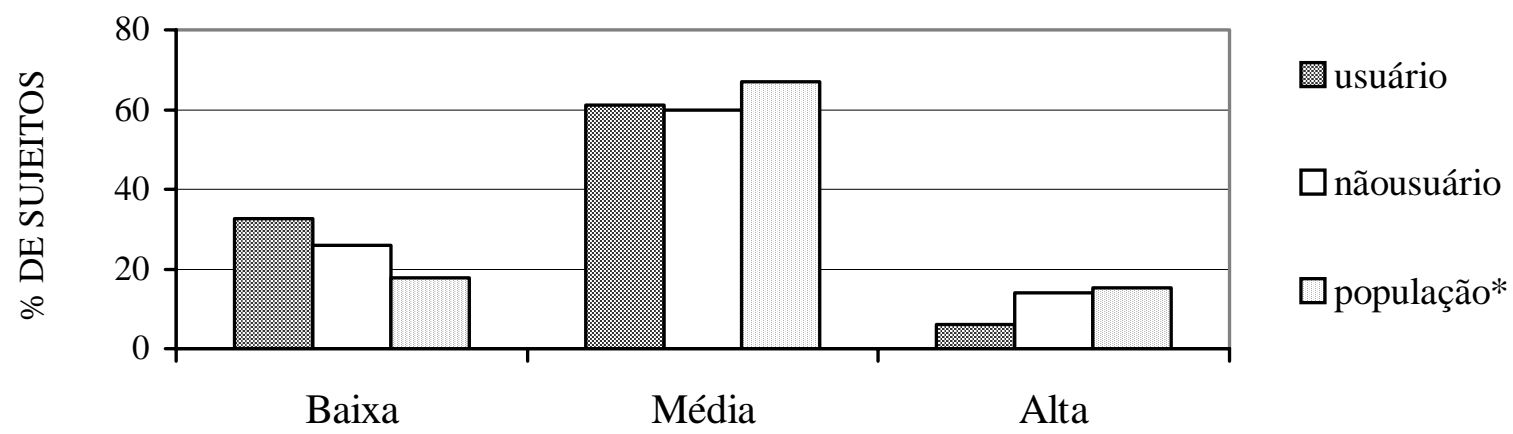

(*) População Universitária (Gorenstein et al., 1995)

Figura 11. Frequência percentual de usuários, não usuários e população universitária brasileira nas categorias alta, média e baixa na escala IDATE-Traço.

Quanto à Barrat Impulsivity Scale (BIS), verifica-se que os grupos apresentam pontuações médias e desvios padrão muito semelhantes, como se pode observar na Tabelas 12. As diferenças não são significativas $(t=0,086 ; p=0,931)$. 


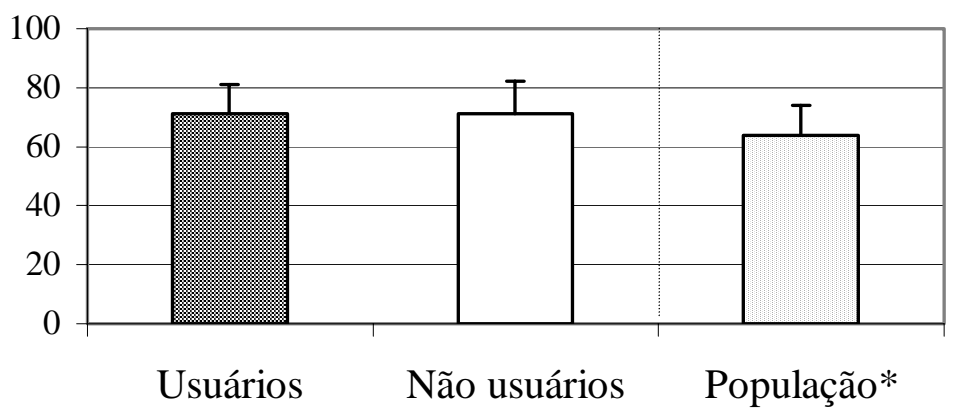

Figura 12. Média e desvio padrão da pontuação de usuários e não usuários na escala BIS (Barrat Impulsivity Scale). (*) A média e desvio padrão da população universitária estudada por Patton (Patton et al., 1995) também é apresentada.

\section{Confiabilidade das Escalas}

Com a finalidade de obter uma estimativa da confiabilidade das escalas IDATE-Traço, Beck e BIS, foram calculados os coeficientes $\alpha$ de Cronbach (Nunnaly, 1978; Spector, 1992) para cada grupo de questões referentes às três escalas. Quanto maior esse coeficiente maior é a confiabilidade da escala. Na Tabela 17 são apresentadas as estimativas de confiabilidade para ambos os grupos conjuntamente e na Tabela 18 para os dois grupos separadamente.

Tabela 17: Coeficiente $\alpha$ de Cronbach e intervalos de 95\% de confiança para as escalas, calculado para os dois grupos em conjunto.

\begin{tabular}{ccc}
\hline ESCALA & $\alpha$ & Intervalo de confiança \\
\hline IDATE-T & 0.81 & {$[0,76 ; 0,87]$} \\
BECK & 0.84 & {$[0,79 ; 0,88]$} \\
BIS & 0.79 & {$[0,67 ; 0,82]$} \\
\hline
\end{tabular}

Considerando-se os dois grupos separadamente e calculando-se os respectivos coeficientes (Tabela 18) percebe-se que as escalas de depressão (0.77) e impulsividade (0.67), no grupo de usuários, apresentaram baixa confiabilidade. No entanto, ao comparar os dois grupos, nota-se que existe uma intersecção entre os intervalos de confiança e, portanto, não se pode dizer que 
nos não usuários as escalas sejam mais confiáveis, embora se verifiquem maiores coeficientes nessa amostra.

Tabela 18: Coeficiente de Confiabilidade $\alpha$ de Cronbach para as questões de cada escala calculado para os dois grupos separadamente.

\begin{tabular}{ccc|cc}
\hline \multirow{2}{*}{ ESCALA } & USUÁRIO & NÃO USUÁRIO & USUÁRIO & NÃO USUÁRIO \\
\hline IDATE-T & 0.80 & 0.82 & {$[0,70 ; 0,87]$} & {$[0,74 ; 0,88]$} \\
BECK & 0.77 & 0.85 & {$[0,65 ; 0,86]$} & {$[0,78 ; 0,90]$} \\
BIS & 0.67 & 0.81 & {$[0,50 ; 0,81]$} & {$[0,72 ; 0,88]$} \\
\hline
\end{tabular}




\section{DISCUSSÃO}

Uma vez que o uso de "êxtase" é ilegal e pouco difundido no Brasil, a preocupação inicial que norteou a elaboração do método da presente pesquisa foi atingir espaço amostral suficiente a uma análise quantitativa, obtendo respostas confiáveis. Tais preocupações estão diretamente relacionadas ao recrutamento dos sujeitos.

O recrutamento de sujeitos usuários de "êxtase” em contexto hospitalar, clínicas ou consultórios é impraticável, porque os usuários não procuram tratamento para seu abuso ou dependência. Consultas à literatura demonstraram que a técnica de amostragem snowball é a mais utilizada em pesquisas sobre o "êxtase" (Calafat et al., 1998; Curran \& Travill, 1997; Forsyth, 1996; Parrott \& Lasky, 1998; Solowij et al., 1992). A partir da experiência dessas investigações decidiu-se utilizar a técnica snowball, que teve bons resultados permitindo inclusive ser sugerida a futuras pesquisas na área.

É importante salientar que foi necessário efetuar uma modificação do planejamento metodológico inicial, em que as entrevistas eram realizadas em locais privados, escolhidos pelo sujeito. Aos entrevistados era solicitada a indicação de amigos ou conhecidos que por sua vez eram contatados por telefone e concordando em conceder entrevista, determinavam hora e local que lhes fosse apropriado. Tal procedimento verificou-se custoso e demandou muito tempo, gerando grandes intervalos entre as entrevistas. Após a realização de várias entrevistas dessa forma, alguns sujeitos sugeriram à pesquisadora que os acompanhasse a locais públicos onde estavam presentes amigos ou conhecidos seus, que preenchiam os critérios solicitados pela pesquisa, dispondo-se a apresentá-los. Uma vez que tal mudança não demonstrou prejudicar a confiabilidade das respostas, ao mesmo tempo que abreviava o custo e tempo de obtenção dos dados, variável importante em fenômenos de transformação tão rápida quanto o uso de “êxtase”, e apenas mantinha a limitação já conhecida imposta pela estratificação de amostras snowball, a adaptação da técnica pareceu produtiva e benéfica. Tal adaptação aparece refletida na desigualdade do número de entrevistados partindo de cada sujeito inicial, pois o sujeito número três indicou dois indivíduos que se propuseram a acompanhar a pesquisadora a locais públicos, o que desencadeou um grande volume de entrevistas. Se por 
um lado essa desigualdade pode determinar resultados restritos a um determinado grupo de usuários, o uso de "êxtase" é de fato restrito e por isso se supõe que os resultados se referem no mínimo a um grupo influente, quiçá majoritário, de usuários. De qualquer forma é importante salientar que embora a presente pesquisa seja de caráter quantitativo, os dados obtidos não devem ser generalizados pois é preciso se levar em conta a especificidade da amostra recrutada através da técnica snowball.

Quanto à fidedignidade das respostas, alguns fatos ocorridos durante a aplicação dos questionários sugerem confiança na pesquisadora e falta de receio da ilegalidade do uso de substâncias por parte dos sujeitos entrevistados. São eles: (a) o pequeno número de recusas, (b) a disponibilidade dos sujeitos em indicar amigos e conhecidos para responder ao questionário, (c) a alta frequência de depoimentos sobre uso de drogas ilegais após a entrevista e de solicitações de informações sobre as consequências do uso, (d) as frequentes sugestões de que a pesquisadora experimentasse a droga se dispondo a fornecê-la a preço de custo e de boa qualidade, (e) a solicitação de auxílio de um sujeito para responder à pergunta “De quem você compra "êxtase"?”, pois este traficava "êxtase”. Tais episódios demonstram a tranquilidade dos usuários em relação ao seu consumo e ausência de motivos para encobrir o uso, sugerindo a veracidade das respostas obtidas.

Embora apenas os dados de usuários classificados como habituais tenham sido analisados, vale interpretar a incidência de outros padrões de uso na amostra total de usuários. Esses números, na falta de dados epidemiológicos mais consistentes, indicam tendências e parecem confirmar a suposição de que o uso de “êxtase” seja um fenômeno em ascensão em São Paulo. O grande número de usuários experimentais e a pequena quantidade de ex-usuários poderiam ser interpretados como expressão de um início da popularização do "êxtase" em São Paulo. Uma vez que o uso de "êxtase" existe há relativamente pouco tempo no Brasil (provavelmente há no máximo cinco anos da realização das entrevistas), ainda não há tempo suficiente para que um grande número de pessoas sejam ex-usuárias, e por outro lado muitos ainda estão na fase de experimentação. É digno de nota que diversos usuários experimentais disseram ter utilizado a droga três vezes ou menos, enfatizando "por enquanto..." e manifestando seu desejo de utilizar novamente. A pequena porcentagem de usuários esporádicos também pode refletir um padrão de uso constatado em trabalho sobre consumo de maconha como uma 
curva ascendente que se estabiliza e decresce, quando então se torna mais esporádico (Silva et al., 1989). Aqui então poderia ser necessário ainda o decurso de um certo tempo de uso até se atingir esse padrão esporádico. Quanto à tipologia "outros usuários", os padrões atípicos apareceram como mudanças bruscas na frequência de uso relacionados a circunstâncias de vida do sujeito, como por exemplo trabalho e parceiro(a). Por fim é importante frisar que a predominância de usuários habituais não pode ser considerada uma expressão de que a maioria dos usuários tenha esse padrão de uso, pois ela pode ter sido determinada pela tendência dos entrevistados em indicar para entrevista amigos de uso habitual; foram frequentes apresentações para entrevistas com o adjunto: "Esta pessoa você precisa entrevistar!". De qualquer forma não houve grande dificuldade em encontrá-los, o que supõe a facilidade de se adquirir comprimidos de "êxtase" em São Paulo.

No que se refere às características sócio-demográficas da amostra, a maior parte foi composta de indivíduos jovens, heterossexuais, solteiros, de nível superior e de classe média. Os dois grupos de sujeitos, usuários e grupo controle de não usuários, apresentaram perfis bastante semelhantes entre si e em alguns casos, peculiares em relação à população em geral. Considerando a porcentagem de homens e mulheres, embora a diferença entre os dois grupos não seja significativa, verifica-se que no grupo de não usuários ela é muito semelhante, enquanto no grupo de usuários a porcentagem de homens é maior que a de mulheres. Isso poderia sugerir que em um grupo de pessoas com valores, hábitos e condições sócioeconômicas semelhantes, os homens estão mais propensos a utilizar "êxtase", observação que segue a tendência apontada em numerosos estudos sobre drogas que constatam um maior índice de homens entre os usuários de drogas psicotrópicas ilegais (Carlini et al., 1990; Carlini-Cotrim et al., 1989; Galduróz et al., 1994; Galduróz et al., 1997).

Quanto à opção sexual, não houve diferenças significativas entre os dois grupos, embora a quantidade de sujeitos cuja opção sexual foi homo ou bissexual tenha sido maior entre usuários (33,3\%) do que entre não usuários (22\%). A porcentagem de homo ou bissexuais na população é um assunto polêmico e não há dados brasileiros confiáveis. Pesquisa realizada nos Estados Unidos obteve que apenas 1,4\% das mulheres e 2,8\% dos homens afirmaram ser homo ou bissexuais quando perguntado qual era sua opção sexual, tal qual na presente pesquisa (Michael, Gagnon, Laumann \& Kolata, 1994). Dessa forma entre a população 
entrevistada a porcentagem de homo e bissexuais é bastante superior ao esperado na população em geral. Esse dado pode estar relacionado a uma postura liberal em relação à sexualidade, marcadamente presente em culturas jovens de vanguarda e em especial na cultura clubber. Embora a literatura não confirme (Buffum \& Moser, 1986), um dos efeitos atribuídos ao "êxtase" é um aumento do desejo sexual, expectativa que por si só pode causar um efeito placebo, de fato o aumentando. Em um ambiente sem preconceitos isso poderia estimular novas experiências sexuais. Há ainda o fato de que o uso de "êxtase" aparece inicialmente em São Paulo em clubes noturnos, locais muito frequentados pela comunidade gay.

Os sujeitos são predominantemente solteiros, que é de fato o que se espera para a idade média dos entrevistados. A escolaridade é muito semelhante nos dois grupos e indica uma população de classe sócio-econômica média a alta, em que quase $60 \%$ são universitários e 34\% têm colegial completo ou incompleto. De fato, mais de $75 \%$ dos sujeitos entrevistados se atribuem classe alta, média alta ou média. Porém, os dois grupos apresentam diferenças significativas em dois tipos de ocupação: não usuários são mais frequentemente estudantes, enquanto usuários têm mais frequentemente ocupação como “freelancer/bicos”. Embora a variável idade não tenha apresentado diferença estatisticamente significativa, a idade mediana dos usuários é de 23 anos e a dos não usuários é de 20 anos. Como foi visto, dividindo-se os sujeitos nas faixas etárias definidas pela OMS verificamos uma forte tendência de não usuários serem mais jovens do que usuários. Portanto é importante sublinhar que, embora a diferença de idade seja pequena e não significativa, ela se dá justamente em uma faixa etária em que indivíduos de classe sócio-econômica média a alta ainda estão cursando a universidade ou iniciando sua vida profissional. Assim, a diferença ocupacional diagnosticada poderia ser consequência da pequena mas determinante diferença de idade, quando não usuários ainda não trabalham por estarem estudando e usuários estão iniciando sua entrada no mercado de trabalho como freelancers ou fazendo bicos. Uma outra hipótese para o trabalho como "freelancers/bicos" ser significativamente superior entre os usuários seria de que eles trabalham esporadicamente em raves, dada sua alta frequência a elas.

Quanto à religião, não usuários afirmam mais frequentemente ter religião, diferença que foi estatisticamente significativa. Pesquisa sobre “êxtase” realizada na Europa, em cidades de 
cinco países diferentes, mostrou que embora haja variações de um país para outro no que se refere a acreditar em uma religião, refletindo as diferenças de padrões culturais entre eles, em todas as cidades os consumidores de "êxtase” acreditavam com menos frequência em alguma religião do que não usuários, o que portanto também foi constatado na presente amostra (Calafat et al., 1998). Entretanto, nota-se que enquanto "ter religião" apresentou diferenças significativas entre os dois grupos, a "importância da religião" para o indivíduo não as apresentou. Assim, talvez não se possa concluir que a religião seja de fato um fator protetor ao uso de "êxtase". Essas diferenças poderiam estar relacionadas mais uma vez à diferença etária entre os dois grupos, onde os não usuários por serem mais jovens ainda estariam mais ligados aos valores familiares.

Vários pesquisadores apontam o relacionamento familiar como um fator importante no uso de drogas (Bucher, 1989; Hawkins, Lishner, \& Catalano, 1985). Na presente pesquisa essa não foi uma variável que diferenciou significativamente os dois grupos, ainda que apenas no grupo de usuários tenha sido assinalada a alternativa relacionamento com os pais "ruim ou muito ruim”. Uma vez que 69,3 \% da amostra total pesquisada é composta por adolescentes e jovens adultos, faixas etárias notoriamente vinculadas a dificuldades de relacionamento com os pais, parece surpreendente o fato de que a grande maioria dos entrevistados nos dois grupos julgue o relacionamento com seus pais "bom ou muito bom" e que apenas 2,8\% dos sujeitos entrevistados tenham apontado o relacionamento com os pais como "ruim ou muito ruim”. A já citada pesquisa realizada na Europa encontrou resultados semelhantes (Calafat et al., 1998). Esses dados indicam que a amostra total pesquisada, ou seja: "indivíduos que frequentam uma atmosfera onde o uso de "êxtase” é estranho ou incomum", se constitui de uma população cujas relações familiares são aparentemente satisfatórias, o que não é característica de uma população marginal.

Já as variáveis renda e gasto semanal "para sair" parecem estar diretamente relacionadas, sendo significativas as diferenças entre os grupos: usuários apresentaram ambas superiores a não usuários. Essas variáveis estão estreitamente relacionadas à ocupação, e uma vez que o grupo de não usuários é composto mais frequentemente de estudantes, é provável que tenham menor renda mensal e por conseguinte menor disponibilidade de gasto com lazer. Também 
pode-se supor que o maior gasto semanal esteja relacionado ao uso de "êxtase", que custa por volta de R\$ 30,00, e à frequência superior dos usuários a "lugares para dançar” e raves.

Outras diferenças estatisticamente significativas entre os dois grupos foram o uso de piercings e tatuagens, que podem ser descritos como símbolos que representam uma marca de identidade social e individual. Os usuários portam quantidade consideravelmente maior de ambos, aspecto que está relacionado à cultura dessa população, seus valores e padrões de beleza. É curioso relatar que muitos dos entrevistados de ambos os grupos disseram que não tinham tatuagens ou piercings "ainda", mas que pretendiam fazê-los brevemente. Isso parece indicar a forte valorização de tais marcas nesse grupo de indivíduos e demonstra a importância em identificar-se com o grupo e diferenciar-se dos demais. A preferência pela música techno também foi expressivamente superior entre os usuários de "êxtase". Pesquisa realizada na Escócia concluiu que entre adolescentes que preferiam rave music (variados tipos de música eletrônica) havia mais indivíduos que já haviam utilizado "êxtase" quando comparados a adolescentes com outras preferências musicais (Forsyth, Barnard, \& McKeganey, 1997). Essa relação poderia ser explicada tanto pelo efeito do "êxtase” que despertaria a sensibilidade para esse tipo de música em especial, como também por uma possível etiologia comum, o que parece mais plausível. Ambos são elementos uma cultura jovem específica com seus valores, códigos, modismos, preferência musical e tipo de droga particulares.

Com relação aos locais mais frequentados pelos dois grupos a única diferença estatisticamente significativa entre eles é com relação à frequência a raves, o que relaciona esse tipo de festa ao uso de "êxtase”. Não foi investigada a frequência a after-hours (em português depois da hora: lugares para dançar após as cinco horas da manhã, que surgem por volta de 1995 em São Paulo), que provavelmente também apresentaria diferenças significativas entre os dois grupos. Mais uma vez essas diferenças definem um estilo de vida aqui associando o lazer ao uso de "êxtase”.

Uma das diferenças marcantes entre os dois grupos diz respeito ao consumo de drogas psicotrópicas. A porcentagem de usuários que utilizaram pelo menos uma vez na vida determinada droga é superior para todas as drogas pesquisadas, incluindo as legalizadas. A 
única diferença não significativa entre os dois grupos é quanto ao álcool, embora também uma maior porcentagem de usuários já o tenham utilizado na vida. São dignos de nota os seguintes resultados: (a) a porcentagem de usuários que já experimentou opiáceos (morfina, heroína, ópio), drogas raras no Brasil, é muito alta (35\%), suplantando o crack, tão mais barato e comum; (b) o LSD foi utilizado pelo menos uma vez na vida por todos os usuários entrevistados, resultado que o coloca, ao lado da maconha, como a droga mais experimentada por esse grupo, com índices de uso surpreendentemente superiores ao álcool e ao tabaco; (c) os usuários experimentaram muitas outras drogas além das que estavam relacionadas no questionário; dentre elas, as que apareceram mais frequentemente foram: mescalina (alucinógeno, princípio ativo do peyote), speed (estimulantes variados), poppers (solvente volátil à base de nitrito), charras e skank (produtos da Cannabis Sativa mais potentes do que a maconha).

A frequência de uso no último mês também é superior no grupo usuários para todas as drogas pesquisadas, exceto para o álcool que foi mais utilizado pelos não usuários, embora essa diferença não tenha sido significativa. Novamente é digno de nota que $7 \%$ dos usuários tenham usado opiáceos no último mês. Ressalta-se ainda que mais de 50\% dos usuários utilizaram LSD, o que parece demonstrar uma preferência desse grupo por essa droga, considerando que a cocaína, droga disponível e acessível em São Paulo, foi utilizada por apenas 35\% deles. A maconha foi porcentualmente mais utilizada do que o álcool e o tabaco pelos usuários no último mês, resultado inverso ao obtido no grupo de não usuários.

Ao comparar os quatro levantamentos brasileiros sobre o uso de drogas por estudantes de escolas públicas verifica-se que as drogas mais consumidas mantiveram suas posições ao longo de oito anos que decorreram entre o primeiro e o último levantamento. Em ordem decrescente são elas: (1) álcool, (2) tabaco, (3) solventes, (4) ansiolíticos, e (5)(6) anfetamina ou maconha, que alternaram posições conforme a cidade. Na população pesquisada a ordem de utilização na vida na amostra global é a seguinte: (1) álcool, (2) maconha, (3) tabaco, (4) solventes, (5) LSD, (6) cocaína, (7) anfetamina, (8) chás, (9) tranquilizantes. Observa-se que na população pesquisada a porcentagem de sujeitos que já experimentou drogas legais ou ilegais é muito superior à população de estudantes, mas é preciso notar que se trata de uma população diferente, de faixa etária mais alta e proveniente de classe sócio-econômica mais 
elevada. De qualquer forma pode-se supor que a droga mais utilizada não se justifica exclusivamente por sua disponibilidade, pois drogas legais, mesmo que controladas, não são de difícil obtenção para uma classe de poder aquisitivo superior à dos estudantes de escolas públicas. Esse fato é importante, pois sugere que a escolha da droga a ser utilizada pela população pesquisada não é apenas função de sua disponibilidade. Parece mais plausível supor que a eleição da droga seja determinada pelo efeito que ela provoca.

Na Europa, considerando-se a amostra global constituída por população frequentadora de clubes noturnos, as drogas mais utilizadas durante o último mês foram: (1) álcool, (2) tabaco, (3) maconha, (4) cocaína, (5) anfetamina, (6) LSD (Calafat et al., 1998). Comparando o tipo de droga utilizada por essas três populações nota-se que, embora cada uma tenha suas particularidades, a amostra pesquisada situa-se entre a população européia e a dos estudantes brasileiros.

Segundo a OMS (1980), o indivíduo mais propenso a usar drogas é aquele que: (1) não tem informações adequadas sobre o efeito das drogas, (2) tem saúde deficiente, (3) está insatisfeito com sua qualidade de vida, (4) tem personalidade deficientemente integrada e (5) têm fácil acesso às drogas (Galduróz et al., 1997). No caso da presente pesquisa, a amostra não parece se enquadrar nas quatro primeiras características supra citadas, pois os sujeitos têm escolaridade e condições econômicas acima da média da população em geral, estudam ou trabalham, têm atividades de lazer e amigos, além de relações familiares satisfatórias. O quinto aspecto parece portanto preponderar: acesso facilitado às drogas. De fato se observa que, diante da indagação sobre a quantidade de amigos usuários de ”êxtase”, aparece uma diferença significativamente superior de amigos usuários entre os usuários, como seria esperado. É plausível supor que o mesmo aconteceria se a pergunta fosse sobre a quantidade de amigos que utilizam outras drogas.

Além do acesso facilitado às drogas, que faria com que os usuários tivessem mais oportunidades de uso, é provável que eles tenham presenciado mais vezes o uso de drogas por amigos, e tenham menos medo de experimentá-las e menos preconceito em relação a elas. Assim, oportunidades mais frequentes, menos medo e preconceito com relação às drogas seriam variáveis interdependentes predisponentes ao uso de drogas, inclusive "êxtase”. As 
posições de consumo não são as mesmas entre uso na vida e no mês para os usuários, indicando novamente uma seletividade no consumo, não relacionada com a disponibilidade da droga mas mais provavelmente relacionada à valorização da droga pelo grupo e ao efeito que provoca.

Em relação à pergunta "Você acha que tomar êxtase pode trazer problemas para quem usa?", não se previa a semelhança na quantidade de problemas apontados pelos dois grupos, e observa-se que a grande maioria dos entrevistados de ambos os grupos acredita que o uso de “êxtase” possa trazer problemas. Na Europa também foi observado que a maioria da população entrevistada acreditava que seu uso podia trazer problemas, mas a diferença entre usuários e não usuários europeus é significativa, mais usuários acreditam que o uso de “êxtase” não traz nenhum problema (Calafat et al., 1998). Na presente pesquisa apenas a ordem dos problemas é distinta nos dois grupos: a maior preocupação dos usuários é a adulteração do comprimido enquanto que os não usuários estão mais preocupados com malefícios à saúde e problemas psicológicos advindos do uso de "êxtase”.

De fato parece que a população entrevistada acredita que não seja bom usar drogas, já que a grande maioria declara pensar ou já ter pensado em parar de usar alguma droga. Esse é um dado interessante para elaboração de projetos preventivos, ou seja, parece que apenas o conhecimento dos malefícios causados pelo uso de drogas não é suficiente para evitar o consumo e que simplesmente desejar não usar não basta para conseguí-lo, como podemos comprovar pela quantidade de fumantes, dependentes de nicotina que têm muita dificuldade de parar de fumar.

\section{Padrões de uso}

Segundo Palomino, as primeiras remessas de comprimidos de "êxtase" chegaram a São Paulo em 1994 (Palomino, 1999). Como as entrevistas foram realizadas entre maio e julho de 1999, o tempo de uso da maioria dos entrevistados entre dois e quatro anos está de acordo com essa informação. Ainda segundo essa autora, nessa época não havia "traficantes”, ou seja, pessoas que se ocupam da venda de “êxtase”. Alguns indivíduos traziam do exterior alguns comprimidos e os revendiam seletivamente a amigos clubbers. Assim, os 28\% dos usuários 
que usaram "êxtase” pela primeira vez há mais de cinco anos provavelmente o fizeram fora do Brasil ou esporadicamente, conseguindo o comprimido através de amigos que traziam pequenas quantidades.

Quanto à idade, mais da metade dos usuários experimentaram "êxtase” na adolescência, segundo as faixas etárias definidas pela OMS. Esse dado é similar ao encontrado na Europa e determina que projetos de prevenção ao uso de "êxtase" devem ser direcionados a esse público.

Em relação à frequência de uso de "êxtase”, além da estabilidade do uso comparando-se o último aos três últimos meses, observa-se que mais de $20 \%$ dos usuários entrevistados usa “êxtase” mais de uma vez por semana, o que os enquadraria na categoria de "usuário compulsivo”, de acordo com a classificação utilizada por Calafat. Na Europa a cidade onde se obteve maior índice de usuários compulsivos foi Nice (França), com 13,4\% dos usuários entrevistados. Já em Sidney apenas 4,9\% dos usuários usam “êxtase” mais de uma vez por semana (Solowij et al., 1992). Nota-se que a prevalência de "usuários compulsivos” na amostra da presente pesquisa é bastante superior a das amostras européias e australiana. Uma explicação possível seria a já citada tendência dos entrevistados de indicar amigos de uso frequente, outra hipótese seria que esse dado reflete a tendência ascendente do consumo inicial, também já colocada.

Os padrões circunstanciais de uso de "êxtase” dos usuários entrevistados são semelhantes aos descritos pelas pesquisas realizadas na Europa e em Sidney: a maioria dos usuários toma um ou dois comprimidos a cada episódio de uso, apenas nos finais de semana ou férias, mais frequentemente na companhia de várias pessoas, particularmente em ambientes ligados ao lazer noturno como lugares para dançar, raves e festas. Os comprimidos são comprados mais frequentemente de amigos em raves, festas, "lugares para dançar" ou bares. Esses padrões de aquisição e consumo indicam o caráter pouco marginal do uso, em especial se comparados aos padrões mais comuns de aquisição e local de consumo de crack, para tomar um exemplo. Tais padrões estão de acordo com as principais razões apontadas para se usar "êxtase”, que são: dançar, relaxar, estimular os sentidos, sentir-se mais feliz, sentir-se melhor com os outros. Pode-se observar que apenas em sexto lugar aparece uma razão que diz respeito a um 
mal estar psíquico: “fugir da realidade ou esquecer problemas”. Ainda é muito interessante notar que menos de um quinto dos entrevistados apontam "transar" como uma razão para o uso, embora seja difundido que o “êxtase”, até pelo próprio nome, é uma droga afrodisíaca.

Ainda com relação aos padrões de uso, é preocupante do ponto de vista físico, a frequência de uso de outras drogas enquanto o "êxtase” está fazendo efeito, pois obviamente a combinação de psicotrópicos aumenta o risco de intoxicação. Apenas uma minoria $(7,7 \%)$ não o associa a outras drogas psicotrópicas. A droga mais frequentemente associada ao "êxtase” é a maconha, sendo também utilizados: tabaco, LSD, álcool, e cocaína ou crack, nesta ordem. Também na Europa os usuários frequentemente fazem associações de "êxtase” e outras drogas, embora em ordem distinta e variável conforme a cidade, lá as drogas mais associadas ao “êxtase” são: tabaco, maconha, álcool, cocaína, LSD e anfetamina. Nota-se que na amostra européia é mais comum a associação de "êxtase” e álcool do que no Brasil. Na presente pesquisa chama a atenção o fato de mais indivíduos associarem "êxtase” à maconha e/ou ao LSD do que ao álcool, indicando uma preferência pela somatória de efeitos de drogas perturbadoras (alucinógenas para alguns autores) ao efeito do "êxtase”.

Uma vez que a amostra analisada era constituída exclusivamente por usuários habituais, era esperado que nenhum deles assinalasse que os efeitos do "êxtase” eram na maior parte das vezes "negativos", o que de fato aconteceu. Aproximadamente um terço deles considera os efeitos na maior parte das vezes "positivos e negativos" e a maioria os considera "positivos". Na Europa os resultados foram semelhantes, embora em algumas cidades uma porcentagem de usuários de “êxtase” tenham considerado os efeitos na maior parte das vezes “negativos”. Provavelmente essa diferença é reflexo da diferença amostral que na Europa incluiu usuários experimentais e ex-usuários. Observa-se que há uma congruência entre os efeitos mais frequentemente assinalados pelos usuários que julgam os efeitos "positivos e negativos" e os que os julgam apenas "positivos”. Para esses últimos, os efeitos mais assinalados são exclusivamente prazerosos, enquanto que os outros assinalam além de efeitos prazerosos alguns desagradáveis como "boca seca", "taquicardia" e "ondas de frio e calor". Futuras pesquisas poderiam incluir investigação sobre os efeitos posteriores ao uso de "êxtase", o que não foi investigado na presente pesquisa. É digno de nota que de forma geral os efeitos sejam tão agradáveis, fato que deve ser levado em conta no planejamento de ações preventivas ao 
abuso de "êxtase”. Ao comparar com os resultados obtidos em pesquisa realizada em Sidney observa-se que há diferenças e semelhanças nos efeitos mais frequentemente assinalados, como pode ser observado na Tabela abaixo:

Tabela 19. Dez efeitos mais frequentemente assinalados pelas amostras

\begin{tabular}{ll}
\hline Amostra total de usuários de São Paulo & \multicolumn{1}{c}{ Amostra Sidney } \\
\hline Feliz & $\underline{\text { Falante }}$ \\
$\underline{\text { Amorosa(o) }}$ & Mente aberta \\
$\underline{\text { Com energia }}$ & Mais próximo dos outros \\
Mais próximo dos outros & Feliz \\
À vontade & À vontade \\
$\underline{\text { Em paz }}$ & $\underline{\text { Aberto ao ambiente }}$ \\
$\underline{\text { Com tesão }}$ & $\underline{\text { Sensual }}$ \\
Mente aberta & $\underline{\text { Eufórico }}$ \\
Despreocupado & $\underline{\text { Auto confiante }}$ \\
Calmo & Despreocupado \\
\hline
\end{tabular}

OBS: Efeitos sublinhados se referem às diferenças

Uma vez que o questionário aplicado em São Paulo incluiu uma lista de efeitos traduzida do questionário utilizado em Sidney, três hipóteses poderiam explicar as diferenças dos resultados obtidos nas duas amostras: a primeira seria que a composição dos comprimidos pode não ser a mesma, a segunda é que haja diferenças com relação à expectativa de efeito do “êxtase” nos dois países, fator que pode modular os efeitos de drogas psicotrópicas, e a terceira diz respeito a problemas de tradução, pois embora tenha se procurado ser o mais fiel possível à relação original utilizando um vocabulário cotidiano, isso pode não ter sido possível com algumas expressões como por exemplo insights, que permaneceu em inglês com aspas. De qualquer forma as semelhanças parecem indicar tratar-se no mínimo de uma droga semelhante, e indutora de efeitos positivos.

\section{Escalas Psicológicas}


Em relação às escalas psicológicas os resultados da confiabilidade, calculados através dos coeficientes $\alpha$ de Cronbach, constatam que as três podem ser consideradas confiáveis para ambos os grupos, além de apresentarem coeficientes semelhantes.

Na escala de Depressão de Beck a média da pontuação obtida pelos não usuários foi significativamente superior a dos usuários. Esse resultado vai contra o que seria esperado, tendo em vista o efeito da droga sobre o sistema serotonérgico como mencionado na introdução, mesmo considerando que ambas as médias sejam inferiores a 16 e portanto dentro da categoria "baixa". Assim, os usuários entrevistados apresentam um humor mais elevado do que os não usuários. Segundo Beck, autor da escala aplicada, o paciente deprimido encara a si, a seu futuro e as suas experiências de forma negativista, ou seja, ele se percebe como defeituoso e inadequado, quando faz projeções prevê dificuldades e sofrimentos e interpreta sua interação com o mundo como demonstrações de fracasso. Além disso o indivíduo deprimido tem uma tendência a manter as atitudes causadoras de sofrimento e auto derrotistas (Beck, Rush, Shaw, \& Emery, 1979). Portanto, uma possível explicação para o uso de "êxtase" seria esse humor mais elevado dos usuários, que teriam maior disposição em experimentar e usar "êxtase" por anteciparem consequências positivas, como por exemplo: ter "boas viagens" com a droga, se tornar mais amoroso, com mais energia, se sentir à vontade e mais próximo das outras pessoas. Além disso, esse indivíduo teria mais facilidade em procurar experiências novas, pois interpreta suas interações com o mundo de forma positiva.

Nas outras duas escalas psicológicas utilizadas, IDATE e BIS, usuários e não usuários não apresentaram diferenças estatisticamente significativas entre si, sendo que os resultados são tão semelhantes que não indicam sequer tendências. De forma geral pode-se concluir que tanto usuários quanto não usuários não apresentam sintomas depressivos, impulsivos ou ansiosos, tal como medidos por esses instrumentos.

É importante mencionar que pesquisa realizada na Inglaterra, com usuários que consumiam em média três comprimidos de "êxtase” por mês há em média mais de 2 anos, constatou nesses usuários elevado traço de impulsividade quando comparados tanto a não usuários quanto a poli-usuários de drogas. Segundo esse autor, é possível que a impulsividade elevada seja consequente à neurotoxicidade ocasionada pelo uso da MDMA, já que reduções na função serotonérgica estão associadas a aumento de comportamento impulsivo (Morgan, 
1998). Outra pesquisadora relata ter encontrado escores de impulsividade e hostilidade indireta significativamente mais baixos em amostra de 30 usuários recreativos de "êxtase”, quando comparados a um grupo controle composto de indivíduos que nunca o haviam utilizado (McCann, Ridenour, Shaham, \& Ricaurte, 1994). O que se pode dizer é que até o momento não foi comprovada nem descartada uma relação de causalidade entre uso de MDMA e impulsividade.

É importante salientar que qualquer escala auto-aplicável é um instrumento grosseiro, se comparada a um diagnóstico clínico. Isso significa que os dados obtidos através das escalas psicológicas não são conclusivos no que se refere às características dos sujeitos entrevistados, nem podem ser generalizados. Novas pesquisas utilizando diferentes instrumentos seriam úteis e necessárias para chegar a conclusões a respeito dos traços de personalidade que predispõem ou podem decorrer do uso de "êxtase”.

\section{Considerações finais}

A julgar pelos resultados obtidos o uso de "êxtase” parece de fato ser recente e crescente em São Paulo. Por um lado o usuário de “êxtase” é favorecido pelo desconhecimento e desinteresse da sociedade sobre essa nova droga pois resulta em mínimo risco legal do consumo. Por outro lado esse desconhecimento pode ser um problema para usuários que tenham que recorrer a intervenções médicas em função de complicações clínicas agudas decorrentes do uso de "êxtase”. Além disso, ainda há lacunas sobre o mecanismo de ação da MDMA, sobre a interação da MDMA com outras substâncias, sobre os motivos das diferenças nas reações individuais à droga e sobre as consequências do uso a longo prazo. Também é importante destacar que a ilegalidade é um fator que torna incerta e não fiscalizada a composição do comprimido (diga-se de passagem que há páginas na Internet que divulgam como sintetizar MDMA). Sínteses caseiras, sem a tecnologia adequada, podem levar a substâncias de consequências neurológicas perigosas e por vezes irreversíveis. Assim, a escolha individual de usar "êxtase” comporta sempre, até o momento, um certo risco, e nesse sentido é justificada uma intervenção preventiva com relação ao uso de “êxtase”, que para ser efetiva deve levar em conta as características da população consumidora e também deve ter como objetivo capacitar profissionais de saúde para intervenções médicas de emergência em 
casos de intoxicação. Além disso seria valiosa uma análise química dos comprimidos mais utilizados nas cidades em que o uso existe. Vale a observação de que na Holanda alguns clubes noturnos realizam gratuitamente exames dos comprimidos de quem se dispõe a fornecê-los, devolvendo o comprido e informando o consumidor sobre sua composição.

Se atentarmos às condições sociais, ao estilo de vida, às principais razões do uso de "êxtase" e aos efeitos mais frequentemente relatados pelos usuários entrevistados, é plausível supor que ao utilizar “êxtase” esses indivíduos não têm como objetivo fugir de uma realidade insatisfatória, punitiva ou frustradora. Parece que o uso de “êxtase” é simplesmente uma busca hedonista, uma possibilidade de intensificar o prazer de ouvir música e dançar na companhia de amigos, uma vontade de se divertir o máximo possível durante o final de semana. É possível que essa busca de prazer acabe ocasionando desprazer em alguns casos, geralmente em usuários compulsivos, podendo gerar problemas físicos e/ou emocionais. Poderia ainda se especular sobre o quanto o uso de "êxtase" interferiria no amadurecimento psico-social do usuário. Mas para um público adolescente ou jovem adulto que vive uma realidade confortável e divertida tais possibilidades não preocupam muito. Talvez para esse público a principal desvantagem que o uso de "êxtase" traz seria uma alteração de humor posterior ao uso relatada por alguns pesquisadores (Curran \& Travill, 1997; Parrott \& Lasky, 1998).

Seria muito interessante se a amostra de não usuários pudesse ser novamente entrevistada passado um ano da entrevista realizada. Dadas as semelhanças sócio demográficas e culturais expressas pelos valores comuns e pelo acesso facilitado ao "êxtase”, é plausível supor que muitos dos não usuários tenham experimentado a droga neste intervalo. Entretanto é impossível comprovar essa suposição. Também seria interessante verificar, caso o "êxtase" se popularize, se os padrões de uso, as motivações para o uso e até os efeitos a ele atribuídos se mantêm.

A análise dos resultados da presente pesquisa sugere que intervenções preventivas de caráter primário e secundário seriam adequadas e necessárias. A intervenção preventiva primária objetiva impedir que dado indivíduo experimente a droga. Em geral programas desse tipo têm eficiência limitada e encerram-se no momento que o sujeito experimenta a droga em questão. 
A intervenção secundária é direcionada a indivíduos que já utilizaram a droga e tem como objetivo impedir que o indivíduo continue a usá-la inibindo o abuso e a dependência. No caso do uso de “êxtase” essa estratégia também seria útil porém tem suas limitações, ainda mais quando se trata de uma droga com efeitos descritos como tão prazerosos. Outro tipo de intervenção, que inclusive não exclui as outras, seria a Redução de Dano, em que uma vez que o indivíduo já utiliza determinada droga são fornecidas informações para que, se ele não puder, não quiser ou não conseguir deixar de consumi-la, que o faça com menores riscos.

Assim, estratégias preventivas ao uso de “êxtase” devem levar em conta a população específica a qual se destina e ter em mente que a Redução de Dano é a estratégia preventiva atualmente mais utilizada na Europa, onde seu consumo é muito disseminado. A maioria dos clubes noturnos europeus adaptaram-se visando proporcionar maior segurança aos usuários, criando “Chill ins”, (salas com música mais baixa, lugares para sentar e ventilação) e fornecendo água gratuitamente aos frequentadores.

Qualquer que seja a opção preventiva, é preciso ter claro que sempre haverá indivíduos que irão optar por experimentar "êxtase”, dos quais alguns passarão a usá-lo com alguma frequência. A proibição, a punição e a discriminação nunca foram efetivas para o desencorajamento daqueles que escolhem usar determinada droga, o que pode ser evidenciado através de exemplos históricos como a Lei Seca. Assim, de acordo com a estratégia de Redução de Dano é importante a divulgação de informações de segurança para aqueles que utilizam ou venham a utilizar “êxtase”. Tais informações encontram-se no anexo C. 


\section{REFERÊNCIAS BIBLIOGRAFICAS}

Allen, R. P., McCann, U. D., \& Ricaurte, G. A. (1993). Persistent effects of (+/- )3,4methylenedioxymethamphetamine (MDMA, "ecstasy") on human sleep. Sleep, 16, 5604.

Bailly, D. (1999). Troubles neuropsychiatriques liés à la MDMA ("ecstasy"). L'Encéphale, $X X V, 595-602$.

Baleeiro, M. C., Siqueira, M. J., Cavalcanti, R. C., \& Sousa, V. (1999). Sexualidade do adolescente: fundamentos para uma ação educativa. Salvador: Fundação Oderbrecht.

Beck, A. T., Rush, A. J., Shaw, B. F., \& Emery, G. (1979). Terapia cognitiva da depressão (Vera Ribeiro, Trans.). Rio de Janeiro: Zahar Editores.

Beck, J., \& Morgan, P. A. (1986). Designer drug confusion: a focus on MDMA. Journal of Drug Education, 16, 287-302.

Box, S. A., Prescott, L. F., \& Freestone, S. (1997). Hyponatraemia at a rave. Postgraduate Medical Journal, 73, 53-4.

Brown, E. R., Jarvie, D. R., \& Simpson, D. (1995). Use of drugs at 'raves'. Scottish Medical Journal, 40, 168-71.

Bryden, A. A., Rothwell, P. J., \& PH, O. R. (1995). Urinary retention with misuse of "ecstasy". British Medical Journal, 310, 504.

Bucher, R., org. (1989). Prevenção ao uso indevido de drogas. (Vol. 1). Brasília: Editora Universidade de Brasília.

Buffum, J., \& Moser, C. (1986). MDMA and human sexual function. Journal of Psychoactive Drugs, 18, 355-9.

Calafat, A., Stocco, P., Mendes, F., Simon, J., Wijngaart, G., Sureda, M. P., Palmer, A., N., M., \& Zavatti, P. (1998). Characteristics and social representation of ecstasy in Europe. Valencia: Martin impressores, S.L.

Carlini, E. A., Carlini-Cotrim, B., Silva-Filho, A. R., \& Barbosa, M. T. S. (1990). II Levantamento nacional sobre o uso de psicotrópicos em estudantes de 1 o e 20 graus 1989 : Centro brasileiro de informações sobre drogas - Departamento de Psicobiologia da Escola Paulista de Medicina.

Carlini-Cotrim, B., Carlini, E. A., Silva-Filho, A. R., \& Barbosa, M. T. S. (1989). O uso de drogas psicotrópicas por estudantes de 10 e 20 graus da rede estadual em dez capitais brasileiras, em 1987 (série C: Estudos e Projetos 5): Centro de Documentação do Ministério da Saúde. 
Cesarotto, O. (1989). Escritos de Freud sobre a cocaína - um affair freudiano. São Paulo S.P.: Iluminuras.

Cloud, J. (2000, june 5). The Lure of ecstasy. Time, 155, 30-36.

Cohen, R. S. (1995). Subjective reports on the effects of the MDMA ('ecstasy') experience in humans. Progress in Neuro-Psychopharmacology \& Biological Psychiatry, 19, 113745.

Cohen, R. S. (1996). Adverse symptomatology and suicide associated with the use of methylenedioxymethamphetamine (MDMA; "Ecstasy"). Biological Psychiatry, 39, 81920.

Cook, A. (1995). Ecstasy (MDMA): alerting users to the dangers. Nursing Times, 91, 32-3.

Creighton, F. J., Black, D. L., \& Hyde, C. E. (1991). 'Ecstasy" Psychosis and Flashbacks. British Journal of Psychiatry, 159, 713-715.

Cuomo, M. J., Dyment, P. G., \& Gammino, V. M. (1994). Increasing use of "Ecstasy" (MDMA) and other hallucinogens on a college campus. Journal of American College Health, 42, 271-4.

Curran, H. V., \& Travill, R. A. (1997). Mood and cognitive effects of +/-3,4methylenedioxymethamphetamine (MDMA, 'ecstasy'): week-end 'high' followed by mid-week low. Addiction, 92, 821-31.

Elk, C. (1996). MDMA (Ecstacy): useful information for health professionals involved in drug education programs. Journal of Drug Education, 26, 349-56.

Ferigolo, M., Medeiros, F. B., \& Barros, H. M. (1998). Ecstasy: a pharmacological review. Revista de Saude Publica, 32, 487-95.

Finechi, V., Centini, F., Mazzeo, E., \& Turillazzi, E. (1999). Adam (MDMA) and Eve (MDEA) misuse: an immunohistochemical study on three fatal cases. Forensic Science International, 104, 65-74.

Forsyth, A. J. (1996). Places and patterns of drug use in the Scottish dance scene. Addiction, 91, 511-21.

Forsyth, A. J., Barnard, M., \& McKeganey, N. P. (1997). Musical preference as an indicator of adolescent drug use. Addiction, 92, 1317-25.

Galduróz, J. C. F., D'Almeida, V., Carvalho, V., \& Carlini, E. A. (1994). III Levantamento sobre o uso de drogas entre estudantes de 10 e 20 graus em dez capitais brasileiras 1993 : Centro brasileiro de informações sobre drogas - Departamento de Psicobiologia da Escola Paulista de Medicina.

Galduróz, J. C. F., Noto, A. R., \& Carlini, E. A. (1997). IV Levantamento sobre o uso de drogas entre estudantes de 1 o e 20 graus em dez capitais brasileiras - 1997 : Centro 
brasileiro de informações sobre drogas - Departamento de Psicobiologia da Escola Paulista de Medicina.

Gazzara, R. A. (1989). Inhibition of dopamine release by methylenedioxymethamphetamine is Medical Journal mediated by serotonin. European Journal Pharmocology, 168,209-17.

Goodman, L. A. (1961). Snowball sampling. Annals of Mathematical Statistics, 32, 148-170.

Gore, S. M. (1999). Fatal uncertainty: death-rate from use of ecstasy or heroin. Lancet, 354, 1265-6.

Gorenstein, C., \& Andrade, L. (1998). Inventário de depressão de Beck: propriedades psicométricas da versão em português. Revista de Psiquiatria Clínica, 25, 245-250.

Gorenstein, C., Pompéia, S., \& Andrade, L. (1995). Scores of brasilian university students on the Beck Depression and the State-Trait anxiety Inventories. Psychological Reports, 77, 635-641.

Graeff, F. G. (1989). Drogas psicotrópicas e seu modo de ação. (2 ed. rev. e ampl. ed.). São Paulo: EPU.

Green, A. R., Cross, A. J., \& Goodwin, G. M. (1995). Review of the pharmacology and clinical pharmacology of 3,4-methylenedioxymethamphetamine (MDMA or "Ecstasy"). Psychopharmacology, 119, 247-60.

Grinspoon, L., \& Bakalar, J. B. (1986). Can drugs be used to enhance the psychotherapeutic process? American Journal of Psychotherapy, 40, 393-404.

Grob, C. S., Poland, R. E., Chang, L., \& Ernst, T. (1996). Psychobiologic effects of 3,4methylenedioxymethamphetamine in humans: methodological considerations and preliminary observations. Behavioural Brain Research, 73, 103-7.

Hawkins, J. D., Lishner, D. M., \& Catalano, R. F. (1985). Childhood predictors and the prevention of adolescent substance abuse. In C. L. Jones \& R. Battjes (Eds.), Etiology of Drug Abuse (Vol. 56, ). Washington: U. S. Government Printing Office.

Holland, J. (1999). Positron emission tomography findings in heavy users of MDMA. The Lancet, 353, 592.

Huether, G., Zhou, D., \& Ruther, E. (1997). Causes and consequences of the loss of serotonergic presynapses elicited by the consumption of 3,4methylenedioxymethamphetamine (MDMA, "ecstasy") and its congeners. Journal of Neural Transmission (Budapest), 104, 771-94.

Jansen, K. L. (1999). Ecstasy (MDMA) dependence. Drug \& Alcohol Dependence, 53, 121-4.

Jansen, K. L., \& Forrest, A. R. (1999). Toxic effect of MDMA on brain serotonin neurons. Lancet, 353, 1270-1. 
Krystal, J. H., Price, L. H., Opsahl, C., Ricaurte, G. A., \& Heninger, G. R. (1992). Chronic 3,4-methylenedioxymethamphetamine (MDMA) use: effects on mood and neuropsychological function? American Journal of Drug \& Alcohol Abuse, 18, 331-41.

Lamb, R. J., \& Griffiths, R. R. (1987). Self-injection of d,1-3,4-methylenedioxymethamphetamine (MDMA) in the baboon. Psychopharmacology, 91, 268-72.

Larangeira, R., Dunn, J., Rassi, R., \& Fernandes, M. (1996). "Êxtase" (3,4 metilenodioximetanfetamina, MDMA): uma droga velha e um problema novo? Revista ABP-APAL, 18, 77-81.

Lind, J., Oyefeso, A., Polland, M., Baldacchino, A., \& Ghodse, H. (1999). Death rate from use of ecstasy or heroin. Lancet, 354, 2166-2167.

Matthai, S. M., Davidson, D. C., Sills, J. A., \& Alexandrou, D. (1996). Cerebral oedema after ingestion of MDMA ("ecstasy") and unrestricted intake of water. British Medical Journal, 312, 1359.

McCann, U. D., Mertl, M., Eligulashvili, V., \& Ricaurte, G. A. (1999). Cognitive performance in (+/-) 3,4-methylenedioxymethamphetamine (MDMA, "ecstasy") users: a controlled study. Psychopharmacology, 143, 417-25.

McCann, U. D., Ridenour, A., Shaham, Y., \& Ricaurte, G. A. (1994). Serotonin neurotoxicity after (+/-)3,4-methylenedioxymethamphetamine (MDMA; "Ecstasy"): a controlled study in humans. Neuropsychopharmacology, 10, 129-38.

McCann, U. D., Szabo, Z., Scheffel, U., Dannals, R. F., \& Ricaurte, G. A. (1998). Positron emission tomographic evidence of toxic effect of MDMA ("Ecstasy") on brain serotonin neurons in human beings. Lancet, 352, 1433-7.

McClain, H. J., \& Sapienza, F. (1989). The role of abuse liability testing in drug control procedures. In M. W. Fischman \& N. K. Mello (Eds.), Testing for abuse liability of drugs in humans (Vol. 92, pp. 21-42). Rockville.

McElhatton, P. R., Bateman, D. N., Evans, C., Pughe, K. R., \& Thomas, S. H. (1999). Congenital anomalies after prenatal ecstasy exposure. Lancet, 354, 1441-2.

McGuire, P. K., Cope, H., \& Fahy, T. A. (1994). Diversity of psychopathology associated with use of 3,4-methylenedioxymethamphetamine ('Ecstasy'). British Journal of Psychiatry, 165, 391-5.

McKenna, D. J., \& Peroutka, S. J. (1990). Neurochemistry and neurotoxicity of 3,4methylenedioxymethamphetamine (MDMA, "ecstasy"). Journal of Neurochemistry, 54, $14-22$.

Michael, R. T., Gagnon, J. H., Laumann, E. O., \& Kolata, G. (1994). Sex in America: a definitive survey. New York: Warner Books.

Milroy, C. M. (1999). Ten years of 'ecstasy'. Journal of the Royal Society of Medicine, 92, 6871. 
Morgan, J. F. (1999). Toxic effect of MDMA on brain serotonin neurons. Lancet, 353, 12689; discussion 1270-1.

Morgan, M. J. (1998). Recreational use of "ecstasy" (MDMA) is associated with elevated impulsivity. Neuropsychopharmacology, 19, 252-64.

Nardi, A. E. (1998). Comentários do debatedor: escalas de avaliação de ansiedade. Revista de Psiquiatria Clínica, 25, 331-333.

NIDA. (1998). Popular rave drug "Ecstasy" impairs memory, apparently related to brain damage : http://www.health.org/pressrel.

Nunnaly, J. C. (1978). Psychometric Theory. New York: McGraw-Hill.

O' Connor, B. (1994). Hazards associated with the recreational drug 'ecstasy'. British Journal Hosp Med, 52, 507, 510-514.

Pacifici, R., Zuccaro, P., Farré, M., Pichini, S., Di Carlo, S., Roset, P. N., Ortuño, J., Segura, J., \& De la Torre, R. (1999). Immunomodulating properties of MDMA alone and in combination with alcohol: a pilot study. Life Sciences, 65, 309-316.

Palomino, E. (1999). Babado forte: moda, música e noite na virada do século 21. São Paulo: Mandarim.

Panke, W. N., Kurland, M. D., Unger, S., Savage, C., \& Grof, S. (1970). The experimental use of psychodelic (LSD) psychotherapy. JAMA, 212, 1856-1864.

Parrott, A. C., \& Lasky, J. (1998). Ecstasy (MDMA) effects upon mood and cognition: before, during and after a Saturday night dance. Psychopharmacology, 139, 261-8.

Patton, J., Stanford, M. S., \& Barrat, E. S. (1995). Factor structure of the Barrat Impulsiveness Scale. Journal of Clinical Psychology, 51, 768-774.

Peroutka, S. J. (1987). Incidence of recreational use of 3,4methylenedimethoxymethamphetamine (MDMA, "ecstasy") on an undergraduate campus. New England Journal of Medicine, 317, 1542-3.

Rattray, M. (1991). Ecstasy: towards an understanding of the biochemical basis of the actions of MDMA. Essays in Biochemistry, 26, 77-87.

Redfearn, P. J., Agrawal, N., \& Mair, L. H. (1998). An association between the regular use of 3,4 methylenedioxy-methamphetamine (ecstasy) and excessive wear of the teeth. Addiction, 93, 745-8.

Reed, L. J., Winstock, A., Cleare, A. J., \& McGuire, P. (1999). Toxic effect of MDMA on brain serotonin neurons. Lancet, 353, 1268; discussion 1270-1.

Regenthal, R., Kruger, M., Rudolph, K., Trauer, H., \& Preiss, R. (1999). Survival after massive "ecstasy" (MDMA) ingestion. Intensive Care Medicine, 25, 640-1. 
Ricaurte, G. A., Markowska, A. L., Wenk, G. L., Hatzidimitriou, G., Wlos, J., \& Olton, D. S. (1993). 3,4-Methylenedioxymethamphetamine, Serotonin and Memory. The Journal of Pharmachology and Experimental Therapeutics, 266, 1097-1105.

Rochester, J. A., \& Kirchner, J. T. (1999). Ecstasy (3,4-methylenedioxymethamphetamine): history, neurochemistry, and toxicology. Journal of the American Board of Family Practice, 12, 137-42.

Saunders, N. (1996). Ecstasy e a cultura dance (Marques, T., Trans.). São Paulo S.P.: Publisher Brasil.

Schwab, M., Seyringer, E., Brauer, R. B., Hellinger, A., \& Griese, E. U. (1999). Fatal MDMA intoxication. Lancet, 353, 593-4.

Schwartz, R. H., \& Miller, N. S. (1997). MDMA (ecstasy) and the rave: a review. Pediatrics, $100,705-8$.

Silva, M. T. A., Magalhães, M. P., Barros, R. S., Almeida, S. P., Azevedo, R. B., \& Oliveira, R. C. (1989). Patterns of marihuana smoking among Brasilian students. Drug and Alcohol Dependence, 23, 159-164.

Solowij, N., Hall, W., \& Lee, N. (1992). Recreational MDMA use in Sydney: a profile of 'Ecstacy' users and their experiences with the drug. British Journal of Addiction, 87, 1161-72.

Sondermann, N., \& Kovar, K.-A. (1999). Screening experiments of ecstasy street samples using near infrared spectroscopy. Forensic Science International, 106, 147-156.

Spatt, J., Glawar, B., \& Mamoli, B. (1997). A pure amnestic syndrome after MDMA ("ecstasy") ingestion. Journal of Neurology, Neurosurgery \& Psychiatry, 62, 418-9.

Spector, P. E. (1992). Summated Rating Scale Construction: An Introduction. (2nd ed.): Sage Production Editor.

Spielberger, C. D., Gorsuch, R. L., \& Lushene, R. E. (1979). Inventário de Ansiedade TraçoEstado IDATE (Biaggio, A. M. B.Natalício, L., Trans.). Rio de Janeiro: CEPA.

Vollenweider, F. X., Gamma, A., Liechti, M., \& Huber, T. (1998). Psychological and cardiovascular effects and short-term sequelae of MDMA ("ecstasy") in MDMA-naive healthy volunteers. Neuropsychopharmacology, 19, 241-51.

Whitaker-Azmitia, P. M., \& Aronson, T. A. (1989). "Ecstasy" (MDMA)-induced panic. American Journal of Psychiatry, 146, 119.

Wolff, K., Hay, A. W., Sherlock, K., \& Conner, M. (1995). Contents of "ecstasy". Lancet, 346, 1100-1. 
ANEXO A

\section{INSTITUTO DE PSICOLOGIA DA UNIVERSIDADE DE SÃO PAULO DEPARTAMENTO DE PSICOLOGIA EXPERIMENTAL}

Caro(a) colaborador(a):

Estamos realizando uma pesquisa sobre o uso de "êxtase" em São Paulo. Mesmo que você nunca tenha experimentado sua participação será muito importante.

A sua honestidade e sinceridade nas respostas são fundamentais! Não nos interessa julgar ou dar opiniões sobre o que as pessoas fazem ou deixam de fazer, e não temos absolutamente nenhuma ligação com a polícia ou órgãos de repressão.

Os questionários serão anônimos e sigilosos. Suas respostas serão agrupadas a muitas outras e utilizadas somente em forma de números, estatísticas e comentários gerais.

Muito obrigada por sua participação, e se você souber de outras pessoas que aceitariam responder a este questionário agradecemos muito sua indicação.

Se por qualquer razão você quiser se comunicar conosco sinta-se à vontade, nosso telefone e endereço encontra-se abaixo:

Instituto de Psicologia da Universidade de São Paulo

Departamento de Psicologia Experimental - Sala A6

Av. Prof. Melo Morais, 1721

CEP: 05508-900 - São Paulo - SP

Tel: 8184444 - Ramal 208 - c/ Stella 
CÓDIGO:

1. Com que frequência você vai aos seguintes lugares?

\begin{tabular}{|l|c|c|c|}
\hline & Nunca & Aproximadament & Mais de 1 vez \\
\hline Bares & {$[$ ] } & {$[$ ] } & {$[$ ] } \\
\hline Lugares para dançar & {$[$ ] } & {$[$ ] } & {$[$ ] } \\
\hline Festas & {$[$ ] } & {$[$ ] } & {$[$ ] } \\
\hline Shows & {$[$ ] } & {$[$ ] } & {$[$ ] } \\
\hline Raves & {$[$ ] } & {$[$ ] } & {$[$ ] } \\
\hline Exposições de arte/museus & {$[$ ] } & {$[$ ] } & {$[$ ] } \\
\hline
\end{tabular}

2. Idade: anos.

3. Sexo:

1..[ ]..Homem

2..[ ]..Mulher

4. Opção sexual:

1..[ ]..Heterossexual

2..[ ]..Homossexual

3..[ ]..Bissexual

5. Estado Civil:

1..[ ]..Solteiro(a)

2..[ ]..Casado(a)

3..[ ]..Separado(a)/divorciado(a)

4..[ ]..Outro. Qual?

6. Com quem você mora mais frequentemente?

1..[ ]..Com esposa(o), companheira(o)

2..[ ]..Com parente ( Pai e/ou mãe, avós irmãos...)

3..[ ]..Com amigos

4..[ ]..Sozinho(a)

5..[ ]..Outros.Com quem?

7. Escolaridade:

1..[ ]..Primário completo ou incompleto

2..[ ]..Ginásio completo ou incompleto

3..[ ]..Colegial completo ou incompleto

4..[ ]..Universitário completo ou incompleto

8. Ocupação: (você pode assinalar mais de uma alternativa

1... ]..Estuda

2..[ ]..."Free lancer" ou bicos

3..[ ]..Tem trabalho fixo.

4..[ ]..Está desempregado(a).

5..[ ]..Outros. Qual? 
9. Qual é sua área de trabalho ou estudo?

10. Como você define sua classe sócio-econômica?
1..[ ]..Alta
2..[ ]..Média/Alta
3..[ ]..Média
4..[ ]..Média/Baixa
5..[ ]..Baixa

11. Quanto você recebe por mês (incluindo ajuda familiar ou mesada se for o caso)? reais

12. Aproximadamente, quanto você gasta para sair por semana? Reais.

13. Como você avalia seu relacionamento com seus pais?

1..[ ]..Ruim ou muito ruim

2..[ ]...Mais ou menos

3..[ ]..Bom ou muito bom

14. Você tem alguma religião?

1..[ ]..Sim

2..[ ]..Não

15. Qual a importância que a religião tem em sua vida?

1..[ ]..Muito importante

2..[ ]..Importante

3..[ ]..Pouco importante

4..[ ]..Nada importante

16. Aproximadamente quantas vezes você ficou bêbado(a) no último mês?

1..[ ]..Todos ou quase todos os dias

2..[ ]...Várias vezes por semana

3..[ ]..Algumas vezes no mês

4..[ ]..Uma vez

5..[ ]..Nenhuma vez

17. Quais substâncias da lista abaixo você usou pelo menos uma vez na vida?

(você pode assinalar mais 1de uma alternativa)

1..[ ]..Álcool

2..[ ]..Tabaco/cigarro

3..[ ]..Maconha ou Haxixe

4..[ ]..LSD/Ácido

5..[ ]..Cocaína

6..[ ]..Crack

7..[ ]..Heroína

8..[ ]..Chá de cogumelo ou chá de lírio

9..[ ]..Anfetamina (remédio para emagrecer ou ficar acordado)

10..[ ]..Tranquilizantes (remédio para dormir ex.: diazepan, valium, dormonid...)

11..[ ]..Lança perfume, cola ou solventes(ex: benzina, éter...)

12..[ ]..Outras drogas? Quais? 
18. Quais substâncias da lista abaixo você usou, pelo menos uma vez, durante o último mês?

(você pode assinalar mais 1de uma alternativa)

1...[ ]..Álcool

2..[ ]..Tabaco/cigarro

3..[ ]..Maconha ou Haxixe

4..[ ]..LSD/Ácido

5..[ ]..Cocaína

6..[ ]..Crack

7..[ ]...Heroína

8..[ ]..Chá de cogumelo ou chá de lírio

9..[ ]..Anfetamina (remédio para emagrecer ou ficar acordado)

10..[ ]..Tranquilizantes (remédio para dormir ex.: diazepan, valium, dormonid...)

11..[ ]..Lança perfume, cola ou solventes(ex: benzina, éter...)

12..[ ]..Outras drogas? Quais?

19. Você já pensou em parar de usar alguma droga?

1..[ ]..Não uso drogas.

2..[ ]..Não, nunca pensei em parar de usar nenhuma droga.

3..[ ]..Sim, já pensei. Qual(is) drogas você já pensou em parar de usar?

20. Você acha que tomar êxtase pode trazer problemas para quem usa?

(Você pode escolher mais de uma alternativa)

1..[ ]..Não pode trazer problemas

2..[ ]..Sim, porque é ilegal

3..[ ]..Sim, porque no dia seguinte a pessoa se sente mal

4..[ ]..Sim, porque pode gerar dependência

5..[ ]..Sim, porque pode trazer problemas psicológicos

6..[ ]..Sim, porque tem efeitos imprevisíveis

7... [ ]..Sim, porque o comprimido pode ser adulterado

8..[ ]..Sim, porque cria problemas familiares

9..[ ]..Sim, porque pode criar problemas mentais

10..[ ]..Sim, quando seus amigos não usam

11..[ ]..Sim, porque faz mal para a saúde.

12..[ ]..Outros? Quais?

21. Quantos de seus amigos tomam êxtase?

1..[ ]..A maioria ou todos

2..[ ]...Mais ou menos a metade

3..[ ]..Alguns

4..[ ]..Nenhum

\section{OBS: A questão número 22 só constou do questionário para não usuários}

22. Porque você nunca experimentou Êxtase?

1..[ ]..Tive medo de experimentar

2..[ ]..Não estava bem fisicamente

3..[ ]..Não estava bem psicologicamente

4..[ ]..Não estava com a companhia adequada

5..[ ] ]..Tinha compromissos no dia seguinte

6..[ ]..Tinha usado outras drogas e não quis misturar

7..[ ]...Nunca tive a oportunidade

8..[ ]..Outros: 
23. Quando você toma Êxtase:

1..[ ]...Não é importante saber exatamente a composição do que estou tomando.

2..[ ]..Prefiro saber o que estou tomando, mas se não sei tomo do mesmo jeito.

3..[ ]..Se não sei a composição do comprimido, prefiro não tomá-lo.

24. Quantos anos você tinha quando usou êxtase pela primeira vez? anos.

25. Quando você usa êxtase, geralmente, quantos comprimidos toma ao todo?

1.[ ]..Menos de um comprimido.

2.[ ]..Um comprimido.

3. [ ]..Dois comprimidos.

4.[ ]..Mais de dois comprimidos.

26. Nos últimos 3 meses, aproximadamente quantas vezes você tomou êxtase?

1.[ ]..Não tomei nos últimos 3 meses.

2.[ ]..Tomei até no máximo uma vez por mês.

3.[ ]..Tomei até no máximo 1 vez por semana.

4.[ ]..Tomei mais de uma vez por semana.

27. No último mês, quantas vezes você tomou êxtase?

1.[ ]..Não tomei no último mês.

2.[ ]..Tomei uma vez.

3.[ ]..Tomei entre 2 e 4 vezes.

4.[ ]..Tomei entre 5 e 8 vezes.

5.[ ]..Tomei mais de 8 vezes.

28. Normalmente você toma êxtase:

1..[ ]..Apenas no final de semana ou férias

2..[ ]..Durante a semana

3..[ ]..Em qualquer dia da semana

29. Com quem você toma êxtase mais frequentemente? (você pode assinalar mais de uma alternativa)

1..[ ]..Sozinha

2..[ ]..Com mais uma pessoa.

3..[ ]..Com várias pessoas.

30. Onde você costuma tomar êxtase? (você pode assinalar mais de uma alternativa)

1..[ ]...Em casa ou na casa de amigos

2..[ ]..Em raves

3..[ ]..Em lugares para dançar

4... [ ]..Em bares

5... [ ]..Na rua

6..[ ]...Em festas

7..[ ]..Outros. Onde? 
31. Da lista abaixo assinale como você se sente durante o efeito do êxtase?

(você pode assinalar mais de uma alternativa)

\author{
1..[ ]..Eufórica \\ 2..[ ]..Feliz \\ 3..[ ]..Calma \\ 4..[ ]..Mais próxima das outras pessoas \\ 5... ] ]..Amorosa \\ 6..[ ]..Com tesão \\ 7..[ ]...Emotiva \\ 8..[ ]..Com energia \\ 9..[ ]..Com pensamento claro \\ 10..[ ]..Alerta \\ 11..[ ]..Atenta \\ 12..[ ]..Falante \\ 13..[ ]..Despreocupada \\ 14..[ ]..Em paz \\ 15..[ ]..Íntima das pessoas \\ 16..[ ]..Sexual \\ 17..[ ]..Sensual \\ 18..[ ]..Auto confiante \\ 19..[ ]..Com a auto estima aumentada \\ 20..[ ]..Segura \\ 21..[ ]..Mente aberta \\ 22..[ ]...Aberta ao ambiente \\ 23..[ ]..Fico à vontade \\ 24..[ ]..Voltada para o aqui e agora \\ 25..[ ]..Penso no passado ou futuro \\ 26..[ ]..Tenho "insights" \\ 27..[ ]..Iluminada \\ 28..[ ]..Espiritual \\ 29..[ ]..Agitada \\ 30..[ ]..Nervosa \\ 31..[ ]..Preocupada \\ 32..[ ]..Descoordenada \\ 33..[ ]..Preocupada com o que pensam de mim \\ 34..[ ]..Com pensamentos estranhos \\ 35..[ ]..Inferior \\ 36..[ ]..Insegura \\ 37..[ ]..Isolada \\ 38..[ ]..Tensa \\ 39..[ ]..Com medo \\ 40..[ ]..Paranóica \\ 41..[ ]..Com raiva \\ 42..[ ]..Solitária
}

43..[ ]..Triste

44..[ ] ]..Com tensão no maxilar

45..[ ]..Rangendo os dentes

46..[ ]..Com a boca seca

47..[ ] ]..Suando nas palmas das mãos

48..[ ]..Tenho suor generalizado

49..[ ]..Com ondas de frio ou calor

50..[ ]..Com o coração acelerado

51..[ ]..Tenho palpitações

52..[ ]...Com a cabeça latejando

53..[ ]..Com dores de cabeça

54..[ ]..Com tontura

55..[ ] ...Com tremores

56..[ ]..Com formigamentos

57..[ ]..Com náusea

58..[ ]..Tenho vômitos

59..[ ]..Com dores musculares

60..[ ]..Tenho espasmos ou convulsões

61..[ ]..Com vontade de urinar

62..[ ]..Com a visão turva

63..[ ]..Com pupilas dilatadas

64..[ ]..Com tato estimulado

65..[ ]..Tenho alucinações visuais

66..[ ] ]..Tenho alucinações auditivas

67..[ ]..Desorientado

68..[ ]..Perco a noção do real

69..[ ]..Com a percepção aguçada

70..[ ]...Noção de tempo alterada

71..[ ]..Ansiosa

72..[ ]..Em pânico

73..[ ]...Mentalmente instável

74..[ ]..Confusa

75..[ ] ]..Com dificuldade de concentração

76..[ ] ]..Sem sono

77..[ ]..Sem apetite

78..[ ]..Irritável

79..[ ]..Deprimida

80..[ ]..Apática

81..[ ]..Sem energia

82..[ ].. Outros? Quais? 
32. Enquanto o êxtase está fazendo efeito você costuma usar alguma outra substância da lista abaixo? (você pode assinalar mais de uma alternativa)

1..[ ]..Não costumo usar nenhuma outra droga

2..[ ]..Sim, Álcool (Qualquer bebida alcoólica)

3..[ ]..Sim, Cigarro

4..[ ]..Sim, Cocaína/crack

5..[ ]..Sim, Anfetamina

6..[ ]..Sim, Ácido/LSD

8..[ ]..Sim, Maconha

9..[ ]..Sim, Outras. Quais?

33. Você já pensou em parar de usar Êxtase?

1..[ ]..Não uso mais êxtase.

2..[ ]..Sim, já pensei em parar.

3..[ ]..Não, nunca pensei nisso.

34. De quem você compra êxtase? (você pode assinalar mais de uma alternativa)

1..[ ]..Não compro.

2..[ ]..De amigos ou conhecidos.

3..[ ]..De alguém que faz tráfico.

4..[ ]..Outros:

35. Onde você adquire êxtase? (você pode assinalar mais de uma alternativa)

1..[ ]..Em bares ou lugares para dançar

2..[ ]...Na rua ou ponto de tráfico

3..[ ]..Em raves

4..[ ]..Em festas

5..[ ]..Outros. Quais?

36. Quanto custa cada comprimido?

1..[ ]..Não sei

Aproximadamente Reais

37. Para você, os efeitos do êxtase são, na maioria das vezes:

1..[ ]..Positivos

2..[ ]..Positivos e negativos

3..[ ]..Negativos

38. Quais são as principais razões para você usar êxtase?(assinale até 3 alternativas)

1..[ ]..Para relaxar

2..[ ]..Para dançar

3..[ ]..Para ficar mais desinibido

4..[ ]..Para se sentir mais feliz

5..[ ]..Para fugir da realidade e/ou esquecer problemas

6..[ ]..Para se sentir melhor com outras pessoas

7..[ ]..Para transar melhor

8..[ ]..Para estimular a criatividade

9..[ ]..Para estimular os sentidos

10..[ ]..Outra(s). Qual(is)? 
ANEXO B.3

IDATE - T

Leia cada pergunta e faça um círculo em redor do número à direita que melhor indicar como você geralmente se sente. Não gaste muito tempo numa única afirmação, mas tente dar a resposta que mais se aproximar de como você se sente geralmente.

\section{AVALIAÇÃO}

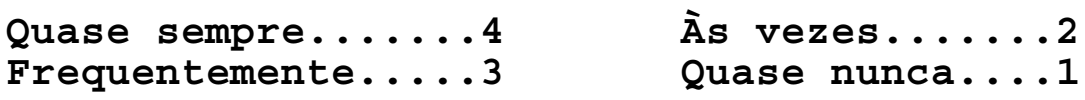

1. Sinto-me bem ........................1 2 3

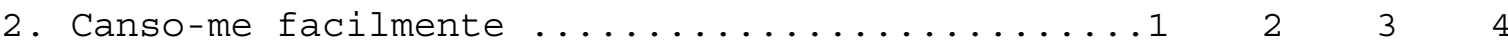

3. Tenho vontade de chorar ................................. 24

4. Gostaria de poder ser tão feliz quanto os outros parecem ser.............. 2 34

5. Perco oportunidades porque não consigo tomar decisões rapidamente .......... $2 \quad 3 \quad 34$

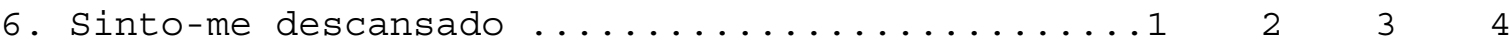

7. Sinto-me calmo(a), ponderado (a) e senhor $(a)$ de mim mesmo ................. 2 34

8. Sinto que as dificuldades estão se acumulando de tal forma que não as consigo resolver ...... $24 \quad 3 \quad 4$

9. Preocupo-me demais com coisas sem importância.1 $\quad 2 \quad 3 \quad 34$

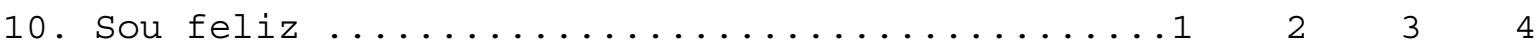

11. Deixo-me afetar muito pelas coisas .......... 2434

12. Não tenho muita confiança em mim mesmo(a) ....1 $2 \quad 3 \quad 4$

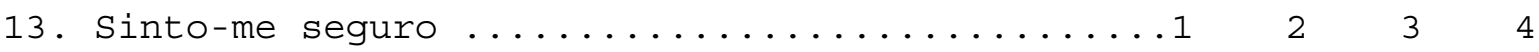

14. Evito ter que enfrentar crises ou problemas ...1 $2 \quad 2 \quad 3 \quad 4$

15. Sinto-me deprimido ..................... 2434

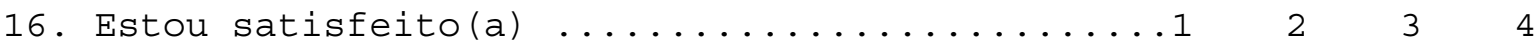

17. Às vezes idéias sem importância me entram na cabeça e ficam-me preocupando ............ $2 \quad 3 \quad 3$

18. Levo os desapontamentos tão a sério que não consigo tirá-los da cabeça ................ 2 34

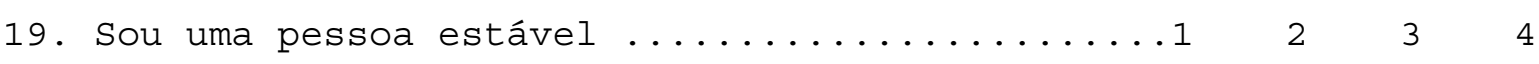

20. Fico tenso(a) e perturbado(a) quando penso em meus problemas do momento ............... $2 \quad 3 \quad 4$ 


\section{BECK INVENTORY}

Este questionário consiste em 21 grupos de afirmações. Depois de ler cuidadosamente cada grupo, faça um círculo em torno do número $(0,1,2$, ou 3$)$ próximo à afirmação, em cada grupo, que descreve melhor a maneira que você tem se sentido na última semana, incluindo hoje. Se várias afirmações num grupo parecerem se aplicar igualmente bem, faça um círculo em cada uma. Tome o cuidado de ler todas as afirmações, em cada grupo, antes de fazer a sua escolha.

1. 0 [ ] Não me sinto triste.

1 [ ] Eu me sinto triste.

2 [ ] Estou sempre triste e não consigo sair disso.

3 [ ] Estou tão triste ou infeliz que não consigo suportar.

2. 0 [ ] Não estou especialmente desanimado(a) quanto ao futuro.

1 [ ] Eu me sinto desanimado(a) quanto ao futuro.

2 [ ] Acho que nada tenho a esperar.

3 [ ] Acho o futuro sem esperança e tenho a impressão de que as coisas não podem melhorar.

3. 0 [ ] Não me sinto um fracasso.

1 [ ] Acho que fracassei mais do que uma pessoa comum.

2 [ ] Quando olho para trás, na minha vida, tudo que posso ver é um monte de fracassos.

3 [ ] Acho que, como pessoa, sou um completo fracasso.

4. 0 [ ] Tenho tanto prazer em tudo como antes.

1 [ ] Não sinto mais prazer nas coisas como antes.

2 [ ] Não encontro um prazer real em mais nada.

3 [ ] Estou insatisfeito(a) ou aborrecido(a) com tudo.

5. 0 [ ] Não me sinto especialmente culpado(a).

1 [ ] Eu me sinto culpado(a) grande parte do tempo.

2 [ ] Eu me sinto culpado(a) na maior parte do tempo.

3 [ ] Eu me sinto sempre culpado(a).

6. $\quad 0$ [ ] Não acho que esteja sendo punido(a).

1 [ ] Acho que posso ser punido(a).

2 [ ] Creio que vou ser punido(a).

3 [ ] Acho que estou sendo punido(a).

7. 0 [ ] Não me sinto decepcionado(a) comigo mesmo.

1 [ ] Estou decepcionado(a) comigo mesmo.

2 [ ] Estou enojado(a) de mim.

3 [ ] Eu me odeio.

8. 0 [ ] Não me sinto de qualquer modo pior que os outros.

1 [ ] Sou crítico(a) em relação a mim por minhas fraquezas ou erros.

2 [ ] Eu me culpo sempre por minhas falhas.

3 [ ] Eu me culpo por tudo de mal que acontece.

9. $\quad 0$ [ ] Não tenho quaisquer idéias de me matar.

1 [ ] Tenho idéias de me matar, mas não as executaria.

2 [ ] Gostaria de me matar.

3 [ ] Eu me mataria se tivesse oportunidade.

10. 0 [ ] Não choro mais que o habitual.

1 [ ] Choro mais agora do que costumava.

2 [ ] Agora, choro o tempo todo.

3 [ ] Costumava ser capaz de chorar, mas agora não consigo mesmo que o queira. 
11. 0 [ ] Não sou mais irritado(a) agora do que já fui.

1 [ ] Fico aborrecido(a) ou irritado(a) mais facilmente do que costumava.

2 [ ] Agora eu me sinto irritado(a) o tempo todo.

3 [ ] Não me irrito mais com coisas que costumavam me irritar.

12. 0 [ ] Não perdi o interesse pelas outras pessoas.

1 [ ] Estou menos Interessado(a) pelas outras pessoas do que costumava estar.

2 [ ] Perdi a maior parte do meu interesse pelas outras pessoas.

3 [ ] Perdi todo o interesse pelas outras pessoas.

13. 0 [ ] Tomo decisões tão bem quanto antes.

1 [ ] Adio as tomadas de decisões mais do que costumava.

2 [ ] Tenho mais dificuldade de tomar decisões do que antes.

3 [ ] Absolutamente não consigo mais tomar decisões.

14. 0 [ ] Não acho que de qualquer modo pareço pior do que antes.

1 [ ] Estou preocupado(a) em estar parecendo velho(a) ou sem atrativo.

2 [ ] Acho que há mudanças permanentes na minha aparência, que me fazem parecer sem atrativos.

3 [ ] Acredito que pareço feio(a).

15. 0 [ ] Posso trabalhar tão bem quanto antes.

1 [ ] É preciso algum um esforço extra para fazer alguma coisa.

2 [ ] Tenho que me esforçar muito para fazer alguma coisa.

3 [ ] Não consigo mais fazer qualquer trabalho.

16. 0 [ ] Consigo dormir tão bem como o habitual.

1 [ ] Não durmo tão bem como costumava.

2 [ ] Acordo uma a duas horas mais cedo do que habitualmente e acho difícil voltar a dormir.

3 [ ] Acordo várias horas mais cedo do que costumava e não consigo voltar a dormir.

17. 0 [ ] Não fico mais cansado(a) do que o habitual.

1 [ ] Fico cansado(a) mais facilmente do que costumava.

2 [ ] Fico cansado(a) em fazer qualquer coisa.

3 [ ] Estou cansado(a) demais para fazer qualquer coisa.

18. 0 [ ] O meu apetite não está pior do que o habitual.

1 [ ] Meu apetite não é tão bom como costumava ser.

2 [ ] Meu apetite é muito pior agora.

3 [ ] Absolutamente não tenho mais nenhum apetite.

19. 0 [ ] Não tenho perdido muito peso se é que perdi algum recentemente.

1 [ ] Perdi mais do que $2,5 \mathrm{Kg}$.

2 [ ] Perdi mais do que $5,0 \mathrm{Kg}$.

3 [ ] Perdi mais do que $7 \mathrm{Kg}$.

Obs: Estou tentando perder peso de propósito, comendo menos: SIM ( ) NÃO ( )

20. 0 [ ] Não estou mais preocupado(a) com a minha saúde do que o habitual.

1 [ ] Estou preocupado(a) com problemas físicos, tais como dores, indisposição do estômago ou prisão de ventre.

2 [ ] Estou muito preocupado(a) com problemas físicos e é difícil pensar em outra coisa.

3 [ ] Estou tão preocupado(a) com meus problemas físicos que não consigo pensar em qualquer outra coisa

21. 0 [ ] Não notei qualquer mudança recente no meu interesse por sexo.

1 [ ] Estou menos interessado(a) por sexo que costumava.

2 [ ] Estou muito menos interessado(a) por sexo agora.

3 [ ] Perdi completamente o interesse por sexo. 
Instruções: As pessoas divergem nas formas em que agem e pensam em diferentes situações. Isto é um teste para avaliar algumas das maneiras que você age ou pensa. Leia cada afirmação e preencha o círculo apropriado no lado direito da página. Não gaste muito tempo em cada afirmação. Responda rápida e honestamente.

\begin{tabular}{|c|c|c|c|c|}
\hline & $\begin{array}{l}\text { Rara- } \\
\text { mente ou } \\
\text { Nunca }\end{array}$ & $\begin{array}{l}\text { De vez } \\
\text { em } \\
\text { Quando }\end{array}$ & $\begin{array}{l}\text { Com } \\
\text { Freqüên } \\
\text {-cia }\end{array}$ & $\begin{array}{l}\text { Quase } \\
\text { sempre/ } \\
\text { sempre }\end{array}$ \\
\hline 1. Eu planejo tarefas cuidadosamente & $\mathrm{O}$ & $\mathrm{O}$ & $\mathrm{O}$ & $\mathrm{O}$ \\
\hline 2. Eu faço coisas sem pensar & $\mathrm{O}$ & $\mathrm{O}$ & $\mathrm{O}$ & $\mathrm{O}$ \\
\hline 3. Eu sou despreocupado (confio na sorte - "desencanado") & $\mathrm{O}$ & $\mathrm{O}$ & $\mathrm{O}$ & $\mathrm{O}$ \\
\hline 4. Eu tenho pensamentos rápidos & $\mathrm{O}$ & $\mathrm{O}$ & $\mathrm{O}$ & $\mathrm{O}$ \\
\hline 5. Eu planejo viagens com bastante antecedência & $\mathrm{O}$ & $\mathrm{O}$ & $\mathrm{O}$ & $\mathrm{O}$ \\
\hline 6. Eu sou controlado & $\mathrm{O}$ & $\mathrm{O}$ & $\mathrm{O}$ & $\mathrm{O}$ \\
\hline 7. Eu me concentro facilmente & $\mathrm{O}$ & $\mathrm{O}$ & $\mathrm{O}$ & $\mathrm{O}$ \\
\hline 8. Eu poupo regularmente & $\mathrm{O}$ & $\mathrm{O}$ & $\mathrm{O}$ & $\mathrm{O}$ \\
\hline 9. Eu acho difícil ficar sentado sem mexer por longos períodos de tempo & $\mathrm{O}$ & $\mathrm{O}$ & $\mathrm{O}$ & $\mathrm{O}$ \\
\hline 10. Eu sou um pensador cuidadoso & $\mathrm{O}$ & $\mathrm{O}$ & $\mathrm{O}$ & $\mathrm{O}$ \\
\hline 11. Eu faço planos para um trabalho seguro & $\mathrm{O}$ & $\mathrm{O}$ & $\mathrm{O}$ & $\mathrm{O}$ \\
\hline 12. Eu falo coisas sem pensar & $\mathrm{O}$ & $\mathrm{O}$ & $\mathrm{O}$ & $\mathrm{O}$ \\
\hline 13. Eu gosto de pensar em problemas complexos & $\mathrm{O}$ & $\mathrm{O}$ & $\mathrm{O}$ & $\mathrm{O}$ \\
\hline 14. Eu troco de trabalho & $\mathrm{O}$ & $\mathrm{O}$ & $\mathrm{O}$ & $\mathrm{O}$ \\
\hline 15. Eu ajo por impulso & $\mathrm{O}$ & $\mathrm{O}$ & $\mathrm{O}$ & $\mathrm{O}$ \\
\hline $\begin{array}{l}\text { 16. Eu fico facilmente entediado quando estou resolvendo problemas } \\
\text { mentalmente }\end{array}$ & 0 & 0 & 0 & 0 \\
\hline 17. Eu faço “chek-up” médico e odontológico regularmente & $\mathrm{O}$ & $\mathrm{O}$ & $\mathrm{O}$ & $\mathrm{O}$ \\
\hline 18. Eu atuo irrefletidamente levado pelas circuntâncias & $\mathrm{O}$ & $\mathrm{O}$ & $\mathrm{O}$ & $\mathrm{O}$ \\
\hline 19. Eu sou um pensador equilibrado & $\mathrm{O}$ & $\mathrm{O}$ & $\mathrm{O}$ & $\mathrm{O}$ \\
\hline 20. Eu troco de moradia & $\mathrm{O}$ & $\mathrm{O}$ & $\mathrm{O}$ & $\mathrm{O}$ \\
\hline 21. Eu compro coisas por impulso & $\mathrm{O}$ & $\mathrm{O}$ & $\mathrm{O}$ & $\mathrm{O}$ \\
\hline 22. Eu acabo o que começo & $\mathrm{O}$ & $\mathrm{O}$ & $\mathrm{O}$ & $\mathrm{O}$ \\
\hline 23. Eu ando e me mexo rápido & $\mathrm{O}$ & $\mathrm{O}$ & $\mathrm{O}$ & $\mathrm{O}$ \\
\hline 24. Eu resolvo problemas por tentativa e erro & $\mathrm{O}$ & $\mathrm{O}$ & $\mathrm{O}$ & $\mathrm{O}$ \\
\hline 25. Eu gasto ou compro a prestação mais do que ganho & $\mathrm{O}$ & $\mathrm{O}$ & $\mathrm{O}$ & $\mathrm{O}$ \\
\hline 26. Eu falo rápido & $\mathrm{O}$ & $\mathrm{O}$ & $\mathrm{O}$ & $\mathrm{O}$ \\
\hline 27. Eu tenho idéias fora de contexto quando estou pensando & $\mathrm{O}$ & $\mathrm{O}$ & 0 & $\mathrm{O}$ \\
\hline 28. Eu estou mais interessado no presente do que no futuro & $\mathrm{O}$ & $\mathrm{O}$ & $\mathrm{O}$ & $\mathrm{O}$ \\
\hline 29. Eu fico inquieto em palestras ou conversas & $\mathrm{O}$ & $\mathrm{O}$ & $\mathrm{O}$ & $\mathrm{O}$ \\
\hline 30. Eu faço planos para o futuro & $\mathrm{O}$ & 0 & 0 & 0 \\
\hline
\end{tabular}

SE VOCÊ QUISER FAZER ALGUM COMENTÁRIO, USE O VERSO DESTA FOLHA MUITO OBRIGADA POR SUA PARTICIPAÇÃO! 
ANEXO B.4

\section{Entrevista final}

Código:

Data:

Local:

Que tipo(s) de música prefere

2. Tatoo 1..[ ]..Não

2..[ ]..Sim. Quantas?

3. Piercing..1..[ ]..Não

2..[ ]..Sim. Quantos?

Êxtase quantas vezes na vida?

Frequência atual:

Observações: 


\section{INFORMAÇÕES DE SEGURANÇA PARA AQUELES QUE UTILIZAM OU VENHAM A UTILIZAR “ÊXTASE”:}

1. Beber líquido com frequência, mas sem exagero.

2. Beber não apenas água, mas também sucos de frutas ou bebidas que possam repor as perdas eletrolíticas, bebidas com açúcar ou sais minerais.

3. Fazer um intervalo entre o consumo de comprimidos de MDMA de pelo menosseishoras.

4. Quando em atividade física, na pista de dança, por exemplo, ausentar-se do local algumas vezes durante a noite para relaxar. A maioria dos "clubes” têm atualmente um lugar chamado “Chill out”, onde a música é mais baixa e há ventilação e lugares confortáveis para sentar e descansar.

5. Contar a quem o acompanha exatamente o que usou, pois se precisar de auxílio médico em pronto-socorro, essas informações serão muito importantes para uma intervenção clínica adequada.

6. Se for possível, indagar sobre os efeitos do comprimido que vai usar a quem já o utilizou, já que a composição do comprimido é sempre incerta e pode ter efeitos imprevisíveis.

7. Evitar ao máximo a mistura de "êxtase" com outras drogas psicotrópicas, em especial álcool, solventes voláteis, anfetamina, cocaína e crack.

8. Não utilizar "êxtase” como medicação para depressão posterior ao uso.

9. Fazer intervalos entre episódios de consumo, pois quanto maiores menor a possibilidade de problemas advindos do uso. 